$$
\text { THE }
$$

\title{
5TAMP-FIENDS $5^{\circ}$
}
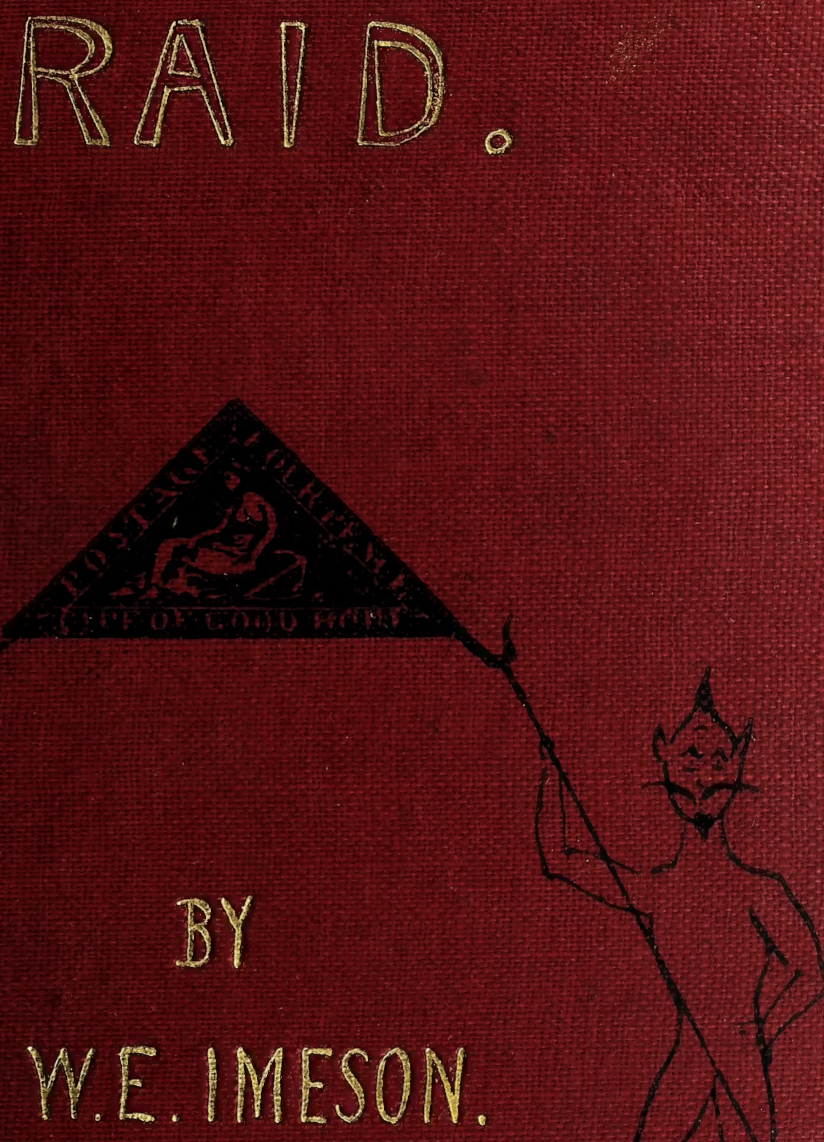



\section{Gift of GEORGE T TURNER}






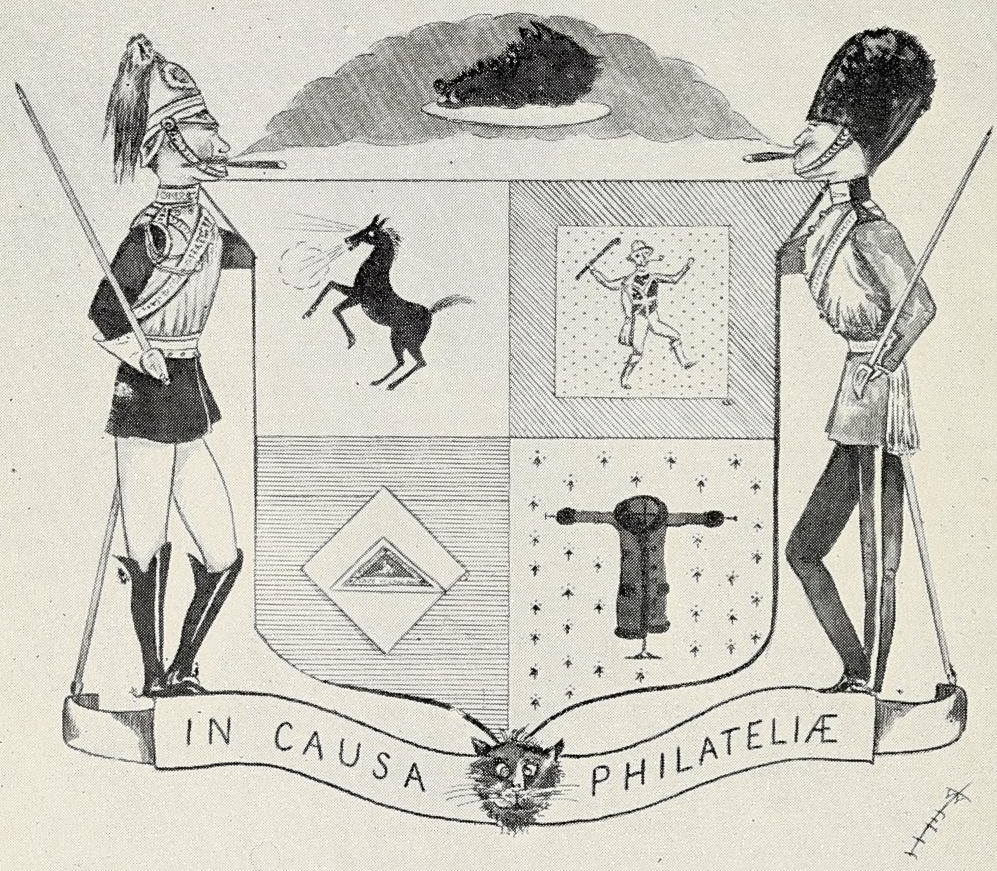

THE WYLIE - JONES COMBINE

ARMS OF ASSUMPTION \& PRETENSION

CREST A BOAR'S HEAD ERASED, "smoked" " 'drshed".

ARGENT, A HORSE RAMPANT SABLE. (VERT (BETHNAL), ON A GOLD (OR)FIELD) $\left\{\begin{array}{l}\text { AZURE:ON A LOZENGE ARGENT A A"WLD BOER" TRIPPANT, VESTED GULES. } \\ \text { ARGENT AND AZURE. }\end{array}\right.$ TRIANGULAR "CAPE" SANGUINE. ERMINE, A FUR-COAT SABLE. SUPPORTERS, A HORSE GUARD AZURE AND AN “HONOURABLE" CULES. 


\title{
THE
}

\section{STAMP-FIENDS RAID \\ (IN PHILATELIA'S CAUSE).}

\section{A PHILATELIC PHANTASY.}

\author{
W. $\| a^{m}$
Wy
IIMESON.
}

WITH PICTORIAL ABSURDITIES

BY

THE AUTHOR.

London:

HORACE COX,

WINDSOR HOUSE, BREAM'S BUILDINGS, E.C.

1903. 



\section{AUTHOR'S NOTE.}

THIS BOOK is intended for the general reader, as well as for those who are interested in the various special subjects introduced. A key to the many personal references, terms, abbreviations, \&c., will be found at the end of the volume. It is hoped that the explanations and definitions contained in this Glossary will, though necessarily brief, enable all readers to follow the story with interest. 



\section{DED ICATI $0 \mathrm{~N}$.}

\section{To ALLAN OCTAVIAN HUME, C.B., \&c.}

To thee, old friend, whose heart Hope e'er keeps young,

(For Hope ne'er dies when Time hath spared life's Spring)

I would that, in the medley strange I sing,

A worthier song were sung.

For her, "The brightest gem in Britain's crown "

(Whose lustre oft is dimmed in famine's shade), Thy voice is ever raised (as once thy blade)

With those who wrong disown.

$$
\text { * } \quad * \quad * \quad * \quad * \quad *
$$

Rare birds of plumage gay from Ind's fair land, Strange horns of big game, from far hill and plain, Mark the "Collector" true-the Nation's gain The task is of thy hand.

She whom thou servest now, with single heart, With hand as tireless and with eye as true, Might envy rouse that all thy service due To her should be, nor part. 
The Goddess Flora brooks no rival claim,

Yet proud were I, and proud methinks were She

Whose book I write, upon this page to see

Inscribed thy veteran name.

Set to the plough, not thine the hand to pause,

Yet, tho' apart our furrows wide may be,

Fain would I ask thy kindly sympathy

In Philatelia's Cause. 


\section{APOLOGIA PHILATELIE.}

Goddess and Patron Saint, grant thou the prayer Of one a humble pilgrim at thy shrine;

While crowns thine altar many an offering rare, Tho' poor the gift, with favour look on mine.

Haply the lighter mood I find thee in, Would Science quit thy Temple for awhile, Happy the augury, I perchance might win The rare indulgence of thy passing smile.

Must what We love the slave of Science be? For too much science life were far too short, Yet, tho' the cap and bells I don, for me The Prince of Pastimes means no idle sport.

Many a vigil I have kept for thee, Thy world-wide message much to me doth say, Goddess, my love-born service 'boldens me E'en this crude pæan at thy feet to lay, 
I that have known, yet knew not how to pass, Those lingering hours, when hope doth faint remain, Thine aid, to speed Time's laggard hour-glass,

Have sought, and, Goddess, ne'er have sought in vain.

I, as of old, thy loyal knight would be,

I that have passed thro' every grade and stage,

Proud if perchance the call should come to me

To rise, and in thy Cause take up the "gauge."

In this, my lettered gift, no line is writ

To slight the rites of pure Philately, Yet would I tender, for so rude a skit,

Fair Philatelia, my Apology. 


\section{TO THE READER.}

(Critical and Otherwise.)

Dear reader (would I style thee dear, If but to show I hold not cheap Thy good opinion, which I were Happy to win and proud to keep), Pass thou a kind, indulgent eye O'er my rude screed — or pass it by.

May Philatelia calm for me Stern Science's rebuke, or rage. (To her my full Apology Thou'lt find on the preceding page). Is it too much to ask of thee That thou wilt prove as kind as She?

Naught writ in malice here thou'lt find, 'Twere ill if fell from One of Us Aught to give pain or words unkind: Written in good part--take it thus, Or lightly wield the critic's staff "Gainst one who scatters harmless " chaff." 
Not I alone, but friend Paul Jones,

Whose words, with mine, this skit records, Were grieved indeed did "broken bones"

Follow well-meant if misjudged words, And trust we that if here be found Aught to amuse-there's naught to wound.

As poets proper neither shines,

Yet we'd that night to speak in verse, No time to polish up our "lines"

(Take them for better or for worse) ;

No time a phrase to choose or pick, Nor to consult a rhyming dic.

There's many styles of poetry,

Each poet sounds his special notes, The poet in reality,

The "poet" (like us two) in quotes.

Please pass our rhymes as rude or neat, Also the tripping of our "feet."

It sounds a mean thing, p'r'aps, to say

That all the better lines are mme (Just now from town is Jones away)

But Paul as poet does not shine.

Yet choose between-your choice lies here-

A private " poet" and privateer.

He who the cap would wish to fit

The head for which it is not meant, May find, whilst thus misfitting it, His time (and charity) misspent. 
Tho' I in protest raise no voice,

You pay your money-take your choice.

Some in this story may perceive

An awful lack of moral tone,

But, serious reader, don't believe

All that you read-nor half alone.

For here you see, and at their worst,

Two Stamp-Fiends-'neath a spell accurst.

O captious critic! an' thou wilt

The voyage take-prepare for dumps,

Our craft's for shallow waters built,

Her cargo's light, and, tho' she bumps

On "rocky" rhymes, your squalls won't stop.

Our cruise-till we our anchor drop.

* * * * * * *

My Publisher I called to see.

You've read, p'r'aps, that "Bardbbas was

A__ " Well, with that I can't agree;

That quip as truth no more I'll pass.

With kindness only did I meet.

He spoke first of the "awful heat."

How was I feeling? - it was bad

For too long in the sun to be, And-had I ever sun-stroke had?

Or-was it in the family?

It's little pleasantries like these

That help to put one at one's ease. 
And then, "You've written here," said he, "A screed whose length had Homer shamed.

It's longer than The Odyssey!"

Virgil and Horace, too, he named.

"But, sir," said I, with dignity,

"Mine's quantity and quality!

“ I'll ne'er to Horace tune my songIn nobler strains I strive to write; Gross libels to his muse belong,

And such as I would ne'er indite.

Yet why should I poor Horace box?--

I'm here to tackle Horace Cox !

« Those minor, ancient bards, you'll own,

We modern poets far outshine,

For who admires their ponderous tone?

They never wrote such lines as mine!"

At last-at last-I'd won my due,

For said my Publisher, "That's true!

"I've never read such verse before."

My triumph I could scarce contain.

He added yet one tribute more-

"I'll never read such verse again!"

This man could genius understand;

I rose, and seized and shook his hand.

And then I bared my heart, and this

He, as a good judge, saw was good,

For in return he showed me his,

And that was neither stone nor wood. 
I speak with confidence, for, lo!

I touched his heart, so ought to know.

I told him all : I whispered why My book-and soon-must published be.

E'en Publishers have hearts, for I

At once aroused his sympathy ;

He did not hesitate one bit,

But said, "Young man, that settles it!"

What did I whisper? Reader, fie!

You should not such a question ask.

No secrets, tho', have you and I.

To tell you all shall be my task ;

And I will tell you all-anon.

So you read on, and on, and on ! 



\section{CHIEF CHARACTERS.}

Will Wylie (Captain H.A.C.), the raconteur.-An incorruptible journalist and philatelist, who has fallen among thieves.

Captain Paul Jones, the Philatelic Privateer (of "The Blues"). - Will Wylie's special chum (and evil genius), a Prince in philately, a Machiavelli in diplomacy, a Napoleon in strategy, and a "poet" (in quotes).

Pedlar Jim ("the Cape boy").-A long suffering and short-sighted atom, with only the ghost of a part.

Big Birdcage Ben (Chief of the "Ole Clo" Contingent). -One quite at home on most subjects, but much at sea on Stamps.

Percy Pennyweight (Ex Stamp Auctioneer).-A soldier of (bad) fortune, reduced to the (cab) ranks, with a rare badge (plate) No.

"Tough" Tucker.-Mine host of "The Pedlars' Arms." 
Phil Philpot, of “The Boar's Head."-A host in himself.

Bill Bludgeon ("The Boer o' Bethnal Green”).-The Hereward of Cockneydom, a born leader and warcritic par excellence, and the holder of weird and wonderful War Stamps.

Liliuokalani ("The Tily o' Killarney"), Ex-Queen of the Sandwich Islands.-A lady with a Philatelic mission - from far Hawaii.

Philatelic Flo (a charming serio-comic).-Also with a mission-in keeping with her stage name.

Pauline (the peerless), the one and only sister of "The Philatelic Privateer." - A lady of rare appearance -and many parts. 


\section{THREADS OF THE YARN.}

I. In the Grip o' the "Flu" " $\quad \ldots \quad$... $\quad$...page 1

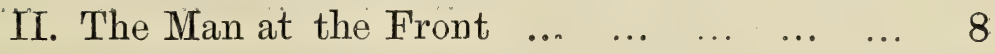



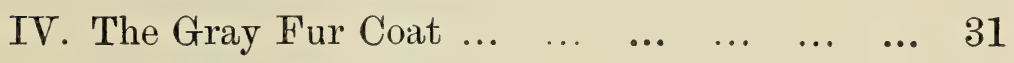

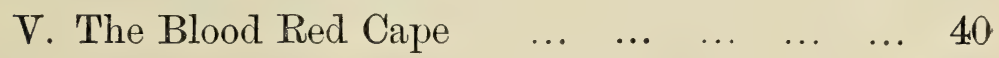

VI. A Bargain Hunter $\ldots \begin{array}{lllllll}\ldots & \ldots & \ldots & \ldots & \ldots & 51\end{array}$

VII. An Unholy Alliance... $\ldots \begin{array}{llllll}\ldots & \ldots & \ldots & \ldots & \ldots & 58\end{array}$

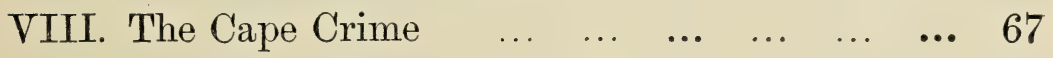



X. Stamp-Fiends Two

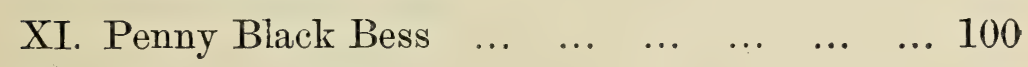

$\begin{array}{llllllll}\text { XII. V.R. Penny Black } & \ldots & \ldots & \ldots & \ldots & \ldots & \ldots & 109\end{array}$

$\begin{array}{llllllll}\text { XIII. An Awful Oath... } & \ldots & \ldots & \ldots & \ldots & \ldots & \ldots & 118\end{array}$

XIV. Eastward Ho ! ... . .

XV. The Boer o' Bethnal Green $\quad \ldots \quad \ldots \quad$...

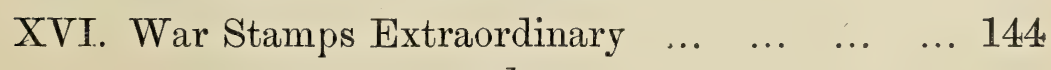




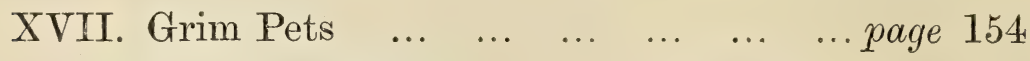

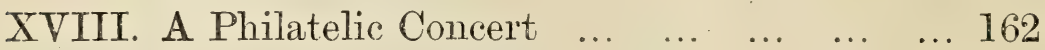

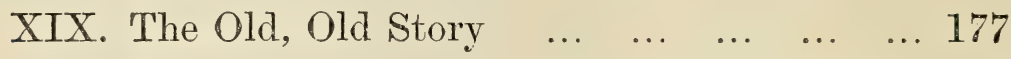



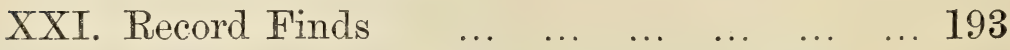

XXII. A Masterful Monopolist $\quad \ldots \quad \ldots \quad \ldots \quad$... 210


XXIV. All for The Cause! $\ldots$... $\mathrm{XXV}$. Reaping the Whirlwind $\ldots{ }^{\prime} \ldots{ }^{\prime} \ldots, \ldots 246$

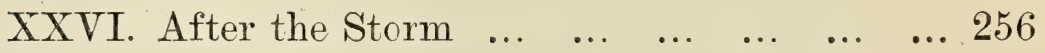
XXVII. Love's Old, Sweet Song $\quad \ldots \quad \ldots c \quad \ldots \quad \ldots 271$ 


\section{PEN-AND-INK PERPETRATIONS.}

Arms of the Wylie-Jones Combine ... ... Frontispiece. In the Grip o" the "Flu" "... .... ... To face page 5 The Man at the Front $\quad \ldots \quad \ldots \quad \ldots \quad \ldots \quad, \quad$, , 13 A Midnight Summons _.. $\quad \ldots \quad \ldots \quad \ldots \quad$, $\quad, \quad 19$ “D__ Your Pretensions, Sir, damme !" , , , 33



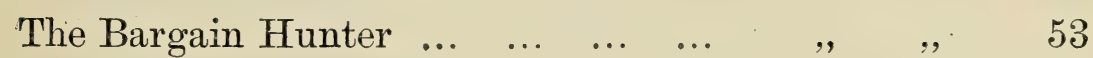

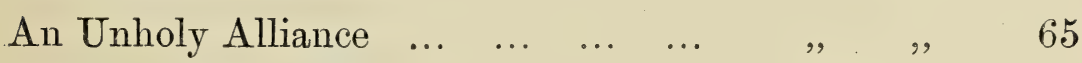

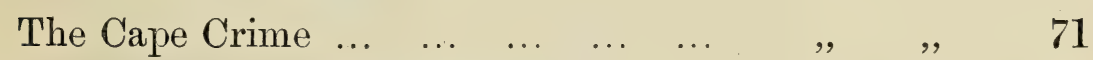
Numismatics and Ornithology $\quad \ldots \quad \ldots \quad \quad \ldots \quad, \quad, \quad, \quad 81$ Botany and Bibliomania $\quad \ldots \quad \ldots \quad \ldots \quad \quad, \quad, \quad$, $\quad 89$ Night Errand Stamp-Fiends Two .. , $\quad$, $\quad 97$ $\begin{array}{llllllll}\text { Penny Black Bess } \quad \ldots & \ldots & \ldots & \ldots & \text {, } & \text {, } & 103\end{array}$








The Boer o' Bethnal Green ... ... To face page 135

War Stamps Extraordinary $\quad \ldots \quad \ldots \quad, \quad, \quad, \quad 147$

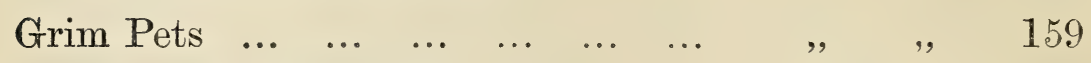

“Sweet Jam "Sandwich Girl " "... $\quad$.. $\quad$ " $\quad$ " 169

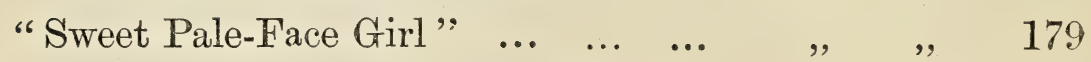

“Here's Richness!" murmured I ... , , " 187

“We Don't Get Zem in Quandidies" , , , 203

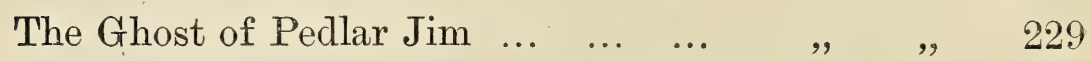

“Rimimbir Ly'dy Smiff!”... $\quad \ldots \quad \ldots \quad$... $\quad$ " $\quad$, $\quad 241$

“Queen's Messenger!” cried Paul ... , , , , 253

"We're Getting On So Nicely Now" , , , 267






\section{THE STAMP=FIENDS' RAID.}

I.

In the Grip o' the " Flu."

'Twas Spring! the Influenza-Fiend

Looked in and laid me low,

That so-called "merry month of May"

Was one of frost and snow.

"Ne'er change a clout till May is out,"

The saw, if blunt, is true,

And I had prematurely " changed"

With dire result-the "Flu"!

Of this, my third attack, will I

The memory ne'er efface,

For something most uncanny, most

Sensational took place.

The story's long - but should its length,

Dear reader, make you vexed,

I hope that you will skip this screed

And pass on to the next.

This third attack the question raised,

The while it kept me low,

"Is life worth living?"-which, of course,

Was answered long ago! 
You're this or that advised to "take,"

Which p'r'aps may lead to strife, When all you'd wish to take's your ownOr someone else's-life.

I've little faith in doctors, and,

Somehow, we ne'er agree;

To disregard of what they say

My good health's due, maybe.

But now to sink all differences

I vowed, at any price,

For what to "take" I did not know-

And so I took advice.

When said the doctor " keep your room!"

His " joke" did I resent,

" D'you think I live in one room, sir,

And haven't paid the rent?"

(My temper's quick) “ You're only fit

To practise All-fools'.day!

But don't you make a fool of me-

Not on the first of May!"

Well, in my "den " I " kept my room,"

Where hung a picture gay

Of half nude rustics, showing how

They used to keep that day.

In such Spring-garb and light, thought I,

With our Spring "weather" cursed,

They'd think a second time before

They kept this frosty " First." 
They'd have the maypole one of ice, (The North Pole found at last!)

I'd like to hear their language when

They heard the Spring wind's blast !

The " Flu" required a blazing fire, And what could I do less

Than curse (most flu-ently) this clime's

Climatic cussedness?

To grumble at the weather is

"Quite English don't you know,"

Altho' we don't get weather here, But "samples" - as they go.

Yet harping on one string, I think, One's mind (and fingers) cramps, Besides, this "poem" is-or has-

Something to do with Stamps.

A Phil am I,--please notice, that

Abbreviation's mine,

Short for Philatelist (mark you,

A Phil's no philistine!)

To coin a word or two have I

A perfect right, no doubt, For I a "poet's" licence hold, Which I've just taken out.

Stamps! there is magic in the word,

To Us how much it means, The solace of our middle age, Our old age, and our teens : 
Dead to the dull cares of the world, Yet to its joys alive,

Is he who knows how many Stamps

(Apart from beans) make five.

All non collectors welcome are

To read this story "tall,"

They're fellow creatures, and may be

Converted after all

To this, our fascinating fad,

That's free from faddist's fuss ;

We won't look down on them so long

As they look up to Us.

Outsiders need not stay outside,

Our Circle's of the best,

The square man in the round hole may

At least survive the test

Of paper, watermarks and perfs, Of gum, and "gumpaps," tou,

(A few die in the training, but

They're philistines who do!)

Then mount our gentle hobby-horse, And, novice, ride with me!

No rein need curb your " fancy" when

The steed's Philately.

'The finest " mount " you'll own, tho' you

Unused to riding be,

In time you'll say that he's O.K.

And, later on, O.G. 


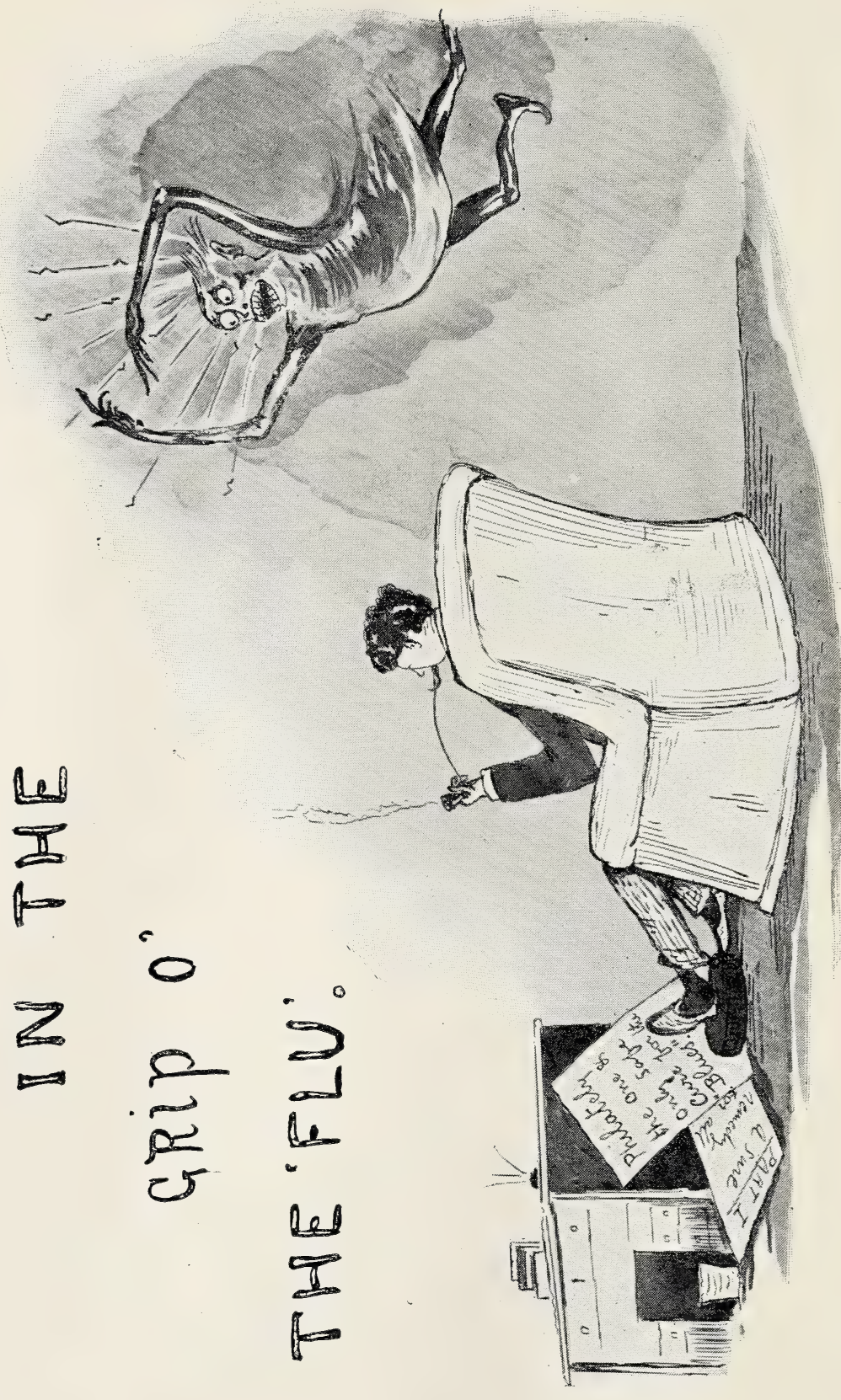


You who are old 'uns at the game,

However young in years,

Would you help one who loves The Cause-

Strive to allay the fears

Of those who, knowing naught of Stamps,

Perchance may take a look

These pages into, then-alarmed-

Let fall or close the book.

*

* * * * *

How queer indeed I felt that night,

I'd never felt so ill,

My armchair almost in the grate,

And yet I felt a chill ;

What could this strange "tired feeling" be?

(I'd never felt less fit,)

This gloomy, dark forebuding, too,

That I was " in for it."

But in for what?. I little dreamed

What trials before me lay,

What dangers dread should I pass thro'

Ere dawned another day.

My brain reels at the hopeless task

Of telling it, but I

Have vowed to write it, and in verse,

You'll later on learn why. 
I'd tried to write an article, But writing found " no go," The ink alone would run, but my Ideas refused to flow ;

Yet full of them I'd sat me down And headed thus my views" Philately; the one and only Safe cure for the 'blues.'

If I could not for others write It seemed to me that I Might emulate the few who do Their own prescriptions try. For, if Stamps failed, my case must be A hopeless case, I knew,

It might e'en mean that I was in The death-grip of the "Flu" !

Philately's a friend in need, It is indeed a friend,

For me that night it battled with The Influenza-Fiend, Whose presence I forgot, pro tem., In looking for a "want" Among some War-Stamps just received From someone " at the Front."

Here, reader, by your leave, wuuld I That "someone" introduce, So prominent a part he plays, Let that be my excuse; 
In the Grip o' the "Flu."

Pray pardon my preamble, but The subject well atones For this, my next digression, for The subject is - Paul Jones! 


\section{II.}

\section{Jiğe Man at the Prcont.}

In introducing my best chum

Forgive me if I be

Somewhat inebriated with

My own verbosity!

The subject's nearest to my heart,

And here, no doubt, I shall

The virtues somewhat overdraw

Of Paul-my special pal.

I will not gush our friendship o'er, (Gush is not friendship's staff)

Few compliments between us pass,

But lots of "cuts" and "chaff" ;

Paul has a tongue, and I, when roused,

Do not entirely lack

That member-and Paul loves me just.

Because I " hit him back."

Behind my back as "dear old boy"

He ever speaks of me,

As others do when he stands by-

For Paul stands six feet three! 
The genial giant of The Guards

Yet dubs me, to my face,

- "Ruffian" or " bounder," terms, I'm sure,

Well meant but out of place.

His head a crown would carry as

His hand a sabre fits,

And he as well could hold a " brief,"

Few "wigs" possess his wits.

An all-round man is Paul (tho" "square"),

And, could he shirk reviews,

He'd happy be in holding a

Commission in "The Blues."

He might have held I know not what,

For what could Paul not hold?

He held at least the finest "lot"

Of Capes e'er bought or sold.

His first (and dearest) hobby-horse

Was Stamps, which no rein stayed,

He curbed his second hobby-horse--

A charger-on parade.

A marvel, Paul--I marvel at

His marvellous energy,

For he, a son of Mars, finds time

To woo Philately.

This is indeed a puzzle great

That puzzles all the "cards"-

How Paul finds time to study Stamps,

For-he is in The Guards ! 
Here was the link-the strongest link

Between my chum and me,

One thing in common had we two-

The thing-Philately.

We two in common well deserve

Our Goddess's applause,

Paul risked his life (and made me, too,

Risk mine) to serve her Cause!

The Captain has - they mostly have-

Of vices p'r'aps a few,

He's an inveterate joker, and,

What's worse, a punster, too.

I've tried to cure Paul's malady,

But all in vain, altho'

Who'd think that he, who's six-feet-three,

Could ever stoop so low?

High spirits, p'r'aps, account for Paul's

Low puns and punning views,

For he (tho' in The Horse Guards) is

But rarely in " the blues."

Who'd punish him-e'en if a crime

To pass a pun it is?

For-Punitis ingeniis,

Glicit auctoritas.

As long of head as strong of arm,

Big as his head's his heart,

Fitted by nature well indeed

To play a leading part. 
Palace and cabin equally

At home in, Paul's a man

Who came out top no matter where,

As only such men can.

The ladies' pet, altho' a pet

Of most unusual size,

What snares to win the Guardsman's heart

Did many a belle devise!

Yet Paul, unconscious of their wiles,

On single life did thrive,

While traps to catch this son of Mars

Did mas in vain contrive.

Paul at the front was, leaving me

And two dear ones to mourn

His absence-may I sketch the two

His going left forlorn?

Allow me stanzas just a few,

If you have patience got,

Then I'll return to " woodblock" Capes-

Paul's rare and priceless lot.

* * * * * * * *

There prayed a widowed mother for

Her soldier lad's return,

Pauline, a doting sister, prayed-

What love some mortals earn! 
The mention of Paul's name would cause

Two pairs of eyes to shine

(I would that one pair thus lit up

Were mention made of mine!)

A stately, gentle dame is she

Whose son I've sketched for you,

Her only son-tho', an' she would,

No doubt she could have two!

Her "second boy" she's christened me

(Of course Paul's number one),

Ah! how I wish her "second boy"

Might be ber second son!

The sweet and peerless Pauline is

So like, yet unlike Paul,

For she is gentle-he is bold,

She petite-he is tall.

She is indeed the sweetest girl

Man ever gazed upon,

I hope one day-that is, I hope

To tell you more anon.

Paul oft wrote me, one of the three

To whom found time to write

The Captain, who'd been ordered South

A worthy foe to fight.

Thus would he write his folks-" We have

Of times out here the best,"

To me (on separate slips) the truth,

Marked "News to be suppressed!" 



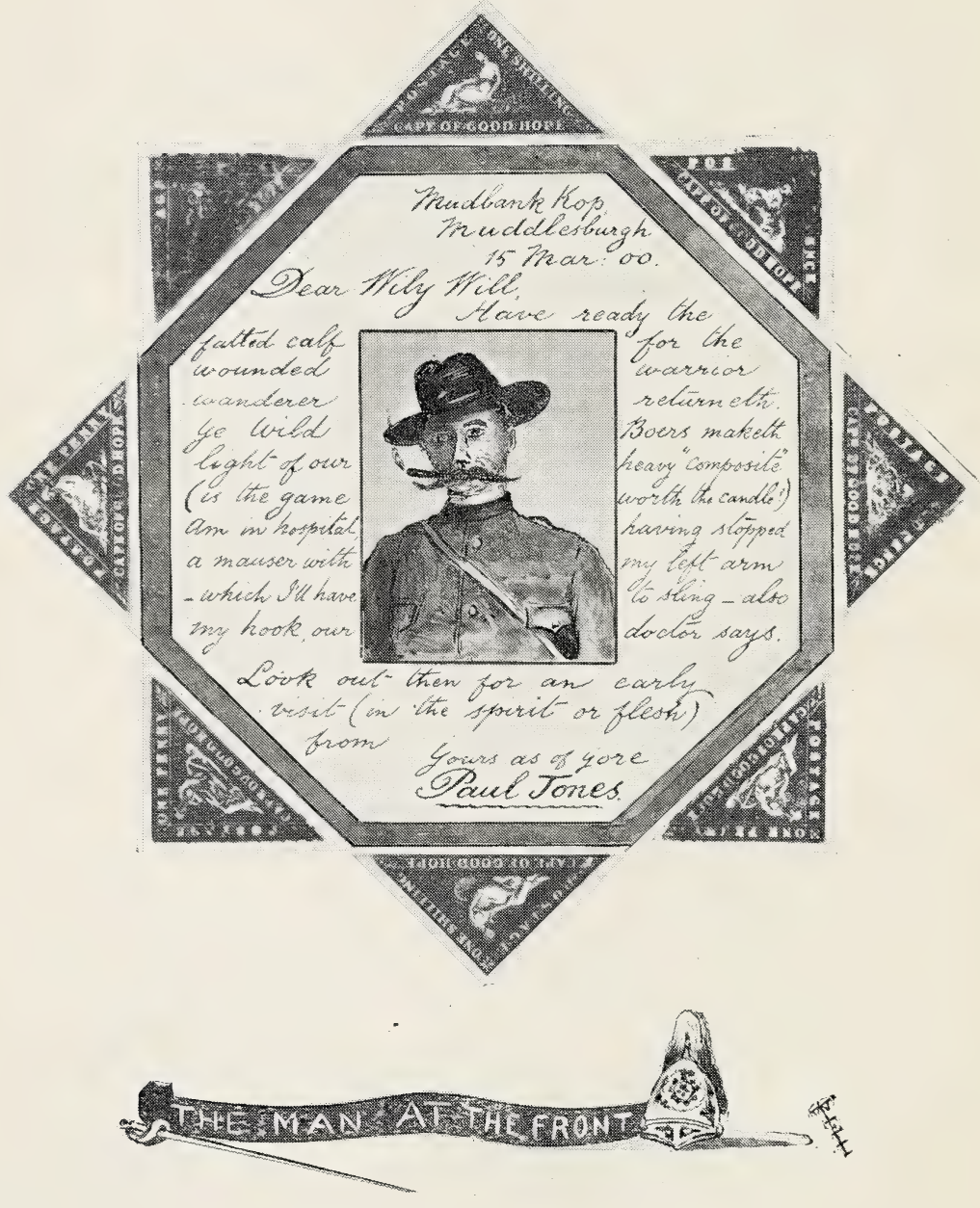


Somehow (tho' hit) Paul's name escaped The long casualty-list, He lovely "white lies" wrote his folks, In copperplate-like fist;

My task it was to " cheer them up," And courier-like sped I

From Wimbledon to Richmond-to

Endorse, alas, each lie.

To Philatelia Towers (called By some "The Richmond Gem"),

Paul's home, and where the leading Phils Oft meet-I'm one of them.

E'en in Paul's “ barrack-den" have Stamps The place of honour got, Stamps fill his "outside quarters," too, O Guardsman's happy lot!

Our Goddess also reigns supre.ue At Paul's old country seat, The quaint and rustic Woodblock House,

Cape Point, in Devon sweet.

There Philatelia reigns-and yet

Not quite supreme, I'll own,

There have I worshipped at her shrine-

But not her shrine alone.

What of myself, Will Wylie? I'm

A " rising journalist,"

The Burrow is the home, too, of

A born Philatelist. 
By Wimbledon's fair Common stands That crib, to call it such, Well known, and thanks to Paul Jones, as "The Stamp-Fiend's Rabbit-Hutch."

* $\quad * \quad * \quad * \quad * \quad *$

Now for the Capes; Jones has at least

A thousand-more or less,

A thousand Capes! (and I've but one-

A much worn Inverness),

His albums are a study, in

A study large arrayed,

You never yet saw "blanks" so filled

With Capes of every shade.

The great Cape "bloater's" "woodblock" show Those of all rivals mocks,

This "bloater's" one with many rows-

In pairs and strips and blocks.

What placed Paul on the pinnacle

Of Philatelic fame

Was one superb, choice specimen,

Whose shade could no one name.

A “woodblock" ("Fourpence") Penny Red, The "error" rare, unused,

Its margins were " enormous" (and

The term here's not abused!) 
A bonî fide "error" this,

Not one for Stamp-fiends made,

Turned many green with envy its

Strange red, an unknown shade.

Were colour charts consulted, they

Consulted were in vain,

The colour-blind then had a try,

But baffled were again;

The ladies were appealed to, and

The shade was, so they said,

"A remnant-sale crushed strawberry, or

A Swan and Edgar red."

The magazines extolled the "find,"

In most laudatory tones,

Of Captain Paul-George Stephenson-

Columbus-Newton-Jones !

Thus Paul, as a "discoverer,"

His reputation made

(And you'd have made a name could you

Have named that nameless shade).

It put Phils out of countenance, And noses out of joint,

The experts in Committee met

To sit upon the point.

"No changeling this" declared the first

Tribunal in the land,

But Paul, when asked where found his " find,"

Declined to show his hand. 
Even from me the Captain kept

The secret of the source

From whence he got the "nameless shade"

(The usual course, of course).

"I found it 'mongst an odd, mixed lot."

That was the owner's song,

Paul's since sung to a different tune-

Which you shall hear ere long.

"If not as blind as all the rest," To me, one day, he said,

“ Look here!' (he'd cut his finger and The finger freely bled)

Then Cape and finger, side by side, Jones held up to the light,

" Now you can name the nameless shade!" “By gad!" said I, "you're right!"

I'll say no more, till comes the time

When I the truth must tell,

A truth that may e'en Stamp-fiends shock,

(I do not say it will!)

Tho' fain would I lay down my pen,

Nor write this tale of sin,

By writing not, I much should lose-

By writing, much I win.

Paul from the Front was coming home,

His ship was nearly due,

And I too ill to welcome him,

Too ill to "interview" 
One who had been upon the spot,

One whom a ball had struck,

One who was also mentioned in

Despatches-just my luck!

But when we meet, thought I, we'll meet

Just in the old, sweet way,

With hearty grip, (Paul's awful grip!)

The parry, thrust and play

Of mutual "chaff" and banter broad,

With personalities

The like of which most men reserve

For special enemies !

We'll once again go "slumming," Paul,

You with your camera, I

"Sketching" the types of east end life,

As in the days gone by

When we together made our book

(Gad! how it took the west!)

“The Vagrants' Happy Hunting Ground,

Or Snap-shots in the East."

Would he be changed? A change in Paul

Could be but for the worse,

War has, p'r'aps, its redeeming side,

But what of its reverse?

I dreamed not then that such a change

Could work one year of strife,

Yet Paul,-when he returned to town,

Thought naught of human life!

$\mathrm{c}$ 
Read on, and read the story strange Of how Paul Jones returned! And learn thro' Paul's strange coming what Strange truths the Stamp-World learned, What Philatelia's Quixote and His faithful Squire went thro', What British-born Philatelists For Stamps will dare and do! 



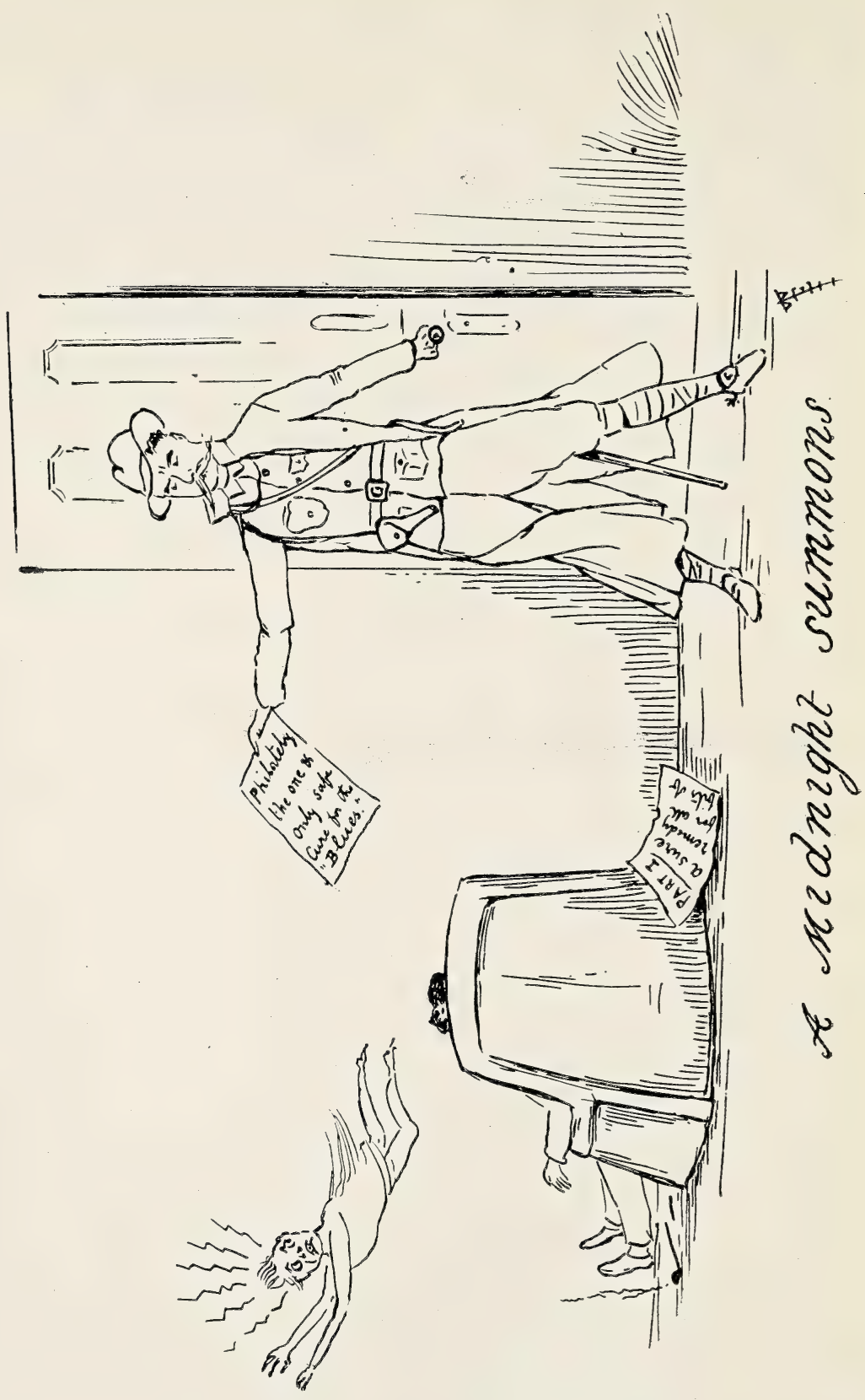




\section{III.}

\section{A Midnigh̨ł Summonş.}

"The lamp burned low and sbadows weird

Its flickering light brought forth,

Like " nameless shades" from worlds unknown

On this prosaic earth.

And as in reverie I sat-

Ere long might I have dozed-

The door was opened noiselessly,

As silently 'twas closed.

'Twas not at once that I turned round,

Yet who stood there I knew,

And when I turned 'twas but to find

My intuition true.

Before me stood, in khaki clad,

A figure gaunt and tall,

One word a deep voice uttered, "Will!"

And I aghast cried "Paul!"

No phantom this who took my hand,

No ghost hath such a grip,

I gasped "Say, Paul, what brings you here?

You're here before your ship!"

c 2 
The figure spoke, "Speak not so loud!

That I am here 'tis true,

But that's a secret only known-

And must be known-to few.

Listen! three days have I been home,

Yet I no home have seen,

My mother, Pauline-are they well?"

"Say, Paul, what do you mean?"

The cavalier in khaki but

Increased my mental fog-

"I'm back in town, lad, in advance, And I am here incog."

Paul's slouched and khaki-coloured hat Was à la C. I. V.

No pampered pet of park-parade, A brigand now looked he.

Belt and revolver, sword and spurs, And puttees were on view, When flung aside his blue, great cloak The great Cape "Oxford Blue."

"Sit down, old boy!" but still he stood, Not did he stand "at ease," But stiffly, and I wondered why

My welcome failed to please.

"My cab, with Black Bess, waits below, And I soon off must be, And you, yes, don't look startled, man, To-night must come with me! 
Now listen, Wylie, I to-night

A summons bring for you."

"A summons, Paul-for what amount?

And say to whom 'tis due!"

"You owe to one a heavy debt, I owe as much 'tis true."

"Then, dear old boy, lump mine with yours And take my I. O. U.!"

"I summon you, and should you fail To answer to my call,

A judgment follows, swift and sure!" "A judgment-summons, Paul?

With gas and water summonses But little doth remain, Just glance around my den and say On what will you distrain!"

"You're summoned by the sacred tie(He eyed my tie's bright red)

The sacred tie of friendship ("What An awful tie!" he said).

If any power o'er you I wield (I owned he wielded some)

With me to-night I summon youI summon you to come!"

"You really speak in riddles, Paul, Your plan I understand's

To-night to carry off this wreek, Who's in the doctor's hands." 
“Then I'll release you from his grip,

Your doctor won't repine,

They often lose their patients and-"

Said I, "I'm losing mine."

"Come out, you wretched scribbler, come!

Don't feign to earn your bread,

(Your hobby's harmless I admit-

Because your stuff's not read)

With change of work (like " changing guard ?")

You'd learn what work meant, Will,

I wonder you don't chuck the pen-

I mean resign the quill."

"Poor Paul," said I, " your lot is hard,

You have no chance to shirk,

I've heard how soon they kill them in

The Guards with over work ;

The bondage of the slaves' Brigade

'Tis time you severed from,

I wonder you don't chuck your stars-

I mean-resign your Com."

"No time to jest nor play the fool

Is this late, solemn hour,

Hark! hear you not the midnight chimes:

From yonder belfry-tower?

For you a stroke of fortune means

Each solemn stroke you hear,

The bells heard by Dick Whittington

No promise held so fair." 
Paul spoke as might Macready speak,

(Whom I've not heard nor seen)

With glance as keen as might have been

The eagle glance of Kean.

The crucial point was reached and I

Must Paul's strong will oppose,

I rose to the occasion then, And from my chair I rose.

"If I come out to-night," said I,

"To certain death I go,

I've not p'r'aps long to live." Said Paul, "If you don't come-that's so!"

Thought I, between my doctor and My maybe mad friend Jones

None but a fool would prophesy That I shall make old bones.

"Not for an idle purpose I Would take you out to-night."

"You'll take me out for nothing, lad, So that so far's all right."

Paul sat him down with folded arms, His smile was calm yet bold,

A smile that said, if smiles could speak, " The trump card yet I hold."

"In friendship's name (what's in the name If at its call you fail? )

The name of her whom you may love, (Should that alone avail!) 
But failing that, I summon you-

And summon you, what's more,

The honourable name in of

Your honourable corps."

(A crack and ancient corps élite

Each represented here,

The pampered Household Captain and

The long-snubbed volunteer ;

One Captain in the Cavalry-

The famous R.H.G.,

The otber in the infantry

Of London's H.A.C.)

"But mark-no social function this !

No City Road parade,

(A " smoker" we may have 'tis true-

But of a different grade)

Thro' you to-night the H.A.C.

Of glory wins its dues,

A heavier weight's my shoulders on-

I represent 'The Blues.'

What! hesitating still to serve

The one and only who

In her dire strait can only count

Upon us soldiers two?

One you would give your life to serve,

You know the one I mean,

Just think of her for whom you'd die!"

I thought of sweet Pauline. 
I hate conundrums, so I let

My thought a thought remain,

And made no guess-I know the game

Of guess and guess again.

"One whom you're pledged--nay wedded to,"

Yet still I feared a snare,

The while I thought of someone and

I thought-I wish I were!

"You've vowed, and oft, that as you've used

The pen you'd use the sword,

If needs were, in a certain Cause-

I take you at your word:

Write with the sword - the pen of fame--

Your name upon the page

Of Fame's fair book, and in that Cause

To-night take up the gage!

Arise and follow-here no more

In fancied sickness stay!

For, Will, remember where there is

A will there is a way.

We'll take a turn at fortune's wheel,

Knights errant we, what ho!"

Said I "It sounds absurd on this

Night's errand forth to go."

"Hast thou a soul to call thine own?"

This taunt at me was cast, And I, for rhyme's sake if alone,

Proudly replied "I hast !" 
"A guilty secret I'd impart, Say, wilt thou share the guilt?"

I'd caught Paul's mediæval tone And boldly said "I wilt!"

“This midnight summons is for you To be my trusty squire,

I know your grit-would you for me Thro' water go and fire:

Yet even more you'd dare for her, At naught you'd quail or pause, To-night I summon you to fight In Philatelia's Cause!",

I rose, we two as one man rose, Two hands met in a grip, To seal a solemn compact as Could seal no word of lip.

"A call from such high quarter can On no deaf ear e'er fall, On one condition count on meSit down and tell me all!

Keep me no longer in the dark, I'll see truth's light," said I,

" Bring forward all you're keeping back And then I'll do or die; If from Our Goddess comes indeed The call, I will not pause, But cast my lot, lad, in with yoursIn Philatelia's Cause!" 
"Time presses, but your claim is just," Said Paul, " and I'll comply,

I hear Black Bess's whinny, but

Her patience I must try-

And yours, my friend, the story's long,

Blood curdling, thrilling, sad."

Into an armchair facing mine

Paul dropped, and bared his head.

"Why to myself should I e'er keep

The source of my great finds?

"Is such a practice worthy of

Broad philatelic minds?

Should each tell each, and truly, where

His treasure-source lies hid."

I answered, to encourage Paul,

"I thought they always did."

There's something great to follow this

Prefatory harangue

Methought, and then-O ! happy thought !

To loosen Jones's tongue-

To say "No" to my "Special Scotch"

There are indeed few men :

Without delay I brought it out

And said to Paul, "Say when!"

For here were precious Stamps concerned

And I was far from blind,

I saw by something in Paul's face

He'd something on his mind; 
I mixed it (Paul's share) half and half, On this might much depend,

For naught could raise a "Scotch mist" as

Could my true " Highland blend."

Paul as a smoker tackles what

Lays many a smoker low,

My Indian Cheroots came out,

Six inches long or so,

Reserved for such as he; thought I,

To-night it's " $d$ - expense."

And then we settled down and he

Commenced to "talk immense."

* * * * * * * *

"A Areat Stamp-secret now would I

With some bold spirit share,

And where's a bolder than yourself?"

I simply echoed "where?"

"A secret long and closely kept

Will I to-night divulge-

The place where I have found my finds!"

My eyes commenced to bulge.

"A place so near and yet so far, So rich and yet so poor,

A philatelic Klondike, lad, Rich in the rare Stamp ore: 
But to the crowd its whereabouts Shall ne'er be told by me, For I am, as you know, a true Philatelist," said he.

"Shall I go on ?-for mark you this, If you decide upon

A visit there, 'twill try your nerve!" "Go on," said I, " go on !"

"A crime's connected with the spot, Who'd write it up would need, To stamp the deed for what it is, A blood-red ink indeed!

A pedlar there was murdered, andWas murdered-" Paul stuck fast, (The present speaker is, methought, A speaker with a past).

"Was murdered," he continued, " and Before he could escape, Was murdered, foully murdered for A penny Woodblock-Cape!

The memory of that fearful crime Effaced by time is not, And once a year the pedlar's ghost

Perambulates the spot;

To-morrow is his ' annual,' The ghost I've never seenAnd never wish to-_" "Well," said I, "I can't say that I'm keen." 
"To-night we'll miss that show, for it's The night before, you see, The awful crime committed was-"

Paul's crude chronology!

He doesn't care a fig for dates, If this point up he'd cleared, What horrors he and I-and you, Dear reader, had been spared!

“Listen! and I'll two stories tell, They'll give you reasons some Why you I ask with me to-night To come-and why you come. They're bare facts minus ' dressing' and The naked truth denote, One tale concerns a blood-red Cape, And one-a gray fur-coat.

The yarn, or yarns I have to spin May make your head spin round, In fact you'll find yourself quite lost Ere you the point have found;

It is indeed a tangled skein, Tho' truth's the centre shred, But you will 'cotton' to the yarn As I pick up the thread." 


\section{IV.}

\section{IIhe Grqạ Fury-Coat.}

My Uncle, " Old General Joe,"

A bachelor was, as you know,

He'd seen lots of service, but when marriage service

Was mentioned he'd sing " Not for Joe!"

He met late in life his first and last wife,

Tho' single he lived and he died,

All women he'd swear were naught but a snare--

So he made Philatelia his bride.

Ere Uncle retired on half pay

He had, in his way, had his day,

He'd seen lots of strife and taken much life

Ere he took up with Stamps-on half-pay.

Find Philately quite a source of delight

Did “ Old Joe," who'd once found killing prime,

Of life few would tire who on h.-p. retire

If with Stamps would they start killing time.

Some folks thought my uncle was daft,

At his harmless, pet hobby, they "laf't,"

Fools may say, if they choose, that he'd " got a tile loose "

And his "thinking box" let in a draught. 
He was far from insane tho' he'd " Stamps on the brain,"

(A gibe of the non philatelic)

Such little digs, tho', they kept from " Old Joe,"

For his temper was rather choleric.

P'r'aps this was the bee in his bonnet-

(His memory will live in this sonnet!)

He set up a claim, and, to strengthen the same,

Took his oath-many oaths took upon it;

That claim he'd ne'er share, tho' many might swear

Their claims were as well worth dissecting,

Between you and me, "Old Joe " claimed to be

The first man who started collecting!

Who first wooed the fair Philatelia

Is a delicate question, and really a

Question that's pert, for she wasn't a flirt,

'Tho' a first love had fair Philatelia.

But this I maintain - and so would Val Vane,

(You'll hear more of uncle Joe's valet)

As likely as not unc' was first on the spot

As regards what Vane called "fillytally."

The Joneses don't do things by halves-

By the horns they the bulls take (not calves)

(Tho' that took me some time, if it ain't " half a rhyme"

Well the Joneses don't do things by halves).

To jump uncle's claim did scores make the same,

Quite forgetting there's only one Jones,

They put a good face on a very bad case,

But mere "face" for mere cheek ne'er atones. 



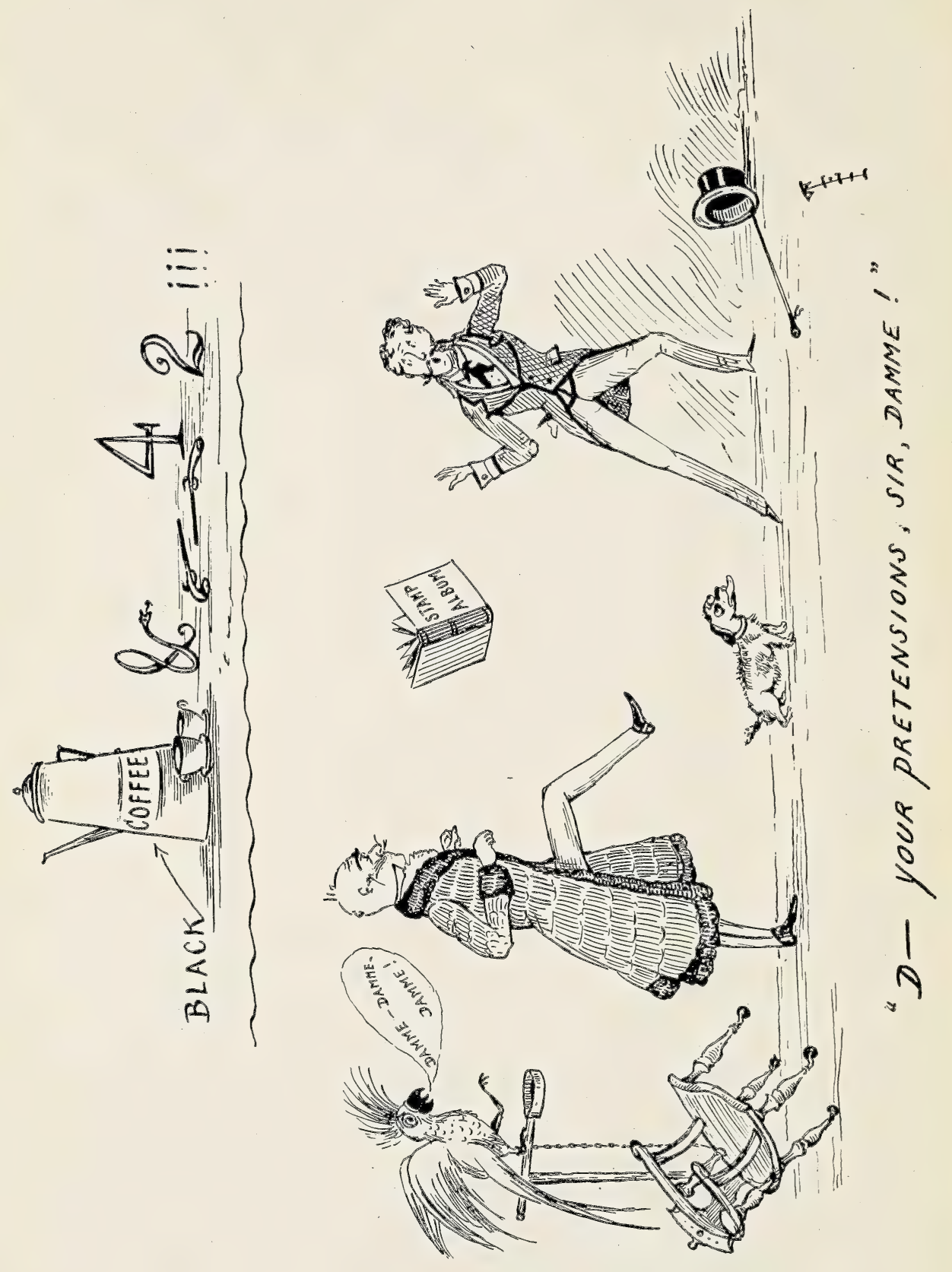


Re discussions on " the first collection"

Uncle oft sent the mags. a correction, [ [know," Which he'd sign "Fighting Joe," or else "One in the

So his readers could trace the connection.

He once fought a duel-made his man " take his gruel"

Who called Joe's " an impudent claim."

The challenged, I fear, walks minus an ear,

While uncle, who challenged, walked lame.

His Stamp-reputation 'tis true

To him was what yours is to you,

(Tho' honestly made!) so he called in the aid

Of coffee and "pistols for two."

His unerring hit and quick mother wit

Most rivals would take unawares,

If the glare of his eye failed to silence reply

He'd trot out a few army-swears.

To inform him once ventured some fool,

Of the I-was-the-very-first school,

"I started my book with the old Penny Black

On its first day of issue." (the fool!)

Uncle glared at the fool, then he roared like a bull

"Why I started my 'lot,' you soft sammy,

With a Penny-Black proof, so hang, sir, your 'spoof'

And damn your pretensions, sir, damme!"

Had uncle (not he of the "spout")

Good points and redeeming, no doubt,

Was his word pledged to me that his Stamps mine should

When he (as he put it) " pegged out." 
He made me a Phil and said he " Lad, I will

Leave you something at least worth a groat, Tho' not down in my will 'tis a rare item, Paul, As you love Stamps, preserve my fur-coat!"

"Old Joe" wore a coat of gray fur, To wear which he'd never demur;

In Spring or in Autumn, when few folks will sport 'em, You'd oft meet my uncle in fur.

Thro' winter and summer (what's known here as summer!)

Without it he rarely would stir,

That he'd got, however, a chill on the liver,

You might, from the fur-coat, infer.

Tho' he did not collect in a book,

Of his Stamp-treasures great care he took, For a pocket inside of the fur-coat he'd made

Which to find would trick Maskelyne and Cook.

He showed but to me this pocket, said he

"The Stamps you'll find there when I'm gone

Will upward go flying (I know what I'm buying)

In value-as sure as you're born!"

I'll give the old brick, Will, his due,

He left me his mansion (there's few

But swear by The Towers-Philatelia Towers,

Or rave o'er "The Richmond Gem View")

And all of his money (he called me his "sonny"),

His yacht The Mulready (and crew), ["shot," But the Coat, which I've not, was, p'raps, worth all the The yacht, and "The Richmond Gem View." 
"Joe" never consulted a cat, At the time he bought stamps-what of that?

A "mint" of each issue he put by in "tissue," Face value, he reckoned, was cat!

In that pocket "blind," which few eyes could find, Choice first water "gems" did he stow, Was that fur material a walking " Imperial," I knew-but Val Vane didn’t know.

Val Vane was for year's Uncle's valet, Mr. Valentine Vane, known as "Vally," I'll ne'er meet again a " man " quite so vain As vain was Val Vane, the vile valet; I'll let "vile" remain, and why-I'll explain, My thoughts I must now try to rally, But the greatest ill one could do to a Phil

I received at the hands of that valet.

Had I then but seen thro' the valet, Of death he'd have passed thro' the valley.

Should we meet, sure as sin, if I get my right inI'll just knock a hole through the valet!

F.r. each thing, you know, of my poor uncle Joe That villainous valet went, thro',

I shan't dilly dally if I meet that valetThere's not room on earth for us two!

My uncle " pegged out" at short notice, Without even giving me notice, (The rule, I believe, when one's going to "leave," Is to give, say at least, a week's notice).

D 2 
Ere uncle was dead Val piled on the bed

His clothes-for he'd acted as nurse,

By law he could claim, they tell me, the same,

And the fur-coat he claimed-as a nurse!

So wily that valet that he

Would have "done" e'en the heathen Chinee,

A man half so wily (excepting Will Wylie!)

I never, Will Wylie, did see.

Next day off he hopped (and something he "popped")

To a shop with the Lombardy sign,

That villainous valet took round to his " uncle"

The coat that he'd stolen from mine!

Like the fur-coat, Val never came back, Tho' of course I was soon on his track,

I called Val a pig and I called him a prig-

But that valet I never called back.

This slyest of sharks packed off with his "perqs,"

And, tho' London I travelled half thro',

I never yet ran up against uncle's " man,"

There'll be ructions, you bet, if I do!

To recover that coat no exertions

I spared, but made many excursions,

I put tecs on the job, and spent many a "bob"

In ads. (for a bob three insertions).

The "uncle" with whom Val " popped" the heirloom

Said the pledge was redeemed by a Jew

Who brought in the "ticket"- -but 'twasn't the valetAnd that's about all that he knew. 
Don't think that I've told you a story, At yarning I'm not in my glory,

I've told you, forsooth, the truth, that's the truth,

I've not, mind you, told you a story!

I've since found a clue and now ask aid of you,

The coat I've discovered all right-

And by whom, too, and where 'twill be worn, and I swear

To recover the fur-coat to-night!

* $\quad * \quad$ * $\quad * \quad * \quad * \quad * \quad *$

The second tale now, and accursed,

I'll tell you, by far it's the worst,

I've some recollection there's some close connection

Between story two and the first.

You don't like my metre? Well, I'll try a neater.

Said I, "Wait a minute or two!

Your jingle absurd of some rhymes I once heard

Reminds me-and I'll quote a few :

\section{Random Rhymes.}

There was a young man from Calcutta

Who'd contracted a permanent stutter,

'Twas, sad to relate, caused by some Native State

Whose name he attempted to utter.

There was a young man from Peru

With 'overprints' novel and new,

Said he, "I can swear these " triangless " are "square,"

For everything's "square" in Peru.' 
There was a young novice ambitious

To buy a Post-Office-Mauritius,

He went, pence in hand, to St. Martin's Le Grand,

But they'd sold out the P.O. Mauritius.

There was a sly 'faker' from Jhind,

Who'd faked a Faridkot and Scinde,

Of the first he'd 'no doubt,' but, when that was found out,

He didn't let out that he'd Scinde!

Uncle Sam, who stood biting his nails, Said 'Darn' Periodical 'sales,

Since I floated that lot a slating I've got

By darned periodical mails!'

Now a cute Yank who'd sold e'en his shirts

To buy up the 'Buffalo' inverts,

Cried 'Christo' Colum'!' (tho' the shock struck him dumb)

- They turn 'em out slicker than shirts!'

There was a young man from Bengal,

Who said that he'd got a Nepaul,

But it turned out to be a label for tea,

So he found that he'd got none at all.

Said a ' green' novice 'I've found a Nevis, As an " error" the stamp, I believe, is

The rarest of bits-for it's surcharged " Saint Kitts" , -

Said the evergreen novice in Nevis. 


\section{Personal to Paul.}

There was a young man from the Cape,

Who told half his tale of a scrape,

Of a fur-coat he spoke-then threw off the cloak

And took up the tale of the Cape."

Said Paul, "I'll take the hint, my friend,

And take another 'weed,'

I'll also take another ' Scotch' -

Strong nerves will this yarn need;

It's time I told what's on my mind,

'Twill ease my mind to tell

The awful secret kept so long."

"It will," said I, "it will!" 


\section{V. \\ The Blood-Red Cape.}

It happened, what I'm now about to tell, Some years ago, I can't remember well The day and hour, the month, nor even year, For time and dates my memory's rather queer, (And yet I would that I remembered less!)

It happened in-as near as I can guessThe latter half-the month I cannot fixOf early Spring, in Eighteen-something-six.

One morning, in our well beloved Strand, Before a stamp shop-window did I stand, Regarding with a cold eyed stare and rude "Seebecks" and such like, pretty, cheap, and crude. When someone touched me and I stared at him, A Jew street-hawker, hawk-eyed, pale and slim, Suspended from his shoulders was a tray On which his cheap and nasty knick-knacks lay.

Shirt-studs and links, and such like wares that come From that cheap wonder-city known as Brum, Watches and watch-chains, scarf-pins, hairpins, dire, Mostly a penny - cheap, too, at the price; 
Why cannot Stamps, methought, be made as cheap?

Such as I buy of pounds cost me a heap;

I to the dealers had that very day

Sent cheques that sent a thousand pounds away.

He of the long lost tribes (found in the Strand)

Something to show had and he "showed his hand,"

I who can read hands, aye, and faces read,

Read that the man before me stood in need

Of something I had which he had not got,

My gift is occult (did you mutter " rot"?)

For ere he spoke I took his measure true-

A Cockney, cosmopolitan, Christian-Jew.

"You buy some stamps-some rare stamps cheap to-day?"

Ah! yes, you buy, I see-you come this way!"

He led-nay pushed me up a dark by-court,

Weakly I yielded, why-I've never thought;

This sort of thing had happened oft before,

It's scandalous, tho', that rogues who don't, I'm sure,

Pay rates or income-tax should thus waylay

Clients of those who do such trifles pay.

It's unfair to encourage such a trade,

How should I like it if some hawker made His " pitch" to catch my clients " on the hop"

Outside my Stamp-shop, if I kept a shop?

The principle is bad; besides, you take

Risks, and may buy, as I once did, a " fake."

Now for such rogues I've ne'er a sou to spare-

Unless for something genuine, cheap, and rare. 
This time had my integrity been proof

'Gainst what I deemed to be a pedlar's "spoof,"

But I inveigled was, aye, even shoved

Up the blind alley, or, maybe, was moved

By his request alone, for I could see

'Twas prompted, there's no doubt, by poverty.

I felt relieved to think 'twere no disgrace

Of Stamps "relieving" a deserving case.

Was it not luck for me that he produced "Gems" of my own pet country, all unused?

Beneath my breath I thanked my lucky stars, Capes, by the holy joss-triangulars!

But I displayed a diplomatic mind, And cheapened thus my Oxford-Turner " find."

" How dare you offer such-at any price?

I've half-I've half a mind to call the police!"

The ruse well answered, for did I observe That, unlike me, the rogue had little "nerve," "For selling Stamps have you a licence got? Mind, these Stamps are unused Stamps, all the lot!

I should, by rights, but don't wish to be hard, Take these, and you as well, to Scotland-yard. No licence?-why without a licence, worm, Is penal servitude for life the term!"

He quailed at that, it sounds to you sad stuff, But he believed it-that was quite enough. Had not the knave seduced me from the Strand, That he some "fancy prices" might demand? 
"Ten bob" he let drop, thus compelling me To let drop something with a great big D ! "Ten bob, you knave?-there's only ten Stamps here, 0 ! you like penal servitude, that's clear!"

'Tis the unwritten law of all our cult Never indeed to let yourself be mulct For more than half the price that vendors such May ask you-for they always ask too much. Tho' an unwritten law (said I “ And one Not worth the paper that it's written on ") To break such law should I be e'er accursedI'd sooner break the Ten Commandments first!

Of this broad principle I hope I take No narrow view, but, for my credit's sake, I'd like you here to fully understand How I abhor the forcing of my hand. Had fifty pounds that pedlar asked, I say Pounds twenty-five I'd been prepared to pay, " Five bob," on principle, I offered then (The regulation half) - he still asked ten.

The vile intention of the cunning cad To drive a bargain nearly drove me mad. (The "five bob" difference was a bagatelle, But I of bargains love my friends to tell), Then from my pocket I five shillings drew, At them a hungry glance the ruffian threw, I charmed the pedlar with their magic clink, "Take 'em, my man, and--I'll stand you a drink!" 
That settled it, five shillings bought the "lot,"

Of Gibbons No. 17 I got,

With margins wide, a mint unsevered pair

(Fool to stand treat-one had a tiny tear!), And No. 28 was worth the sum-

Altho' the shilling green had not full gum. (To " missing perfs" I no attention drew, For “Jim " might know too much-altho' a Jew.)

Why did I drive so hard a bargain? Well, Of such a "drive" would you your friends not tell With pride considerable? Most Phils would brag Had they the luck to make so big a bag.

Envy it roused, that great sweet'ner of fame, Phils coupled mine with Vernon Roberts' name, Some spoke their doubts, tho' doubts can break no bones, One sceptic dubbed me "Brattleboro" Jones!

My knowledge of the law and Scotland-Yard, And penal servitude, won Jim's regard And deep respect; for my hypnotic force, Used for his good, did him much good, of course.

Under my eye, no doubt, had he kept straight, He tried no more his prices to "inflate," But took the market-price, as fixed by me, And gave no trouble-whilst he had drinks free.

Then oft by accident I dropped 'cross Jim, $I$ in the Strand was always meeting him, That "Pedlar Jim's" was a deserving case I'd now no doubt, and paid him value face 
For all the Capes he sold me, new or old. "The older, Jim, the better," he was told,

"I like the old ones" (which of course was true),

"' 'Tho' not worth half so much, Jim, as the new."

"The Cape Boy" was the title I conferred

On Jim (whose treatment-it has just occurred

To me-was better far than that of some

"Cape Boys" who down the Strand may never come).

When he struck 'gainst my prices, once or twice,

I'd fix him with my eye, then fix my price,

But generally the price he asked was such

That I'd no heart to cut it down-too much.

The human eye, you know, a power has great,

I know it, for I've used it much of late;

It can "suggest" and thus the Cause assist, And vou can " best" the best philatelist

When "swapping," or see that an auction "lot"

Is knocked down to you-if the eye you've got.

Here for hypnotic science is a use,

What I myself condemn is its abuse!

Then came that fatal day for Jim and meI took the "C.B." to the A.B.C.

For once, thought I, I'll wean Jim from the pub, And tea shall triumph over rum and shrub.

I do not wish to magnify the job,

But, still, that pedlar's tea cost me a bob,

It's simply great how those street-hawkers feed,

But mark the active, airy life they lead! 
Under an obligation this " high" tea"

Would place, methought, the low-born one to me, And Pedlar Jim a generous host had met, For, after tea, we had a cigarette.

Now from the grateful "Cape boy" it would seem I'd learn the strange source of the great Cape stream, To buy the secret naught was spared by meI ordered Jim a second cup of tea.

Ordered "well drawn "-as Jim I meant to " draw," And into it I dropped a spirit raw, "Cape smoke" would make the "Cape boy" bare to me His mind-if called a mind could Jimmy's be! Strange truths I learned, all long since verified, The source of those rare Capes to learn I tried, And learned it-keep your seat, for you also Shall learn it! Two words name the source- "Ole' Clo'."

Ole' Clo', old papers, furniture, and books, The first-named takes in all-as do the "rooks" That buy such things up from the thriftless throng, Who know the things not that to them belong! Jim was a member of a clique or gang (Of which, no doubt, each member ought to hang) Who dealt, like Jim, in all things now and then, And owned as chief a Jew-"Big Birdcage Ben."

One who lent money (at the usual rates Of interest) to impecunious " mates,"

Played the rack renter and the sweater mean Round Houndsditch, Spitalfields, and Bethnal Green; 
A fighting Hebrew and an ex-dragoon

(Was I to meet him and to meet him soon)

A factor prime in the vile scheme that draws

The alien pauper to the sweater's maws.

* $\quad * \quad$ * $\quad * \quad * \quad * \quad * \quad *$

E'en Stamps must stand aside the while I state East London's wrongs, which I would ventilate ; On Alien Immigration soon may sit

A Royal Commission-what will come of it? Like such Commissions, 'twill but sit and rise, And rise and sit, and then-advise, advise. But I've a scheme to win the "gods" "applause, And right their wrongs-In Philatelia's Cause!

I learned enough from Jim to understand How fare the natives of our native land; Himself an alien, yet did he reveal Such facts as should the fate of aliens seal; An average of twenty-seven souls In each room pack the vile, rack-renting ghouls Of those congested districts. Who'd compare Starvation's deaths with deaths from want of air?

This overcrowding's mostly felt and seen In the once purely British Bethnal Green, That stronghold of the Cockney Simon Pure Hath lost its glories of the days of yore. 
Russian, Hungarian, Pole and Portugee

Have ousted there the aboriginee,

"Arry and 'Arriet, Bill and 'Liza-few

Remain of such true types where reigns the Jew.

But Cockney pluck a stalwart few inspires

To hold on in the birthplace of their sires,

Are midnight raids and desperate sorties seen

From the wild fastnesses of Bethnal Green;

A fearless forty odd, and yet a power,

Well led (for comes the man when comes the hour)

By one whose scouting skill in this slum-war

Has earned for him the title of "The Boer."

For "Fair rent" now the "Fighting Forty" call (The Irish section cry "No rint at all!")

" But this is not Philately!" "Maybe

Between the lines you'd read Philately

If you read signs and men as I can read,

Close the connection you will find indeed

'Tween Stamps and those whom I will cause to-night

To rise and in The Stamp Queen's Cause to fight!

Stamps in good time, but you must hear me out, For our fate linked with that is of the "scout,"

To-night a raid we make-our risk is small,

For raids to-day don't count as raids at all.

We two, at least, may hope to 'scape scot-free, 'Tho' some must suffer-for Philately.

Death or the Fur-Coat doth our mission mean, And with us is "The Boer o' Bethnal Green!"

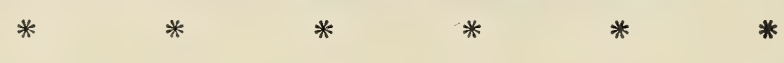




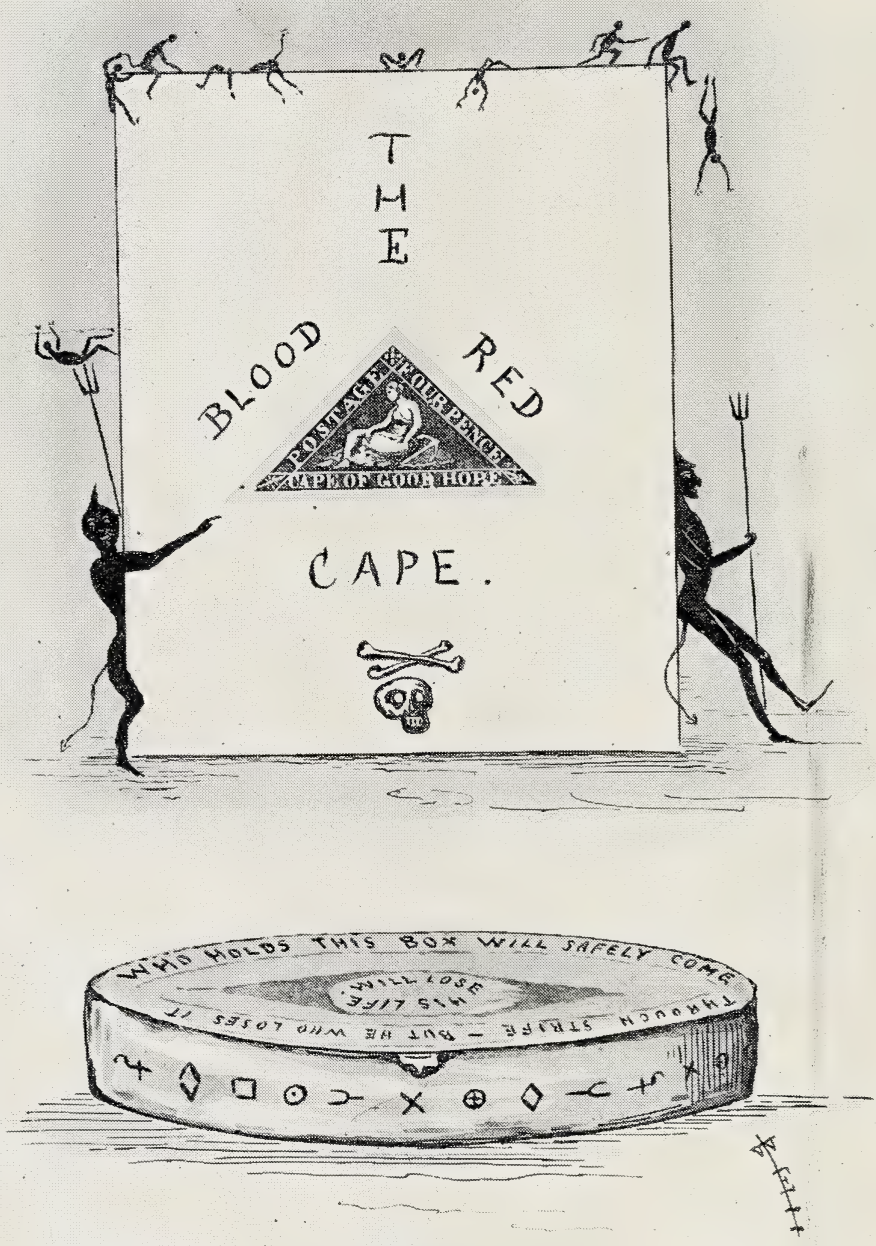
And then Jim showed me-see, I hold it here-

A snuff-box, are the ways of fate not queer?

This was his charm, which some old tallyman,

So Jim said, gave him as a talisman.

Quaint, is it not? - of this I'll ne'er get rid,

For read the strange inscription on the lid:

'Who holds this box will safely come thro' strife,

But he who loses it will lose his life.'

Note the strange signs engraved the box upon!

Thieves' signs, I'm told-no doubt by Jim put on.

I did not know then, and I questioned him-

"Are you a mason?" Said the pedlar slim,

"No, I'm a glazier sometimes"-which explains

Why poor Jim's life had been so full of pains,

Alas! Jim will put in no pane again,

For he himself has been put out of pain!

"I don't take snuff, Jim, I can't bear the stuff," ('Tho', in a worldly sense, I'm ' up to snuff')

But in the box was naught at which to "sneeze,"

Nor turn one's nose up at-what, if you please,

Think you I found there? Ah! you'd never guess,

Only a Stamp and nothing more nor less.

But such a Stamp! Of all the Capes e'r seen

Good hopes had I that I'd found Good Hope's Queen!

You've seen the Stamp, you and the chosen few, Think what I felt when I first came to view

That Stamp unique and specimen superb!

Noun, article, and adjective, and verb, 
However strung together, can't convey One-tenth part of my joy and dismay ; For language fails to paint, when all is said, That Cape of the forbidden shade of red.

Forbidden to the crowd is such a red. I'd often read, and often heard it said That, of this red, one specimen alone Was known-but whose it was was never known. Here was the Stamp itself, my cheeks turned white, And lacked the special shade of that Stamp quite, Think me not weak that I myself betrayed, For this Cape was the priceless Bload-Red Shade! 


\section{VI.}

\section{A Bargain-Munfer.}

Alas! my cheek (not " cheek") now spoilt my hand, At once the "Cape boy" seemed to understand. "'That's worth two bob, great Moses, any day! Too much? - all right, then I'll stow 'im away, So 'elp me on that stamp could you go nap!"

Closed he the snuff-box with defiant snap, "Here take your bob," said I, " and end the job!" But doggedly he answered "No, two bob!"

Then at the "slim ". one epithets I hurled, Such as he'd never heard in his low world, "You shameless shirker of all honest graft! Bottomless pit of Machiavellian craft!

You sly, sophisticated Shylock's son!

You imp of Satan, offspring of a gun!

Epitome of Philatelic crime!

You chronic oakum-picking doer of time!

Appendix to the Newgate Calendar!

You're one and all of these, not one I bar!'”

I stopped for lack of breath, not lack of word,

The pedlar shuddered as the "names" he heard,

E 2 
In his look was a combination seen

Of doubt and fear and admiration keen,

“Why, guv'nor," muttered he, with puzzled air,

“There's none round Spitalfiel's like you can swear!

Big Ben ain't in it ; tho' as big as you,

He can't swear like that-_s'elp me bob it's true!

Ben likes your kidney, straight, if you come there

You'll pal on, 'cos you'd make a nobby pair.

They calls him 'Birdcage' 'cos a downy bird

At plucking ' pigeons' - but, you take my word,

'E can't pluck you, 'cos you're on the same lay,

You two would leave no feathers on a 'jay'!

Ben's heard about you and he's mighty keen To meet you, too, it's business what I mean'Cos 'e gets tons o' stamps, but dunno where To sell 'em-I'm the only 'ole clo' ' there

As understands 'em; let me take you down, Ben wants a toff, as knows the West o' town, To work the biz, and, if like biz you feels, T'll introduce you down at Spitalfiel's."

Said I "I'll have to introduce my toe If you don't sell that Stamp!" Cried Jim "Wot O!" (He didn't add " she bumps," or I'd have slain Jim on the spot!) I knew I'd made again An error -and an "error" too had lost. To think, too, what the "Cape boy's" tea had cost! He rose, and daring now at me to scoff, Cried "Chase me, Charlie!" and the rogue was off. 



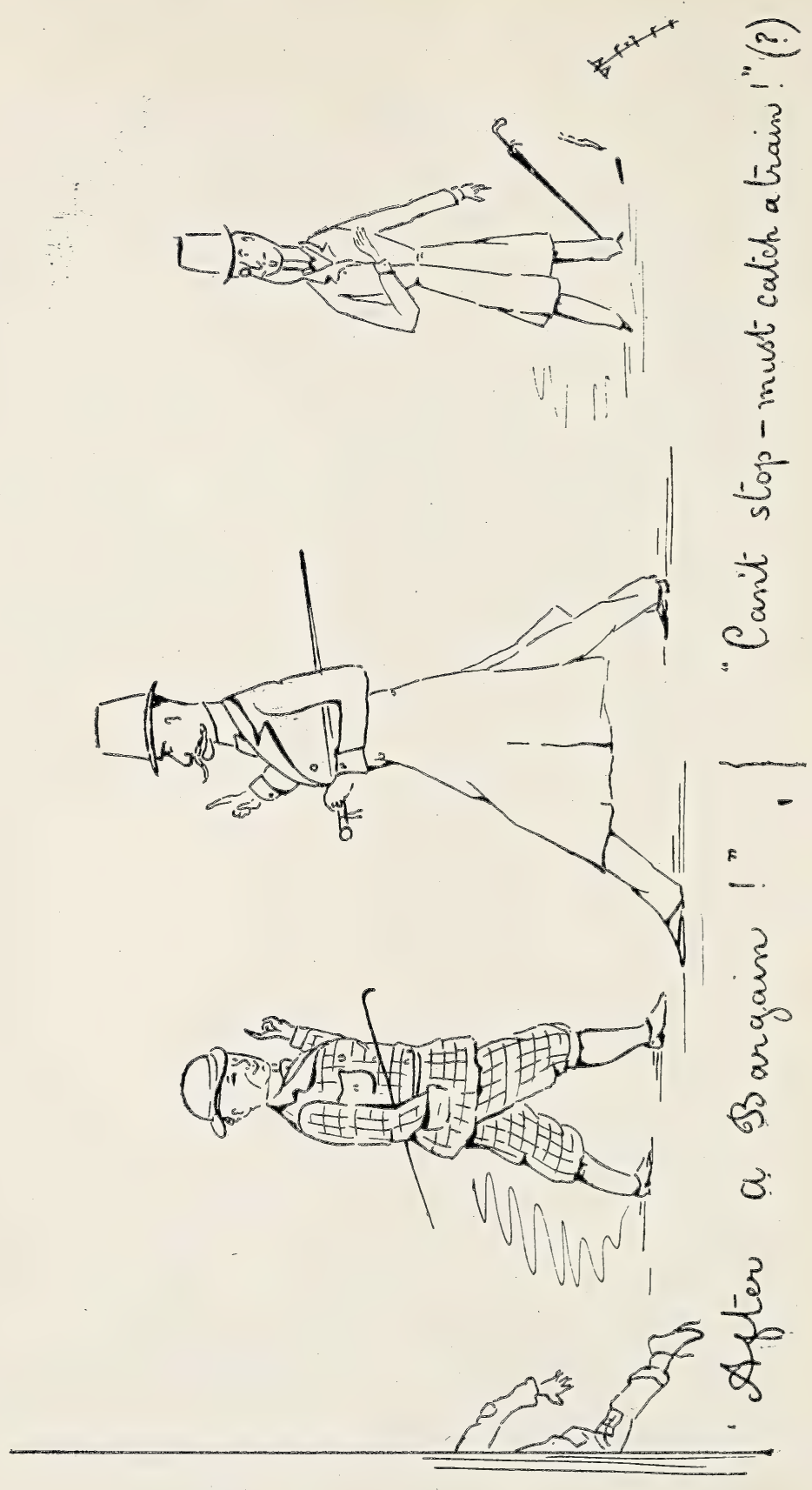


He glanced behind, as thus he challenged me, And I obliged and with alacrity,

With me his trail on it were vain to fly-

The finest sprinter in The Blues was I.

To track, not capture, now I used my power, I shadowed, dodged, and scouted like a Boer; Who held the Cape I'd hold in view, at least, Tho' I a dance were led from West to East.

We passed the Fleet, Lud's Hill and down Cheapside, Phils I encountered, but not one who tried To stay me, for I made the sign that reads "After a bargain!"- -which no vain words needs. Others, and Philistines, I let remain Their ignorance in-_" Can't stop-must catch a train !" The City boundary reached, we crossed the line That Aldgate's ancient pump doth yet define.

Across the Eastern frontier now we passed, (The Eastern question would be solved at lastAs far as Stamps went) on the quarry sped, [tread; Down Houndsditch went the hound with quickening A turn and shoddy Shoreditch did we gain, (You know the "Ditch" named after jaunty Jane)

Then Spitalfields, the home of weavers deft (This time was Jim the weaver-I the weft!)

A darksome passage then he bolted down, He seemed to like my chasing him, the clown!

I should have set a thief a thief to catch.

("But you for any thief, Paul, are a match!") 
Within an old shop Jim did disappear,

I followed, then his game to me was clear,

For, as that store I entered, sharp and quick

The door behind me closed with ominous click!

Trapped and in darkness, for the light went out

As I went in-the haunt of thieves no doubt, P'r'aps Death to meet. Before who wears the cowl

I ne'er yet quailed, and now set up no howl.

Let Death make this my last stamp-hunting scrape-

Life was not living worth without that Cape!

I lived for Stamps, and, if my time were due,

I for a Stamp could die-die like a "Blue!"

Darkness like night, then bright electric light

Flooded the scene; it was a curious sight

That met my eye-a dozen men or so

From sacks capacious heaping were "ole clo" "

A counter long upon, at whose far end

Sat one whom to describe I don't intend

Just now, but do now what I did just then-

Note the apartment and ignore the men.

Hung from the cross-beamed ceiling many a row

Of garments mixed, ancient and new " ole clo,", "Bags" such as e'en on M.P.'s legs one meets (Some, like some M.P.'s once, had lost their seats).

Next to a Court dress, and, as if to mock

Its faded glory, hung a carter's smock,

A cloak that had some grande dame's shoulders seen

Next to the jacket of some " coster-queen," 
The old "Newmarket" of some sporting card (Whose loud pearl-buttons racy tales had heard), Not clothing only, pictures there were hung, Old Masters-looking strangely fresh and young,

Old furniture, the real thing - and what's not, Many a "faked" with many a genuine "lot," Such as the wary and unwary meet With in their hunts-maybe near Wardour Street.

I'd been decoyèd by the Cape boy "slim," Who switched the light on, and who'd "doused the glim," Who'd turned the key when I the den turned in, Jim after all as artful was as sin. "Will you step to the far end for a word With our boss there?" I answered, "like a bird!" I love adventure, such was promised when Stood Paul Jones face to face with "Birdcage Ben."

My hand the giant in his own did take In vice-like grip, and I returned the "shake" With interest (my grip's a clincher too). Ben let go, saying “ That, and you will do! Much have I heard of you, and I respect Your business methods, in which I detect The trading genius-this I've learned from Jim Thro' the few dealings you have had with him."

Clean cut the features, and the face clean shaved, The face of one who had the devil braved To gain his ends; but not the face alone Claimed my attention - as I'd claim your own 
Whilst I a startling statement make and true,

What think you wore the herculean Jew?

Guesses are vain and from the truth remoteWore Birdcage Ben my uncle's gray Fur-Coat!

* * * * * * * * *

I like surprises, as " surprises" go

("That's Christian like - after De Wet and Co!"), And I showed no surprise, but caused Ben such By asking, just as I speak now, " How much Will you take for the fur-coat that you wear? I know from whom you got it and from where That party got it, too!" Ben's glance did slide To Jim, who pale turned and then turned aside.

O Blood-red Cape, art thou my guiding star! O bluff, your aid, you've saved me, bluff, thus far! “It fits you well, but, friend, take my adviceFor I know all - so let me know your price For that fur-coat!" Big Ben now played his game, "I'll think it over, then my price I'll name. It's not of coats, but stamps (poor fool!) I'd speak, (Bring glasses, Jim!) an expert's aid I seek.

No matter how, you are well known to me, And we can each to each most useful be, Your health!" and then Big Ben laid bare his scheme (The Jew's mind full was of an empty dream!). 
In his own "line" this prophet naught dismayed, As great there as the profits of his trade.

Of Stamps, tho', Jew like, naught he seemed to know, That Jim he trusted gave away the show.

A valuer keen was Ben of aught that came His way - excepting Stamps, they're all the same These Hebrews, whilst a Christian ("Such as Paul!") What they perhaps know nothing of, knows all. This fact Ben recognised-but hear him speak Himself for, and his verse was far from weak ("Compared with yours, Paul!"), in its truth, at least, Tho' different from most poetry of the East. 


\section{VII.}

\section{An Unḩoly Alliance.}

"Well-known stranger from the West, you are welcome as our guest

(Should your ' gentle grip' well fit you for the East),

We have heard of your renown as a champion 'bater down,'

And your 'slimness' we don't question in the least.

Simple dealers in 'ole clo', we of Stamps but little know,

What we know I fear is hardly worth the knowing,

But our friend here, Pedlar Jim, says that you're ' uncommon slim,'

And, as we find the trade in Stamps is growing, We'd like a nibble-just to feel that we are in the swim.

Jim knows a bit, but you know just a trifle more than him!

Now with Stamps, you will allow, it is strange that up till now

Have we Israelites aloof stood from the trade,

But our Jim who travels West tells us what we'd never guessed-

That fortunes daily in the biz are made;

This biz, alas! 'tis true, is neglected by the Jew,

In spite of our stamp-sources we've not tried 
To push this business new, like the pushful Christians do

(Methought the Hebrew "like a Christian " lied!),

Tho' as a race, behind the times-I have myself no doubts That we, if only taught the trade, could learn the ins and outs.

There's in every mortal thing, that is, every trade-a 'ring,'

You can't break up those ' rings' or get inside 'em;

There's, of course, in Stamps a 'ring '-for, you bet, we've learned a thing

From the trade - a thing or two-because we've tried 'em.

Who'd help us do the trick must introduce the pick

Of Philatelists, or Stamp collector-dealers,

You, of all men, know the crowd, and you can, if not too proud,

Find the motive of my philatelic feelers.

The dealers hate our class, and here's the cause of all their pique-

Our opportunities for getting Stamps are quite unique.

Have you ever thought, sir, where half the stamps described as rare

Come to light and constitute a glorious ' find?'

On old letters?-Yes, no doubt, when some hoarder turns 'em out,

But the while they're out of sight they're out of mind. Long forgotten and remote in the pockets of some coat, Irong consigned to lumber-room those letters lie, 
Till our ancient cry 'Old Clo'!' lets the thrifty housewife know

That 'some fools will any kind of rubbish buy!'

As a judge of human nature you, I know, this truth know well-

Women rarely search the pockets of a garment ere they sell.

That's of course where we come in, and we reckon it's no $\sin$

When we buy ole clo' to stick to all we find

In the pockets-or the lining (was the speaker's eye now shining

With a light that spoke of something he'd in mind?)

What we find you'd scarce believe-tho' I can't hope to deceive

One so worldly and so resolute a rover,

But in watches, diamond rings, and in such like trivial things,

It would turn your head to hear of our turnover.

To stick to such may, in your mind, stamp all of us as scamps,

Tho' you yourself would stick, I think, to all you found in Stamps!"

To the speaker's coat my eye then attracted was, and I

Thought the Hebrew's followed mine with stealthy glance.

Was it fancy? Yet, I think, he the other eye did wink, Or in the eye unwinked did mischief dance? 
What a fool he was if he thought of crossing swords with me,

For my "play" to parry needs a skilful hand.

Had I found the coat too late?-I could only watch and wait,

And the waiting game is one I understand.

If foiled at first did I resolve, whilst hearing "Birdcage" talk,

That I would strike, and when I struck-a ghost would "Birdcage" walk!

"If we clear out some M.P. of his cast-off toggery,

Of such ' lots' we often find some treasure each in,

Big bundles say of notes (No- not Bank of England notes),

In the pockets of each coat he's made a speech in.

On the backs of rare 'entires'-such as every Phil admires,

On Mulreadies (tho' that stream's now but a dribble), You'd hardly think what quires for its "notes" a speech requires

(Or what awful rot and drivel M.P.'s scribble!)

Such, of philatelic findings, is a source we long have tapped,

Whilst the dealers at the auctions merely bid, or yawned, or napped.

Only dealers in ole clo' in position are to know

Where to find the sort of Stamps stamp-dealers covet, To this truth we're now alive, and in time we hope to thrive

On our knowledge - if you knew our biz you'd love it! 
Wives who sell their husbands' togs, as they would their bones and rags,

Lack what woman mostly lacks - that's curiosity, And to go through cast-off ' bags' seldom any woman fags

(Tho' she'll 'go through' present wear ones with alacrity!).

Of unused stamps and obsolete we thus secure a host

On letters careless husbands years ago forgot to post.

Some were letters of their wives-but to other fellows' wives

And to single ladies, too, their model hubs

Letters of their own forgot; and I make of cash a pot

When my (black) mailed fist goes round collecting subs. They fetch prices big, of course, in a big case of divorce,

Half the letters read in Court are from 'ole clo',

For my ' lots' oft find a place in a breach of promise case,

Tho' my terms are high-as rival counsel know :

And politicians oft I catch, when they ' change' coats or trews

The letters in whose pockets show how they can change their 'views.'

Now waste-paper's had its day, tho' 'twas once a 'line' to pay,

But as far as Stamp 'finds' go it's now played out, It's of time and cash a waste buying City Office ' waste' City clerks know far too much, there's not a doubt, When from office boy to 'boss' to the philatelic joss Each bows the knee, for each is a collector ; 
There's no 'finds' in Bankers' 'stuff,' for they know more than enough,

From the porter to the managing director.

To clear out any 'clearing house' I'd not now give a thank,

To name one worth the clearing-well, I do not know a bank!

In old furniture, of course, we've a never dried up source, Many hoards of stamps long obsolete (with gum)

In old drawers are stowed away and ne'er see the light of day

Till some secret spring obeys our expert's thumb.

Many a Stamp-sale's choicest 'lot' in this manner has been got,

Tho' the auctioneer the kudos gets alone,

Many a fortune make he can, for the lucky middleman

Ever reaps the harvest other hands have sown.

We want one like yourself to sell our stamps and act as buyer,

An expert at the game, and (no offence) a champion liar!

Now to business, sir, we come, and I wish to drive it home

To your mind the sort of post to you we proffer

To a keen Phil like yourself, one to whom (apart from pelf)

Philatelic fame alone's a tempting offer !

For a company we've made of the 'ole clo' -stamp-brigade,

Called 'The Phils' Own Limited'-you understand? 
And to-night we start the game (happy omen in the name !)

At Phils'-buildings-that's in Houndsditch, not the Strand.

We to-night will hold a Stamp,sale for your benefit alone At I'hils'-buildings, well-known stranger, where our Stamps will all be shown.

No Philatelists are we, tho' I've just picked up, maybe, What you'd call a little philatelic pattering,

We rely on Pedlar Jim, but, I'm speaking now for him,

Of the subject he himself has but a smattering.

Jim's a shy, retiring cuss - which applies to all of us

(I'm the spokesman now for what we all would say),

He's no hand at putting feelers-as for dealing with the dealers-

Like his name's first letter, Jim's a perfect ' jay,'

$H e$ should have known (if we did not) the penalty incurred In selling postage Stamps without a licence, on my word!

You hold the winning hand, but I think we understand That the situation's one for compromise, If this the matter squares-a hundred preference shares In our company-you're welcome, tho' they'll rise!

In return, of course, you're mum, re the licence you'll be dumb,

Sign this deed, but take a minute for perusal,

Do not mind this blade of mine, but in blood you'll have to sign!

We can take your life-but can't take your refusal!" 



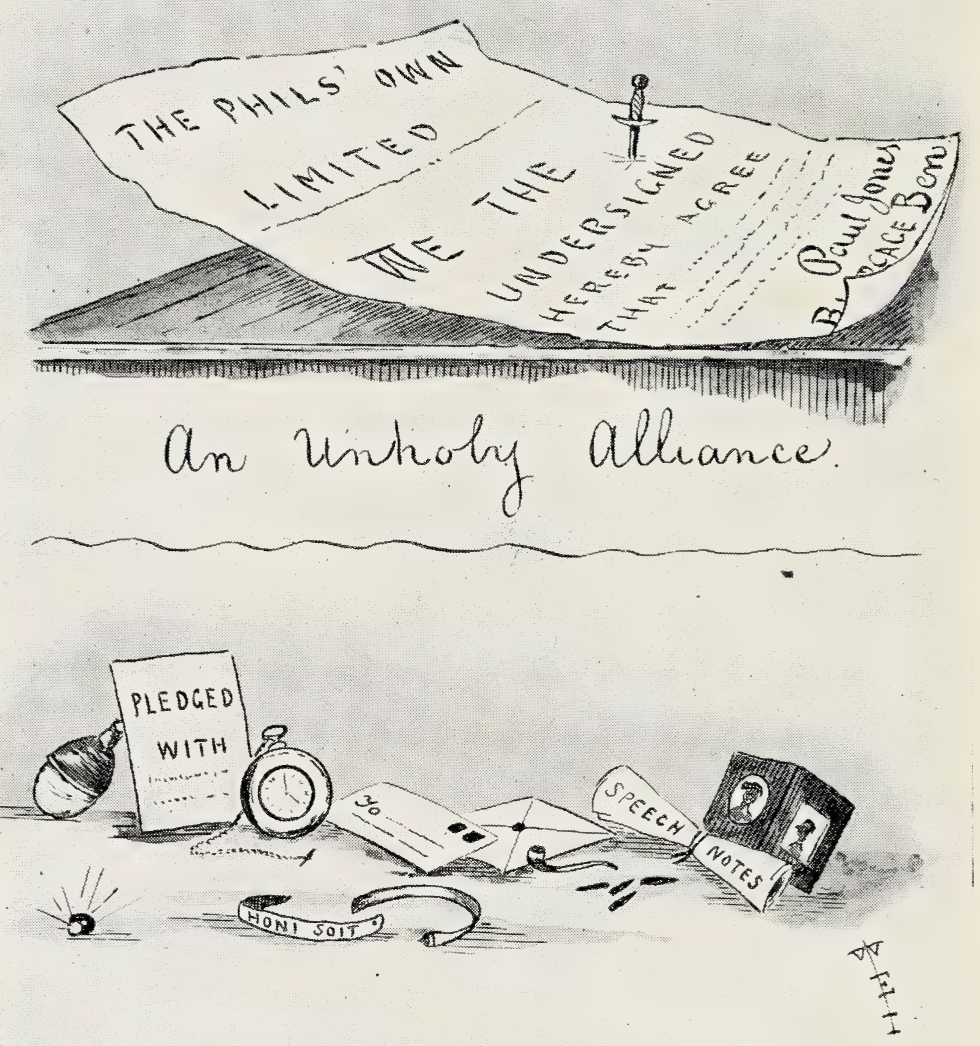

Average "find" in an "ole cleo (gents) suit. 
“'Twas signed, and May the second I remember by this scar,

You know its meaning now, Will!"--and the Stamp-fiend laughed, Ha! ha!

* $\quad * \quad * \quad * \quad * \quad *$

“Phils'-buildings justified its name that night, P'r'aps I the first Phil was to catch a sight Of this strange spot, for Stamps the queerest pitch, E'en to buy Stamps what Phils would dare 'The Ditch'?

A large, square yard, high walls closed in the Square,

'Cross which ran benches fixed, both long and bare, $\mathrm{Had}$ each its roof, and 'twixt the gaps the stars

A scene viewed that description only mars.

And at the entrance to this eerie square

Stood a night-watchman sort of pay box where

The fee of three-pence charged were all who'd try

The yard to enter or to sell or buy.

An ole clo' mart converted for the while

Into a Stamp-bazaar. Ah! you may smile,

But all the leading Stamp-sale rooms combined

Such 'lots' could ne'er produce as there you'll find!

This first sale was my 'benefit' to be, Great Scot! indeed it benefited me, At this sale I alone could make a bid, Buy at my own price, too-you bet I did! 
I took by our agreement (signed in blood)

Stamps to my value of a hundred 'quid,'

I claimed this right (for I feared 'bulls' and 'bears')

In preference to the hundred preference shares.

Don't ask what ' gems' I bought, the long list might

Well tire you-but you'll see the grade to-night

Of those Stamps which (I don't their value stretch)

Would, in the open market, thousands fetch!

The sum I spent I deemed was quite enough

'To give of prices an idea (tho' rough)

To my confreres, for I'd a promise made

To 'teach them how to bargain with the tade.'

As ' fake detector' they'd appointed me, Their lots, so far, contained no forgery, But I as forgeries did confiscate

Scores of Mauritius from an early platè ;

'To offer such for sale,' said I, ' would bring

Discredit to and p'rhaps break up the 'ring.'

Then how to 'tell' such fakes I told poor Jim.

'Twas our first sale-and saw the last of him!" 


\section{VIII.}

\section{TIhe Clape-Cryime.}

"Listen! and you shall hear what none have heard Ere this, you take my word - and give your word That none from you what I to you now tell Shall hear !-you hear and promise?-Well, that's well. Draw closer to the fire, the air strikes chill (I would to-night, Will, that I'd made my will). Now you shall hear (well might I look dismayed!) How came I by the Cape of nameless shade!

Mine (for a Guardsman's!) is a simple life, Wedded to Stamps, and faithful to my wife, Old fashioned, and behind the times, of course, For I ne'er change my love nor seek divorce. Fond to a fault, the truth I now will tellMethinks I love not wisely but too well, This bitter-sweet truth I no longer doubtMy love for Stamps my one crime brought about.

* * * * * * * *

'Twas midnight! In the square, with lantern dim, (The rest had gone) with me stood Pedlar Jim. This time was I the weaver-he the weft, For luckless Jim, my right hand man, was left. F 2 
Left to my mercy?-why say mercy, pray?

Jim owed me something - and I made him pay:

I gave no order (or I'd ordered crape)

'It's cold to-night, Jim, and-I want your Cape!'

Deep silence reigned within 'The Ditch' retreat, (Soon broken by the sound of flying feet!)

Two shadowy forms stood there-and then but one, My right but struck one blow-the deed was done. Hark! as I strike, Big Ben the midnight chime Strikes-to make this my first and only crime. Conceal the body - Why, what need for that? But p'r'aps you've never seen a Houndsditch rat!

What passed between us? For his Cape the rogue My price refused ('twas not full catılogue I own) but how could I my temper keep? For 'woodblocks' were (at one time) very cheap. Had I paid much, I dreaded much to think How that ' $f l y$ ' pedlar would but fly to drink; E'en with the sum I offered him, a 'bob,' Men in his walk of life run to the pub.

Who know me will the deed take for the will, But, tho' I struck, I did not strike to kill ; One fact acquits me, tho', as I foresaw, It would not in the eyes, p'r'aps, of the law. This my defence, my only one and bestI killed that pedlar at his own request! For he said 'Strike me if you ain't a snide!' And, as I ain't, I struck him-and he died. 
Now for the snuff-box-what, you've heard enough?

But say, what can a dead man do with snuff?

'Sneeze at the devil ?'-Yes, I like your wheeze,

For Jim had got a devil of a sneeze.

If I took not his talisman, poor chap,

I from experience knew just what would hap,

Some common thief the precious Cape would pelf-

I know their ways, so took the box myself.

Then from the box I took the Cape, when, lo,

E'en as I looked at it, did brighter grow

Its shade! When first 'twas shown me, be it said,

It was a healthy, natural, pure Stamp-red,

(Tho' a rare shade) but when I laid Jim low,

A bright blood-red the tell-tale Cape did show!

Why could the 'Experts' not the cause divine?

Some of them get rare Stamps as I got mine!

And while poor Jim lay dead I stood alive,

How true it is the fittest must survive;

What was his life, the poor hard life I'd freed

From this o'ercrowded City, what indeed?

Yet I-my nerves are far too highly strung-

Felt by the sting of conscience deeply stung.

To cut it short, altho' I used no knife,

I for a ' woodblock' cut the tree of life.

He struggled not so much as I have seen

Some pedlars struggle - as some would I mean!

I noticed that his breath had ceased to come

By the strange absence of the fumes of rum; 
I saw at once, tho' this was my first ' kill,' That he was dead-altho' he lay so still. And there is comfort in the thought, as such, Tho' he died hard he did not suffer much.

Jim made no protest, even to prolong His life- - he felt that he was in the wrong, For me no word of censure nor of blame, He fell and silent lay for very shame. He recognised that I was but the tool That had, to serve 'The Cause,' to kill a fool. The blow I gave him did not kill him, tho', For I swear that he died without a blow.

Had he some reason shown might I have shown Some mercy, but stern justice claimed her own ; From some, if not from you, I'd earned applause, Self was his god but I struck for 'The Cause.' The dead speak well of - and I think I can, Jim died, I must say, like a gentleman.

He died, p'r'aps hard - yet no hard word was heard Upon his silent lips, upon my word!

Had he a mother, brother, sister, wife? I took no count-I only took his life; Had he a wife e'en her he might have tricked, And now he'd gone might she no more be kicked. As for the rest, most relatives, you know, Don't care a button for those gone belowOr gone before. (Was this Paul's afterthoughtWho took the pedlar's life before he thought?) 



'Why not have made him One of Us?'- Would you Teach such a one the 'wrinkles' that you knew?'

Pig-headed views I, as a rule, don't nurse, But from a sow's ear you can't make a purse!

Better to lie, e'en in a pauper's grave,

Than live a spendthrift-Jim could never save, He a poor chance in life's stern battle stoodWeakened by drink, and p'r'aps improper food.

Could I have led him, as I tried to lead, He had been spared his life and I the deed, But to reform him were a thankless job, A man who'd quibble o'er a wretched 'bob';

A thankless job is dealing with a class

Cursed with the vice of the proverbial ass, With such to reason is a hopeless task, From asses always take and never ask!

And ere I left the man whom I'd 'removed' I ruminated and the truth I proved Of the great theory, in its truth sublime, That motive is the measure of a crime. The rogue of profit sought an undue share, The Cause to him was naught-he didn't care; I, who can selfish motives overeome, Struck for The Cause- and then I struck for home.

* * * * * * *

The news, when old, would reach New Scotland-yard (Since my ' mishap' of many such they've heardMen of Jim's class, who seem for trouble built, There oft report ' Another pedlar kilt!'), 
Then in a year or two, or less than that, When all the town for long had 'smelt a rat,' The carrion would (for justice presses hard) Be scented by the sleuth hounds of 'The Yard.'

They'd sniff around the ole clo' mart and-ha! Sample the beer in the adjacent bar, Ask the plump bar-maid if she'd heard a scream, And, if she'd dreamt she had, ' take down' her dream. They'd say 'This job the work is of a gang,' Find evidence sufficient scores to hang, They'd also find and measure (with red tape) A blood-stained coat-but not a blood-red Cape!

The anniversary of that night's work Brings forth, they say, the pedlar's ghost to walk Phils'-buildings, but a ghost, lad, of to-day No chance has whilst new 'Bodies' hold their sway, For such pull ancient institutions down, Their aim's of all romance to rob the town ; E'en ghosts require, if ' walking' ghosts they'd be, A special licence from the I.C.C.

What came of it? - Why, naught, am I not here? Whilst Pedlar Jim is-you can guess p'rhaps where! Bolt : Not a bit of it - my plan was 'slim,' I called next day on Ben and asked for Jim.

But none knew aught of him whose mouth I'd stopped, In Parliamentary phrase 'the subject dropped,' Not so the stamp sales, I still bought from Ben For phantom clients of the upper ten. 
But once in three months were these weird sales held

Phils'-buildings at, no other sales could yield

Such grand results-for me, for I took care

(Trust me !) to be the only bidder there;

Of risks, and great, so I informed the Jew,

In the illicit trade I ran no few ;

Of stamps I bought for twenty pounds or so

Three months' accumulations from old clo'.

Then came the call to arms, and at the call

Forgot I Uncle Joe for ' Uncle Paul,'

Ben's contract was, the while I'd laurels earn,

All stamp sales to suspend till my return.

And I returned three nights ago, since when

I've cleared the way for clearing out Big Ben,

We two to-night the sequel to the tale

Will work out at the Stamp World's Record Sale!

What of the fur-coat? 'Birdcage' wears it still,

And still, at any price, declines to sell;

Mark me!--e'en murder may its theft define,

Such villains will at nothing draw the line!

But, bluff or bribery failing, will we fight

And take by force of arms the coat to-night.

All is prepared, Ben but commands a crew

Of aliens-I the British born, tho' few !

They say conscience makes cowards of us all,

But what is conscience-is it spleen or gall ?

Bred in the mind, but mind you, even so,

Make the mind easy and the scourge will go; 
But, as the body e'er affects the mind,

See to the body if relief you'd find.

Freed from the pangs of conscience would you be ?-

Look to the liver and you'll all be free!

You've heard my tale, an awful tale maybe

To those fireside-Philatelists who see

The Stamp World from a narrow point of view,

With such poor creatures I don't number you.

The blow I struck the kindest was of blows,

But, tho' I care not if the wide world knows,-

Keep to yourself, and keep it for all time,

The long kept secret of The Great Cape Crime!

* * * * * * *

Now say, what think you of my first defence

In this, my first crime and first murder 'case'?"

Said I: "You've played the part and played it 'big'

Of prosecuting and defending wig;

Trained for the law a greater name you'd made

Than you can hope to make in the Brigade,

The Blues would say, had you they heard thus far,

That their gain was a great loss to the Bar.

This your defence," said I, "I much admire

For subtlety and eloquence and fire,

But $\mathrm{O}$, to think that you, my friend, have need

In such a case your own grim cause to plead! 
Think not that I would moralise or preach In telling you that such a telling speech, Made in a worthier cause, had brought you fame, And leading lights of counsel put to shame.

But I've a duty which I must perform, Due to society, which would raise a storm of condemnation and e'er stand aloof From me-did I too lightly let you off. To reprimand you is my duty clear, And sterner measures are demanded here; Mere rhyming verse the strain will never stand, Tho' rhyme and reason's in my reprimand.

I'll speak in blank." Paul answered, looking blank,

"I can't the point see, and refuse point blank

In blank to hear you - why not stick to 'rhyme'?

I see no reason for your changing time."

Said I, "No reason's there in rhyming verse,

I'll speak prose-poetry, intense and terse."

"Go on!" said Paul, who deemed 'twas "nonsense rank"

What he profanely termed my "blanky blank." 


\section{IX.}

\section{Bubble and Squeak.}

"Hear thou my reprimand!

The gift of language that some men possess

May e'en prove fatal to the cause they plead,

When the wild eloquence of glibsome tongue

Leads them astray - the hearer, too, confounds.

I who have heard the paralyzing tale

Of this, the which you call your only crime,

Sit paralyzed, for I, alas! ne'er deemed

That human guile to such depths could descend.

In this, the early stage of your remorse,

I would not add one ounce weight to the load

That rests your conscience on-if one you have.

If one you've not-I envy you nor blame,

But who can hope of conscience to be free?

Call conscience ' liver' if you will, yet I-

Who have a liver-never feel its sting.

'Tis something more, for I will ne'er believe

The inner works of this, the body gross,

Control the workings of reflective minds.

I doubt your story not, I know you well,

And, knowing you as well, Paul, as I do, 
The main fact I believe, altho' I find

Some inconsistencies pronounced and clear

In the recital of your gruesome tale.

One fact remains - the crime you call your first,

Tho' for a Stamp committed, is the worst.

(Lest you the point miss in the point here made-

I bring the rhyming couplet to my aid.)

Say, where's our boasted love of liberty,

Our sense of justice and equality,

If crimes like yours, tho' stamp-crimes, be allowed

To go unpunished? We Philatelists

Are Englishmen, if stamp-collectors, first,

And tho' a pauper's life might stand between

Ourselves and some rare 'gem' we long had sought,

I say, and seriously, that some, at least,

Would deem that life as precious as the Stamp.

Taking a broad view, e'en a pedlar's life

To him is something worth, and one who takes

Such life incurs responsibility.

(Tho' if he has the murdered man's consent-

And this you say you had-the crime is less.)

Some men of your sort, men of war and strife,

Take no civilian's view of taking life.

Just think what follows if it once became The fashion-taking life to get a Stamp !

Who would be safe? Stamp-Fiends would not confine Their 'operations' to the lower ten ; The turn of men like you and me would come, For hundreds of specimens have we 
To justify, I think, as many crimes,

And who are we that we should lose our lives?

Britons, if overtaxed, at least are free,

And we respect the law-and fear the police,

Despite your strictures on New Scotland-yard.

Here we collect what mortal thing we like,

Honestly sometimes-but we all 'collect'

(Have other hobbies their collectors' crimes,

As I'll endeavour, later on, to show).

England, I think, can favourably compare

With other lands ; can Englishmen at least

Collect all countries safely in their own.

I live, tho' South America's my ' lot '-

But then I don't collect them on the spot!

We have warm hearts despite our Arctic clime,

We who inhabit this frost-bitten Isle,

Our 'Gentle Spring' e'en fails to freeeze within

Our breasts the springs of charity and love.

But one might deem within your breast those springs,

Tapped at their source, for ever were dried up,

Tho' time was when such springs (unlike our clime's)

Within thy breast as fountains free would play,

And now-not e'en a tear bedews the eye

That once for others' woes could torrents weep.

Say-whence a change so greatly for the worse?

The unnamed cause of this strange, causeless change

Beyond the ken of most poor mortals lies.

I know, altho' I hesitate to state

The cause-because The Cause itself's concerned! 
The Goddess we revere perchance may smile Her calm approval of the deed you wrought, And, if she smile, disloyal 'twere for me, A mightless atom, to presume to frown. Yet doubt I if e'en Philatelia smiles In full approval of your cruel Cape-crime.

She claims Our homage, yet, to reach her throne, Would she desire that we should wade thro' blood? I cannot think that she expects so much, But deem that murder she regards as such!

Now will I cease to preach The philatelic pulpit from, and read A lesson in the lesson you have read This night to me, that I may pass it on ; I cannot pass it by, for that might seem That I condoned the Cape-crime (which I don't), Or recognised a virtue in the crime, As a philatelist - as some would do.

What you have done you did; what I have said I said because I said I'd say my say.

You go your way, and I my way will go, The world is wide and room provides for allSave luckless pedlars. Should I ever meet A weakly member of that tribe, who holds A Stamp with which, for cash, he will not part, I don't say that, if feeling fit and strong, I might not do the thing I may not do! This kindly hint, intended too as such, I drop for you -as I would drop for him! 
I would not have you think that I condemn

Too readily or harshly your ' mishap.'

Already do my feelings seem to change

Towards you-when I think what you went thro',

What trials and troubles, tribulations sore,

To get possession of the Cape you hold.

I thro' as much had gone-I do not say

That I had gone as far-but, there, who knows?

Pursuit of science oft may lead to blows !

And now, a word of hope.

Think not confined to Our Pet Pastime are Such 'incidents' as this that you describe, For undiscovered crimes - if such you call Such 'incidents,' in very truth abound, And well are known to every votary Of every other fad, apart from Stamps. The Bibliomaniac in his search for books, The mad, wild hunt in which such cranks indulge, Will do-I know not what he will not do To add some 'treasure' to his useless hoard!

If but the stalls in old Booksellers'-row

Could speak-(they can't because they're now pulled down)

Grim tales of terror, I believe, they'd tell To dwarf the horrors of the tale you've told. Ah! many an old, if harmless ' maniac,' Who spends much money on some trashy book, Is tracked, or has been tracked from that dark spot By some collector, just as keen, who lacks 

The greatest source of crime. (A warning to the numismatist)
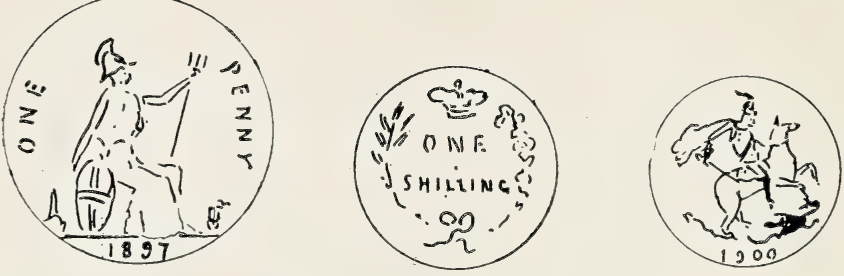

a"brown" - a" bol" - a "quid".

The Awful Ornithologist



The human vulture lira of prey That preys upon our birds. 
The cash wherewith to buy books ' on his own,'

But shadows him who just ' got there before,'

And in the devious labyrinths of 'The Lane'

Relieves him of his purchase-and his life!

Yes! you may look incredulous, but I

Believe such things are very often done,

Not hourly p'r'aps, but many times a day.

Now you would ask - I see it on your lips-

How is it that such eases don't appear

The columns of the daily papers in ?

The Trade combine to bribe the press and police,

Whilst on the subject they themselves are mute-

Lest brought the book-craze be to bad repute.

As for the Numismatist, say-

What can you say for one who would amass

Base coins of the realm-and other realms

O'er which his own liege sovereign holds no sway?

He's a 'collector' of the deadliest type.

To miser-minds this fearsome fad appeals,

Such minds unhinged become thro' lust of gold.

Others will only current coins collect,

And bank them, to the detriment of those

Who don't or can't collect. A poisonous branch

Or offshoot rank of this, the mother craze,

Is that for antique coins kept in trays.

Crime's rampant here - ask Sotheby, Lincoln, SpinkYou'll shudder if they tell you what they think!

(A member of the N.S.L. told me

That 'Ne'er spare life' their motto ought to be!) 
Ne'er since the world began (if not before)

Did any craze such riot run as this,

Or breed such murderous tendencies amongst

The sordid weaklings who espouse its cause.

Coins we all must have (or wish we had)

Wherewith to live, wherewith to barter, buy

The bare necessities of this cold life.

There should it end. The accumulations vast

Of ancient coins serve no useful end,

You cannot spend them-and you dare not lend.

Half of the crimes committed-nay, not half, But full ten-twelfths, at least, of these same crimes Are due to the insatiably long thirst For gold or silver-aye, for even bronze. The company-promoter who promotes Schemes to promote our welfare-or his own, He, like the three-card-tricker, lives by crimeJives on the unearned increment he ' earns.' Now leave the Kings of Gold, and Silver Kings, And lower look to find the men of bronze, Who, for the price of what they call a ' pot,' Will take a life-and yet we wonder not!

What of the Ornithologist?

Birds of a feather his peculiar class, Who from the vice of killing are not free.

A bird in hand (an Ornithologist's)

Is not, indeed, worth two birds in the bush, For one live bird is worth a dozen dead- 
A fact to which live birds are quite alive.

In taking birds he needs must take their lives, That's bad enough-but does he stop at birds?

I in my time have seen and travelled much, Have deeply studied every stamp of man, (Tho' Stamps themselves I've studied deeper far)

And I've met men, who prey upon our birds, Who are such human vulture birds of prey That stood some rara avis and their grasp A human life between-it sounds absurdThey'd take it, yes, and take it like a bird !

\section{Do I except Ex-Libris? No!}

Of book-plates, and of bookworms that collect Such plates, I can't with patience speak. Alas!

My patience lost was when I lost my booksOr; thus to put it, were my books not lost

But gone before I could recover them. (E'en those remaining need recovering!)

Lent to my friends - there's cant in both the terms, For 'lent' means given - to distorted minds, And such minds did my so called 'friends' possess. Let the bare shelves around my library Speak eloquently in their emptiness, For they speak volumes of the volumes goneI know not where, for breathes no man that knows The bourne from which no 'borrowed' book returns.

What was the value of the books themselves?

I knew not, cared not, nor did I enquire, G 2 
'Twas for the book-plates in them that I loved My books-but others loved those 'plates' as wellToo well-yet wisely-for they sneaked them all! They borrowed (so they termed it) books from me, Then, having ' borrowed,' burrowed for the 'plates' That hands, long cold, had in those volumes placed. Did these base knaves relieve me of my ' Jacs,' They skinned my books, alas! of 'Skinners' rare, And tho' no mole-hill I'd a mountain make, I to this day must mourn each 'Mountaine' missed.

'R.M.' meant ready money in their case, For my 'R.M.'s' were worth their weight in gold. What did they say when taxed the taking with?

What could they say, but what book 'borrowers' say When brought to book? Some were too hurt to speak, Others too timid-they were all too proud My volumes to return without the plates!

With books lost I my 'plates' - with 'plates,' my 'friends' ;

Of those who such plate-onic 'friendship' showed Some deigned to speak, and thus, in tones most cold, 'Your books I either lent or lost' (or sold?).

Ex-Libris-bah! I hate the very name! Would Exit 'Libris' better fit the case? I'd hack it into chips, could it be hacked, With those who took my 'Hacket' and my 'Chips,' (My 'Hacket' too, with head without the frill!) Nothing would tempt me now to touch a 'plate' (Save with a knife and fork), for 'tis not meet 
That I should others' leavings deem a feast.

Did Dorman show me e'en an Igler 'plate'

He'd fail to rouse me from my dormant state!

Now for the Botanist!

The gentle Botanist, at least, you'd deem

Free from such crime; the outdoor life he leads

Does not imply that he takes life outside.

Here the fair sex a fair share undertake

In the wild, weird pursuit of vagrant plants, And oft strange 'errors' find in Nature's growth.

Is she, or he, above suspicion quite?

Fain would I question-dreading to reply.

Brought to my notice once was there a crime, Which proves that, when botanical her mood, And in pursuit of this, her floral fad,

Woman can be as pitiless as man.

I'll tell the tale, a tragic tale-but, still, Romantic - a botanical idyl.

(I'll hie me back to ' rhyme,' for this, I think, Is not a subject suitable for ' blank.')

\section{THE MARIGOLD.}

\section{(A Botanical Idyl.)}

Two sisters they, who started out one day,

With vasculum (and pabulum) equipped:

(Sisters and Botanists, I ought to say)

Across a Midland County moor they tripped; 
So high their spirits and their mood so gay,

They laughed and sang, they even danced and skipped;

They hoped to find, 'twas found there, they were told, The rare Mongolian Magnum Marigold.

Bookworms were they ('worm worriers,' too), nor light

Their reading-heavy reading, tho', repays ;

O .ida, Corelli, ne'er for such did write,

Bentham and Hooker charmed them, tho', always.

'Lumpers' were both these maids of figure slight,

(Tho' fashions come and go, the corset stays.)

'Hair-Splitters' they were not, for they were boldAnd called a Marigold a Marigold.

They'd never found a specimen, altho'

In search for one they'd tramped I don't know where.

(I've ne'er found one, but, if I did, you know,

I shouldn't know if it the real thing were.

This by the way-'tis strange that folks should go

Long tramps such very trivial ' finds' to share,

'Tis odd how some take up with Botany,

Mere waste of time-while there's Philately!)

They loved a plant, as ne'er they'd love a man,

Intent on Science they, no fickle flirts.

E'er undivided worked they, walked, or ran,

Their 'finds' divided were (so were their skirts). 
Advanced new women, with no worldly plan

Such as from Science oft a maid diverts,

A nobler ambition theirs, I hold,

Than that of maids who'd win and marry gold.

They roamed that rugged Derby moor and wild

(I hope I've fixed the right locality,

For in such matters I'm a perfect child-

Show me a Stamp and I'll say what it be!),

In disposition gentle, meek and mild,

Say! what could rouse their animosity?

'Tis passing strange (I tell what I was told),

But marred their merriment a Marigold.

Had each a fine collection, in its wav,

Of plants (the use of which I fail to see),

They shared and shared alike as-let us say

Would Stamp-Collectors, as you'd share with me.

They split their floral duplicates alway,

Till roused a Marigold their rivalry,

And caused a split and difference, ne'er to pass, They could not 'split the difference,' alas!

They found a bank and trilled ' We know a bank

Whereon-' their wildest hopes were not deceived, They ran upon the bank, which did not break,

As 'broke' the bank in which I once believed! (The folks who made the ' run' upon my bank

A 'plant' found also-but felt not relieved.)

Below the bank a stream did slowly creep, Some say a foot-some say twelve inches deep. 
Upon its margin found they what they sought

(Beside a prickly cactus maple bush),

One specimen alone, 'twas dearly bought,

Each for the treasure made a sudden rush,

Each for the trophy struggled - nay, they fought!

Alas! each maid the other gave a push.

I tell--I tell the tale as I was told,

Much misery cause did this mere Marigold.

I told-I said did each the other push,

Why e'en the telling's like some fearful dream !

Fell one her full length in the cactus bush,

While fell, alas, the other in the stream!

Then silence fell-till broken was the hush

By two loud screams that merged in one long scream-

I wish myself the tale had ne'er been told,

I hate the very name of Marigold!

She in the cactus bush the first got free,

What pain as out each prickly point she drew!

'Thought she where might her one-time sister be?

No! at the stream not e'en a glance she threw,

Happy, if guilt can make one so, was she,

Her eye triumphant did no tear bedew,

She left-it was not right, but she did hold

In her right hand the long sought Marigold.

The other, doomed a water-nymph to be,

What fate was hers-say, what tho' she could swim?

A Beckwith medallist 'tis true was she,

But river-mud holds with a grip that's grim. 

Botanists beware!

The rare (and fatal)

mongolian Inagnum Marigold.



The Bibliomania



"In the devious labyrinths of "The Lane" Relieves him of his purchase-

and his life !. 
Tho' full twelve inches deep that stream might be,

Mud free from, were her chance of life not slim:

Fixed she till other ' weed disturbers' bold

By chance that way came-for a Marigold.

* * * * * * *

They found the body in the stream so 'clear,'

'Twas strange, they thought, in mud to thus remain, They fished it out and scraped it down with care,

And then they stood the body up to drain.

They asked how came it to be lying there-

What made it fall :- Then said with cold disdain

The owner of the body-'Hers the sin,

I did not fall-my sister pushed me in!'

What of Old China? Listen!

Old China has, alas, seen better days

(Ere China broken up was by Japan).

My Aunt Matilda (What! you aren't the man

To laugh my aunt at!) famed was far and wide

For her rare ware. Her 'pieces' much she prized,

The simple spinster who oft prophesied

(And she believed it, too!) that, when she died, Would they, who took the care to find it, find

Dear Dresden's name engraved upon her heart.

Her crown Crown Derby was (she'd never seen 
The Derby-as for that, tho', what's the odds ?), And Doulton ware she loved, but, save her Sèvres, Naught charmed her as did Dresden's dainty wares.

Much of her china was of Worcester source,

The Chelsea Sage on Chelsea China, sheThe vulgar said she 'Took the Chelsea Bun!'

Majolica (Majorca's mystic make)

Appealed to her, with Willow Pattern, too, E'en Biscuit China (this the biscuit takes!) Did she, with Gold and Silver Lustre Ware, Include in her collection; and, I'm told, No terror Terra-Cotta had for her.

Catholic her taste, she ne'er 'No Pot-pourri!' cried, But, broadly, she collected everything.

Still, it was Dresden she had on her mind

(As on her heart-if what she said were true), And when she sang (don't laugh!) her song would be That sweet refrain 'The little he and she.'

Aunt 'Tilda died-I put it thus, tho' she Was really-but, no matter, say she died! What of her china? It was all 'dispersed,' She left no will, but, still, 'twas all 'dispersed' Amongst her relatives-And I got none!

Let me add, tho', that you your scorn may spare, I was abroad-or I had got my share.

Will you believe it? - No, I see you won't!

But they who took Aunt's china did not take The trouble to call in a specialist, To find if what she'd said about her heart 
Were true or not. They'd reason, p'r'aps, to dread A full post mortem. Know you how she died? She slipped upon the stairs, and, slipping, fell And broke her neck-and p'r'aps her heart, who knows? Her craven nephews and each nervous niece, When losing Aunt, appeared to lose their heads, Else had they found, I'm certain, Dresden's name Engraved (taille douce) upon Aunt 'Tilda's heart. Enough! for I've to mind my own affairs, But I believe that - that they greased the stairs!" 


\section{$\mathrm{X}$.}

\section{Stamp- Fiends Trmo.}

The knight in khaki silent sat

When I had told my tale, He ruminated-so did I-

And not without avail ;

For schemes my busy brain evolved,

'Twas clear, and I felt prime,

How could I turn to good account

My knowledge of The Crime?

I have it-and by George I had!

A simply grand idea.

My brain had never felt so bright,

So beautifully clear.

The "Scotch" had not neglected been,

Had Paul drunk like an ox

While I arranged some little things

Within my "thinking box."

Did Paul regret his confidence?

Regrets were now too late,

I in my hand the giant held,

Was master of his fate. 
I'd yet a famous figure cut

(Stamp-fame was all I sought)

With Paul the central figure in

The Central Criminal Court!

Justice of course demanded that

With her I should not play,

I justice love, tho', nowadays,

Does love of justice pay?

In her stern cause to fight and win

The public's loud applause,

Should I speak out_or silence keep

In Philatelia's Cause?

The die was cast - that is a "bob,"

Unseen by Paul, was tossed,

'Twas tails for Philatelia! and-

Alas! Justitia lost.

Fate stronger proved than my poor will,

We mortals are but worms,

Now with the giant I would make-

I mean,--dictate my terms.

Paul's Stamps, of course, must mine become,

He was no longer fit

With Us, whose hands at least are free

From blood, to "swap" and sit.

No doubt I coveted his Capes

(I'd sell the one accursed),

I coveted, too, something else-

Tho' Stamps, I own, came first. 
Fair Pauline-o'er that peerless one

Would I, to get a hold,

Have bargained e'en with-you know whom,

And would my soul have sold!

She would be forced to say "I will"

When asked to be my wife,

For what else could she say to one

Who'd spared her brother's life?

If I her brother "gave away"

Could I " the question" ask?

And how could Paul give her away?

'Twould fruitless make my task.

No, Pauline's tender ear must e'er

That secret dark escape-

The sanguinary history of

Her brother's Blood-red Cape.

How could I meet fair Pauline's eye,

That eye so sof 5 and true,

If, in a moment rash, I did

What p'r'aps I ought to do?

To take from her a brother dear,

Was he her all in all,

And rob the peerless Pauline just

To "pay" the pirate Paul!

A strange construction would she put

(Here Stamps creep in again)

My action on if, so to speak,

I'd re-construct Paul's pain. 
But they need ne'er divided be

If I and Pauline fair

Became (this wheeze is copyright!)

"An undivided pair."

Still, Justice must be satisfied, The Sherlock Holmes-like net

That I would spread implied that I Myself would justice get.

Between two stern alternatives

Friend Jones would have to choose-

The loss of his collection or

The hangman's shameful noose!

The hand of Pauline, with the Stamps,

I'd spread my net to get,

A high price for my silence, but

The price itself was net.

Without my price I'd ne'er become--

In any form or shape-

A party to a plot to cloak

A murder for a Cape.

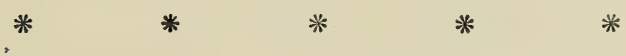

Next moment to his feet leapt Paul,

"Fools to be sitting here!

Up and away-time precious is,

Don't argue, out you clear!" 
I'd fully now resolved to go,

But I would not appear

Too anxious, so I said to Paul,

“'Twill prove my death, I fear.

To drag me out on such a night

Is murder, nothing less."

"That word is barred, and so is Cape-

Put on your Inverness!"

But when I plaintively replied,

"Leave me to rest!" said he.

The while he threw my cloak on, "Come,

And leave the rest to me!

You'd never, lad, forgive yourself

If you to-night should miss

This chance-thro' life no second chance

You'll ever have like this ;

You talk of dying now, but if

To come you don't decide,

You'll later on learn what you've lost-

And then-you'll suicide!"

And now the "Highland" spirit broke

The Influenza's spell;

An hour ago a wreck was I,

And now I felt so well.

Alas! the subtle enemy

Had left me but pro tem.

What penalties I'd soon to pay!

But there-why think of them? 



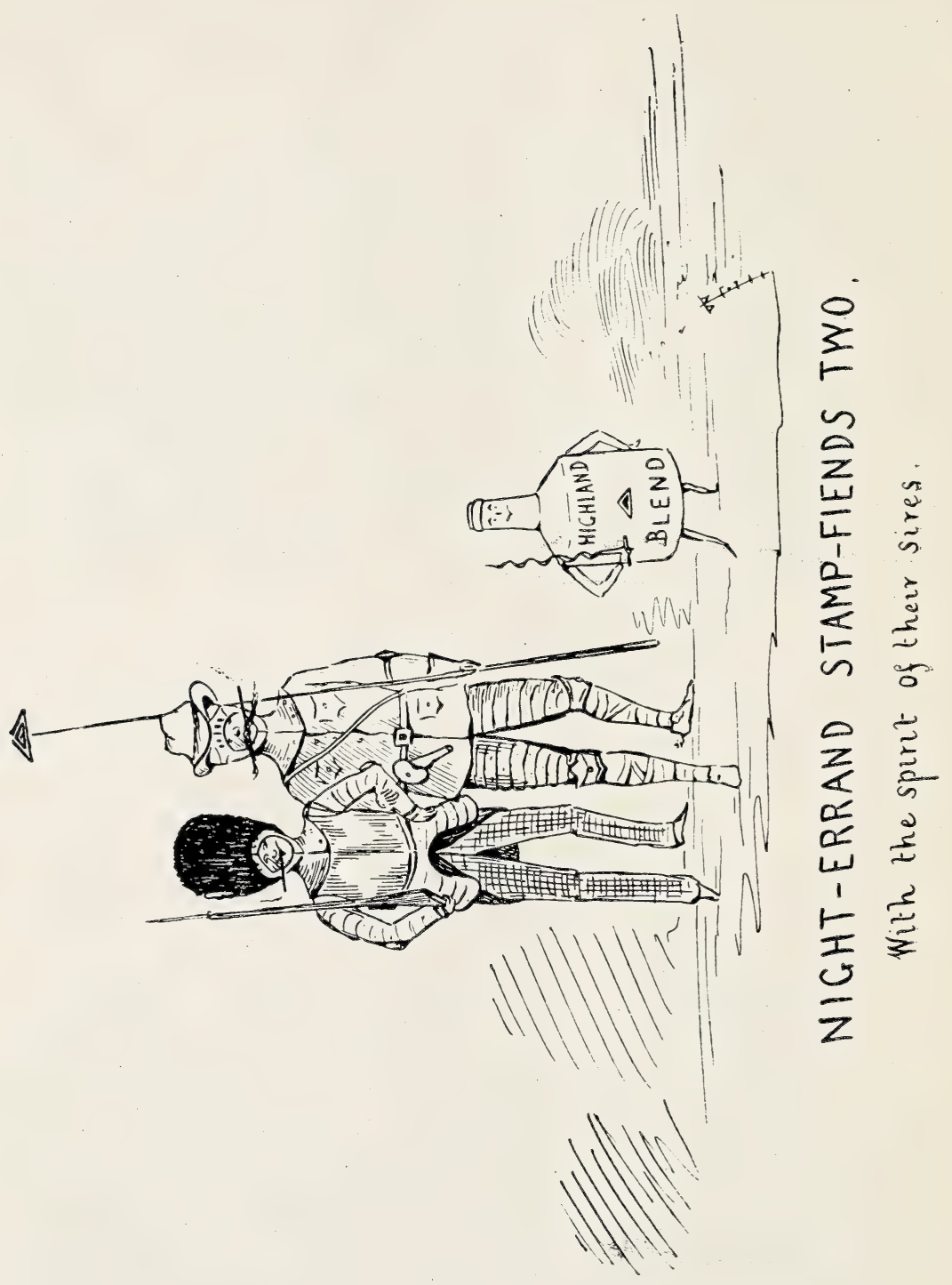


"I'll come with you, yes, come what may!" Said Paul, "Then come at once!

Despite your knowledge vast of Stamps, I'll prove you're but a dunce;

You deem yourself 'advanced,' forsooth, But you advanced shall be

Beyond the most 'advanced' if you This night advance with me!"

He roughly turned my collar up, And then my choler rose.

"You come to take me out, but it's A 'take in' I suppose?"

Said Paul: "You're paradoxical, It's catching, too, no doubt; I've put you in your cloak and now I mean to take you out!

You see, Will, I've come well prepared, For danger lies ahead."

He gripped the sword hilt at his side, And with grim smile he said, "I've come prepared to make a stand, Or else to make a bolt, Not only have I brought my mareI've also brought my 'Colt.'

You too, my lad, must carry arms." "Then you must carry me," Said I, " for I can't carry much " "Excepting "Scotch,", said he. 
“Your new six-shooter don't forget, Now do, lad, as you're bid!"

I swore I wouldn't take it, butThank heaven that I did!

"And now your full regimentals don." (How "Scotch" affects Paul's head!) "The part you play well dressed must be." " Not dressed like that," I said.

"The khaki fever rages and,

Ere we our fortunes try, I'll see you first your war-garb don."

"I'll see you first!" said I.

"Fine feathers make fine birds, but if A night-bird I'm to be,

Dark cloak and slouch hat suits the partIt's one of villainy.

I know you well! "- “ Tut, tut," said Paul, "Black, red, or blue or white

Your choice make - so you make your choice To come with me to-night!

But wear your sword at least, my buck."

"I'll wear, Sir, no such thing,

It's just for show-as well you know, And I'll no ' snap-blade' bring. My sword-cane from Toledo came, And, you can take my word, I'll trust my life to that-but not A regulation sword." 
“Well, you don't ' come from Sheffield,' tho' Your 'cut's' as sharp as steel,

I've had good cause to see the pointWhat's more the point to feel; Out at the front you'd often hear The regulation damn

For regulation swords that snap, And cartridges that jam.

But Bess will make a bolt if we're Not down in half a tick, She's getting tired of waiting, hark!" "By Jove, Paul, can't she kick!"

"Come on-to-night will you enlarge Your Philatelic view, For Stamps we'll go a hunting in Fresh fields and pastures new." 


\section{XI.}

\section{Pennp-Black Bess.}

Paul's private hansom stood without, But one quite new to me, And that black mare that pawed the air

I ne'er before did see.

The driver looked a heavy swell-

Like most who "privates" drive,

He wore a special badge with a

Plate-number-" Two-two-five."

When off we dashed, the mare's pace put

A motor-car's to shame,

I, just to keep my pluck up, kept

Repeating "It's a dream!"

'Tis strange how things in dreams seem real,

Yet, when we're wide awake,

'Tis stranger still that what's quite real

For dreams we oft mistake.

"Where did you pick that mare up, Paul ?

She looks all legs and joints."

"You're right, my boy, Bess is indeed

A mare with many 'points.' 
I picked her from a wholesale lot Of remounts for The BluesThe only sound one in the crowd, So how could I refuse?

Bess is my second charger now, I hunt the mare as well,

In harness she's all right, and in "The Row she looks a swell."

"Bess earns her bit o' corn," said I, "On general work she thrives,

I wonder you don't also make Her clean the boots and knives!"

“' I call her 'Penny-Black' tho' she Was simply christened Bess, But that prefix a sound has Philatelic more or less.

Maybe Black Bess sounds strong enough, And shorter, too, to state, But she's a mare that well can bear An extra Penny-weight.

Her Philatelic pedigree

You will, I think, admire, Her dam was Damoselle O.G., Face Value was her sire.

For Stamps she's quite a passion got, Her stamps, too, none can beat, When in her ear you whisper 'Stamps' She snorts and stamps her feet. 
In Stamp-Fiends' Two-Year Selling Plate The 'books' were fairly ' sold,'

Bess, as a two-year-old, romped home (Tho' scarcely ten years old).

She started, lad, at 10 to 1 , And won at 1.15 -

The quickest run on record."

Had Paul so "mixed" ne'er seen.)

"She runs at Phils' Park, Monday next,

Who backs her won't repine, She'll beat them all-nor do I bar

Bas Bleu (without-the-line).

Our 'boys' are 'putting on their shirts'

(Paul's slang the biscuit takes!),

The whole Brigade swears Bess 'll win

The Philatelic Stakes.

She's fresh as paint at night, but takes,

In day-time, forty winks,

She'd sleep then thro' a bugle-call-

Unless a call for drinks.

Bess always kicks at day-work, but

For night-work's fresh, of course,

I tell you, Will, that mare of mine's

A night-mare kind of horse."

Said I, “ A mare, with points so rare,

Might well refuse to run

When harnessed to a common cab."

Said Paul, "You're poking fun. 



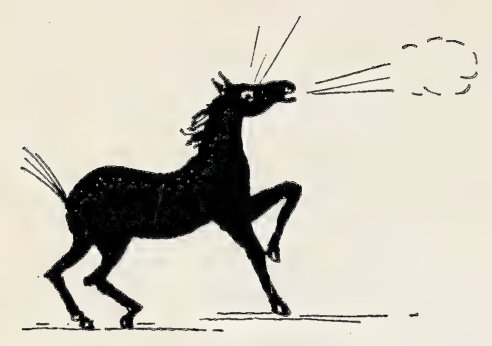

In the "Stamp" mood.

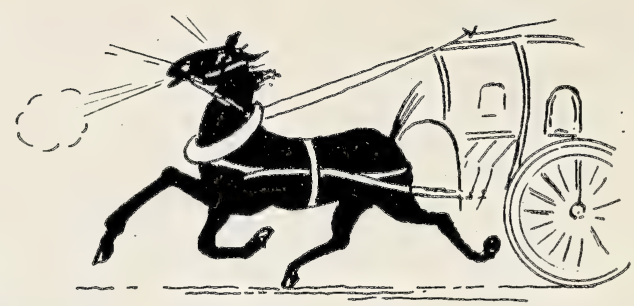

In the hansom.




A most uncommon cab is this,

To draw it Bess is proud;

She'd draw no shabby hansom, for

She's far above the crowd.

See-Call you this a common cab?"

And Paul a button pressed.

Lo! flooded with electric light

The cab was. I confessed

My error (" errors" greater still

Were in that bright light seen) :

The queen of handsome hansoms was

Paul's cab-“"The Hansom Queen."

Its roof was neatly covered o'er

(The sight nigh struck me dumb)

With Twopennies Blue without-the-lines

(Without, of course, the gum).

And shocked indeed was I to see

Our Science thus abused-

So many unused rarities

For such a purpose used.

The sides and back were papered with

(Paul has more cash than sense!)

Whole "panes" of unused Pennies-Red-

What gross extravagance!

And, not content with common stamps-

To outdo all he strives-

The lavish Paul must needs employ

Mint "panes" of Two-two-fives! 
Think of it, reader! 'I for years

To re-construct a "pane"

Of this plate-number, Two-two-five,

Had tried, and tried in vain ;

Tho' near my goal, for my sheet was

But seven "letters" short-

If short my "pane," my pain was long-

(A re-constructed thought!)

Who starts out to re-form a sheet

His language need reform,

Lest he at each long standing " blank"

In language blank should storm.

The missing stamps, as nears the end,

To capture are the worst,

Somehow you never seem to get

The last few wanted, first.

* $\quad * \quad * \quad * \quad *$

Paul seemed, just then, to be asleep,

So now, thought I, I'll play

The (pirate) prince, but I will let

The sleeping "beauty" lie.

That "beauty's" waste of Two-two-fives

All decent Phils would slate,

I'd like, indeed, to " have on toast"

This "bloater" of the "plate." 
My knife-my penknife-happy thought !

(If disappointed here,

There's lots of killing later on,

So, reader, persevere!)

I'd cut them out-were Paul awake

I had been spared the task,

For he'd have offered naught, and I

Had been too proud to ask.

Too proud to ask a favour, which

I knew had been refused,

Too proud Paul's generosity

Thereby to have abused.

But Stamps, to such base uses put,

Temptations prove to all,

They'd fit my "blanks" far better than

Mere paper on the wall.

Were Paul and I, before aught else,

Stamp-Fiends, as fierce as keen,

For e'en before our friendship came

Our duty to our Queen.

We served each other many tricks,

But our Stamp-hunter's thirst

Led neither to forget that he

Served Philatelia first.

Then no defence I need, for I

Indeed received a call,

And made a great " discovery"

To benefit Us all. 
For, whilst these " plates" I scrutinised, One Stamp my eye did fix,

I trembled-for I'd found a new

Plate-number-Two-two-six!

The last Stamp in the bottom row,

You'll just remember, please,

Look thro' your Pennies-Red and see

If you've got one of these!

My " find" would place Stamp-chroniclers

In a most awkward fix,

They all stop short at Two-two-five,

Nor mention Two-two-six.

My name was made--did Paul know this?

I'd him, at least, forestall,

Morley and Ewen, Nissen, Hilckes-

I'd make them all look small!

Around the finding of this "find"

I'd much romance entwine,

The added glory of " descriptive

Writing" should be mine.

Here for a mystery-monger was

A chance, and rare indeed,

To write a " shilling shocker" which

Millions untold would read:

My "thriller" should from Fergus Hume's

The fame and lustre grab,

My " History of The Mystery of

A Philatelic Cab." 
My friend all claim had forfeited

To such an "error" rare,

He'd overlooked, or kept it dark,

But I resolved to share

My strange "discovery" with all,

I'd live no selfish life,

Then round the perfs. of that rare " find"

I deftly worked my knife.

My task was nigh accomplished, when

(This caused me nigh to yell)

Rang out a clear and loud alarm-

From an electric bell.

Seized with a terror strange was I,

Who could my terror blame?

I leaned me back, then heard Paul's voice"Now what's your little game?"

I stammered " Nothing!" Paul replied, "I hope you'll touch it then!"

He's just about the coolest, most

Suspicious, too, of men.

Jones added, "Don't apologise,

I'm not surprised, I'll own,

It's only non-collectors whom

I trust in here alone!"

But $\mathrm{O}$, what degradation to

Be placed in such a plight!

And what humiliation for

A self-respecting wight! 
Then came this thought-the Stamp-World would Give me well-earned applause,

Something attempted, nothing doneBut still-I'd served The Cause.

Worse was to follow-Bess stopped short

When rang the bell's alarm,

And thro' the peep-hole, cabby asked,

" The usual, Paul, no harm

I hope?" and Paul said, "Drive away!

It's just the usual fun."

Then cabby chuckled, "Every time

You bowl out every one!"

"Who's that?" I stiffly asked. "You seem On most familiar terms."

Said Paul, “O, that's 'The Baron' (I,

Of course, don't mean De Worms!)

His story-if you'd care to hear-

Relate for you I could."

And, glad of the diversion, I

Said, "Paul, I wish you would." 


\section{XII.}

\section{V.R. Menny-Black.}

"A smart Stamp-auctioneer was he,

Who into trouble got,

For putting up a seventh time

A sixth-time bought in 'lot.'

'The Baron' nickname's his, I think

(You may have heard the tale),

Because he sailed too near the wind,

And had a barren sale.

His name is Percy Pennyweight,

The name's a Penny sound,

When he went 'broke' he only paid

A penny in the pound.

The only penny now he's got's

The penny to his name,

And that no longer carries weight-

Altho' his name's the same.

Now what broke Percy Pennyweight

I'll tell you in a trice,

He brake a law unwritten which

No auctioneer breaks twice. 
His first offence forgiven was,

Forgotten nigh, but he

When tripping for the second time,

Went $b-r-0-k-e$.

This second grave" offence was when

His 'Twenty thousandth sale'

Of English rarities was held

(You must have heard the tale !).

For he, amongst those ' rarities,'

To put up quite forgot

The usual V.R. Penny-Black-

That never-absent ' lot.'

It drove his clients nearly wild, And that nigh drove him mad,

It drove him from the rostrum and

To drink it drove him bad;

Drink drove him soon from bad to worse,

Who once was quite a dab

At driving bidders hard to bid,

And now-he drives a cab!

Talking of V.R. Penny-Black-

(I don't refer to Bess)

How is it that the V.R.'s don't

Grow beautifully less?" 
Here a conundrum was, and who

Could its solution know?

"Whence come the V.R. Pennies-Black-

That never-ceasing flow?"

“Ask me another!" I replied, And Paul complied so far,

"Now whence the source of that Black stream?" Said I, "Well, there you are!"

"I know!" said Paul-'twould seem a bolt Had pierced the cab's confines,

A bolt shot from the blue above(The blue without-the-lines).

Paul knew! In mute astonishment, With wildest hopes and fears,

I heard his words-conld he reveal

The secret kept for years?

Which secret, as a secret 'gainst

Who Junius was I'd back,

Who was the lucky wight that held

The V.R. Penny-Black?

"Listen! (From Paul that word had now

A very ominous sound.)

A million V.R.'s once were 'lost,' And never, never found;

The Somerset House officials were

The 'leakage' sworn to keep

A secret-some of them are dead, The others fast asleep. 
Was thro' a junior office-boy

This slight deficit known,

One night on overtime he stayed

To take stock ' on his own.'

He told an outside messenger,

Who mentioned to the 'boss'

The matter, and the latter wrote

The Stamps off as a 'loss.'

But, strange to say, the matter there

Was not allowed to rest,

For Heaton put in Parliament

A question-as a 'test.'

The Opposition's plea for an

Enquiry was opposed,

A Royal Commission sat, of course,

But then the doors were closed.

It leaked out (thro' a crevice in

The R.C.'s chamber-wall)

That, years ago, at Som'set House

A stranger slim did call;

$\mathrm{He}$ in the strong-room wandered, but,

Much to the clerks' surprise,

When out he came did he appear

A man of bulky size!

He said, when asked his business, 'I'm

Connected with the Church.'

Of course they couldn't search him, for

He'd come to make a ' search.' 



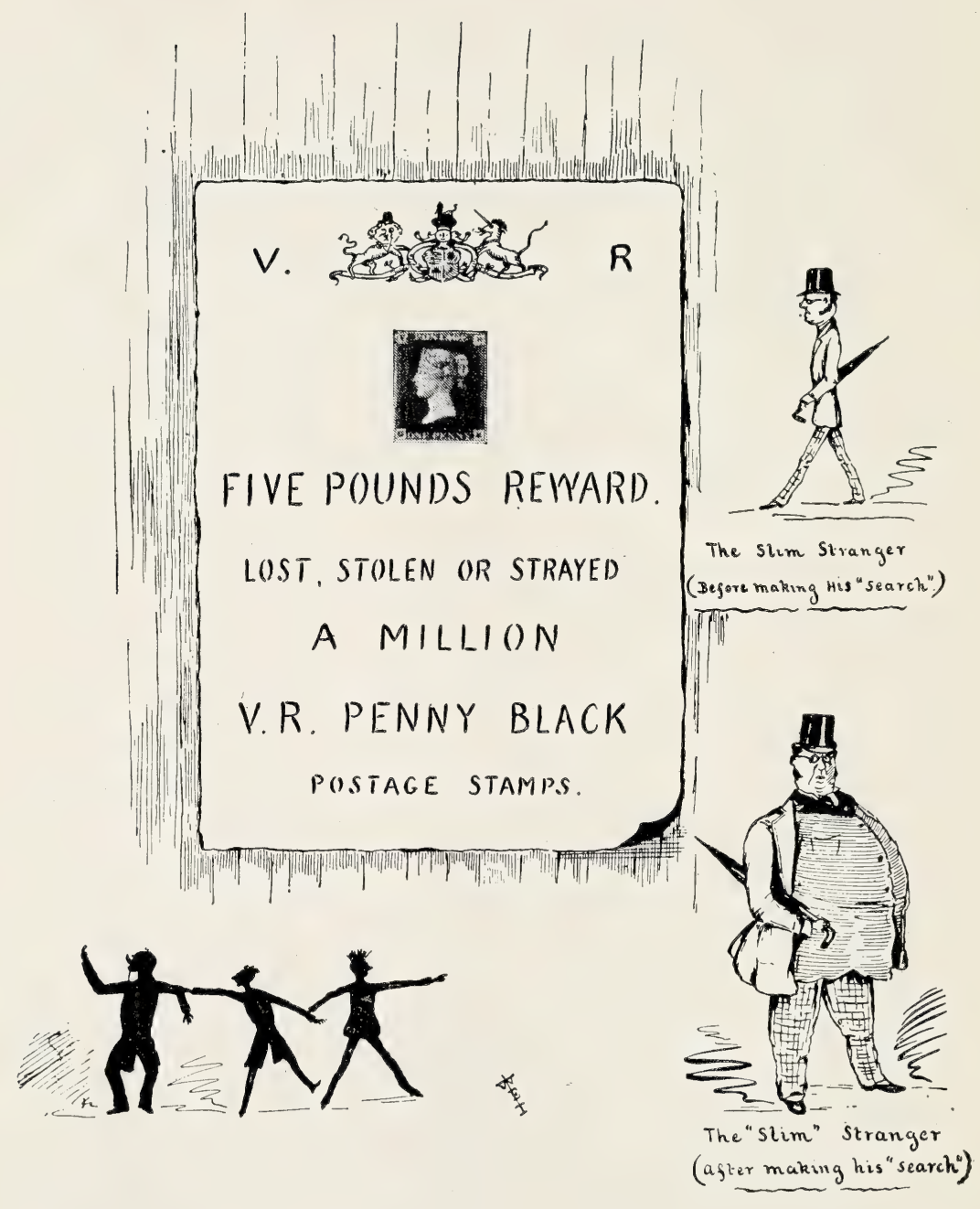


But when he'd gone were things made warm, And half the staff ' retired.'

A 'big gun' came and like a shot The other half he 'fired.'

The bulky man is slim once more (I always thought him 'slim ');

Of V.R.'s they will print no more-But that won't trouble him!

Now, re that Stamp, I'm quite convinced (You'll own I'm not far wrong) That, at the rate he deals 'em out, The million won't last long.

We meet him at the auctions." "Then

Why don't you point him out?

I'd like to know the "slim ' 'un, Paul."

Paul dryly said, "No doubt!

He knows I know him, but he knows

I don't go telling tales.

Tho' keen on Capes he never bids

Against me at the Sales!"

"His name! his name!" with trembling voice, Was all that I could gasp ;

The Stamp-World's greatest secret now Seemed well within my grasp.

But-curse Paul's methods! - - he replied,

"Suppose we change the text?

We've many chats, and this can be

Continued in our next!" 
One little touch of confidence

(The philistine may grin)

Makes serious collectors in

The "wide" Stamp-World akin ;

That secret to relieve Paul of

His hand I warmly pressed,

I called him " chum " and " dear old boy,"

"My oldest pal and best."

"Throw light on this Black subject, Paul !

The V.R. Penny's past-

The truth reveal to one safe Phil!"

Paul acquiesced at last.

"I will not speak, but write his name."

And write it down he did.

I read, then cried, "Don't play the goat!"

But Paul said, "That's no kid!"

One honoured in the Stamp-World was

The well-known name I read,

I can't divulge it, and you'd not

Believe me if I did.

Paul swore that it was true, and I

Believe his statement must,

But when I read the name I groaned

"Alas! whom can we trust?"

"The man's a mere civilian, Will, In fact I'm half afraid

That he has been-or some of his

Folks may have been-in trade 
Of course collectors vary much,

Some are a shady lot,

Tho' you've ne'er met an army man

Who wasn't quite what's what."

"I've met," said I, " no Phil I'd trust

Amongst your army ' cards,'

Not any man in any corps-

And least of all The Guards."

Paul's covert sneer, "The Navy's square?"

Aimed at my brother Fred-

The Scorpion's " first "-who'd hang for Stamps-

It made me hang my head.

“ The V.R.'s ' found' by Mr.-Blank,

We two, I think, might share,

I'll draw up an agreement, for

I've the materials here.

We might make something out of Blank."

"Not might," said I, " we will!"

Paul toyed with pen and paper, tho',

As if uncertain still.

"Now draw it up and sharp!" said I.

Said Paul, "Now draw it mild!"

But I was firm and he obeyed

As might a well-trained child.

Impulsive like I wished at once-

Tho' Paul my wish opposed-

To get it Stamped at Som'set House,

But Jones said, "They'll be closed." 
No matter, on the right side I,

"A mere civilian," stood;

Might Paul have cause to fear me yet-

In fact I vowed he should.

His second secret now I held

(My second scheme I nursed),

This would - or ought to-fetch as big

A price as might the first.

I glanced at Paul, 'twould seem once more

The giant was asleep,

Then thro' my active, sleepless brain

Dark thoughts commenced to creep.

I might have killed him then, and off

With that cab's treasures made,

But killing's no civilian's work-

And each man to his trade.

Asleep ! - who'd e'er catch Paul asleep ?

He'd been but thinking hard,

"I'm thinking what I told you, Will,

Requires your solemn word

That you will ne'er divulge it, and,

To make it safe for both,

I'll take you at your word, but you

Will have to take your oath!

You sometimes write Stamp-articles,

But, what I've told to you,

If you make 'copy' of, you'll cop

It-sure as I'm a 'Blue!' 
Now, Wylie, swear!"- then I commenced, But Paul said, "Gently there!

I swear that here you shall not swear The usual oaths you swear!

The Stamp-mags. mustn't squeeze from you The facts I've brought to light,

A firebrand such as you might well Each magazine ignite;

Just fancy the explosion then, Were you to drop the spark, And let in sudden daylight on

What I've kept in the dark!" 


\section{XITI.}

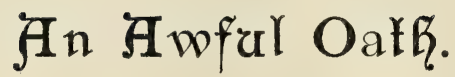

Paul bound me by an awful oath

To be for ever dumb

About the V.R. scandal (which,

No doubt, is very rum).

The other secret, darker still,

Tho' far more red than black,

Did Paul include the oath in

That he made me take, alack!

The oath included all that Paul

Imparted had that night,

The cruel Cape crime it covered, and

The Fur-Coat secret, quite.

Apart from keeping secrecy,

The oath also implied

That, come what might, our mission we'd

Accomplish-tho' we died!

"You'll have to take an all-round oath

To act square by a flat-

For you've got round me in a way.

Which proves that I am that! 
Swear by collectors, dealers, and

Collector-dealers, too,

The list's indeed a long one, so

You'll have to help me thro.',

To swear, I had to follow Paul,

The swearer, word by word,

To.swear by this, and swear by that-

Such swears you never heard;

Without a doubt a novel swear,

Instructive, too, to both,

It was indeed most ì propos-

A philatelic oath.

"First by the journals you shall swear,

For journalists, I've found,

Consider few oaths binding, tho'

To swear by books they're bound.

To-night, maybe, you'll make a book,

It's long odds that you may,

And then I'll swear by that, if you

Don't give the show away.

You'll swear by Morley's Journal, for

It's one by which I swear,

The Philatelic Journal of

Great Britain comes in there!

The P.J.I.- the A.J.P.,

(Both A.J.P.'s., I say!)

By Mekeel's Stamp News, which they swear

By in the U.S.A. 
The Stamp-Collectors' Fortnightly,

You'll find there, if you seek,

Of ' copy' much to make you wish

It came out once a week ;

By Ewen's Weekly News (tho' I

Find nothing weakly there),

The Monthly Journal-don't I wish

That, too, a weekly were!

By The London Philatelist,

Whose matter's up to date,

Else for its monthly coming out

Say-why should London wait?

I swear you by The Connoisseur

(With Sale Prices so useful),

Now swear by The Exchange and Mart!

(I swear it's of Stamp-news full).

'Now swear by Stamps-if Stamps be dropped, Then swear by Stamps alone,

The Philatelic Record, too-

Swear by E. J. N.'s own!

The Stamp Collector should include

A Stamp-collector's oath,

We're Stamp-collectors, too, and so

You'd better swear by both.

The Burlington you'll swear by ; it

Might well be christened. 'The

Burlington Arcadia Mixture'

(That's not bad for me). 



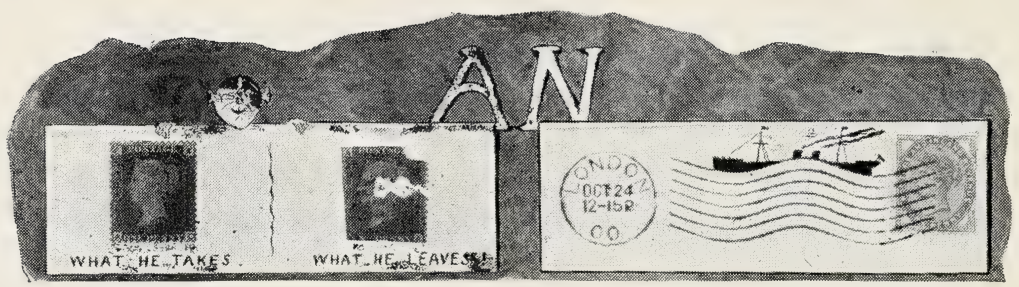

The Substituting Fiend.

The good ship Cancellation.

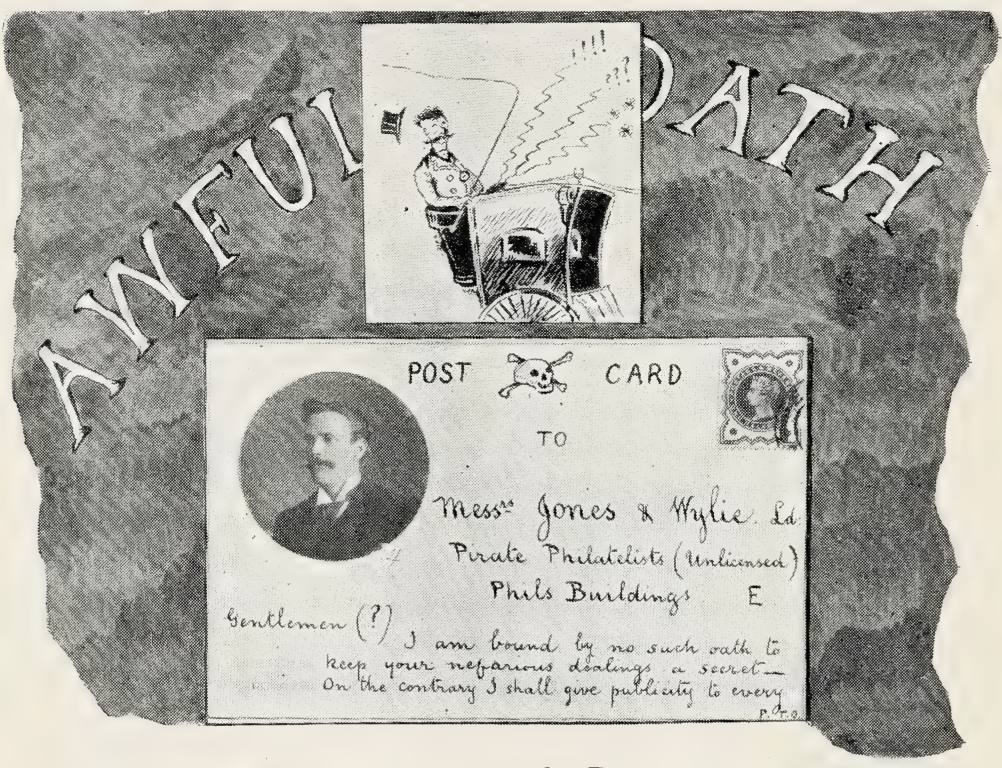

"Picture" Post-Card (The Perpetrator's). 
But there-I can't swear you by all

The mags., 'twould take too long;

The few I've named, tho', ought to make

A binding oath and strong.

Swear by the Picture Postcard, too,

We oft at postcards swear,

But never at such dainty cards

As one finds pictured there.

By Hobbies swear! (as each one swears

His hobby by, and pet,

Tho' yours and mine has been the cause

Of the most swears as yet).

Now as you've sworn by postcards, you

Must Postmarks give their due,

Of course they're both 'side issues,' tho'

A postmark's not a 'view.'

Why snub who in for postmarks go?

The faithful steadfast few,

Why stamp obliteration's mark

On Cancellation's crew?

The Cancellation steams ahead,

The ship requires no 'sales,'

Curtis and 'Duplex' stick up for

The non-adhesive males.

Each dares to be a Daniels, and,

To form an 'entire' crew,

The Warden of the Postmark-Ports

The ship will pilot thro'. 
Now by the big Collectors swear!

This means a great big oath-

But that's too long and would too much

The time take up of both;

I'll only name the names of such

As would not cause to die

A 'Cape boy' for a woodblock Cape"-

" That won't take long!" said I.

Paul mentioned three, "But then," said he,

"Two of the three I doubt,

Whilst as regards the third one-well,

I've not yet found him out!

He was not once quite dead (to shame)

(Paul's ambiguity

Is grand), but now he may have joined The great majority!

Swear by the Phils who 'on the cross'

Their little deals arrange,

Swear by the 'substituting' fiend

Whose robbery's no 'exchange.'

Swear by the 'straight' - the Stamp-World's saints,

Who ne'er from virtue fall!"

("Does that include the present saint-

That precious saint-'Saint Paul'?")

By every Postage-Stamp that's priced

(Subject to rise or fall),

By Stamps o'erpriced and underpriced,

By Stamps not priced at all, 
By Stamps depreciated, and

'Inflated' Stamps as well,

By Stamps that you can never buy-

And yet can never sell!

Now swear, sir, by the dealers, whom

We all regard as foes,

We all can do without them, but-

We don't-why-goodness knows!

Their name is legion, tho' we call

Them far worse names than that,

And now do I intend, you dog,

To swear you by each eat!

Swear by the King-our Whitfield King,

By able Lincoln swear!

By canny Scott, and swear, Great Scot!

By Bright and Senf, nor spare

Your swears, but swear by one and all, And now-you'll kiss the book!"

Paul swore me on a Gibbons and

The awful oath I took! 


\section{XIV.}

\section{Eaștwand Ho!}

Now what, think you, this made me think?

(I can't, whilst Paul's tongue wags !)

That, come what might, Paul's secrets were

Fair " copy" for the mags.

The L.P. or the M.J. might

Accept Paul's V.R. " rhyme,"

And p'r'aps the sprightly S.C.F.

Would print the cruel Cape crime.

The Cape-Crime's not a story, p'r'aps,

A bishop ought to see,

But still, I know one Bishop who

Might take it straight from me :

I think he'd keep his hair on (tho'

The story bald may be),

I would't trust all bishops, but

This Bishop's Percy C.

'Twixt duty, Stamps, and friendship must

I choose-now hear the worst !

Philately took second place,

And journalism first. 
Why waste good " copy"? — oath or not,

I use no canting plea,

For "journalistic enterprise" .

Is good enough for me.

I'd fix my price, "ten 'bob' a line,"

And spin the story out,

Like other men, I've got my price

(So's every man) ; I'd scout

All offers at the usual price,

This time they'd have to pay,

I'd make an extra special tune

Some special " organ " play!

The Stamp mags. ought to form a big

Combine to buy me out,

If not, I'd try the fountain-head-

And "pull it off," no doubt.

Then Paul must suffer for the Cause

(He ought to for his "rhymes!")

No secrets would I keep if I

Could sell them to The Times.

* $\quad * \quad * \quad * \quad * \quad *$

Black Bess's pace had put to shame

Her namesake's run to York,

A run which, if compared to ours, True sports would call " a wall." 
"The Borough-and already?-well, Bess isn't-but I'm blowed!

Why, one would think The Burrow House

Was near the Borough Road!"

Then dear old (dirty) London Bridge

We crossed as in a flash,

We bumped King William's statue, for

Our pace was mad and rash ;

Upset a sleeping " bobby," whom

To Fenchurch-street we hurled,

"And now," said Paul, "we cross the line, Into the wild East world."

Said he, when we passed Aldgate Pump,

"Down there's our final pitch."

With horror I exclaimed, "You hound,

To bring me to Houndsditch!

From Wimbledon's fair common far,

These common slums to view,

You've dragged me-and you say that these

Are 'fields and pastures new' !"

“ Now, Percy, drive for all you're worth

(I know it isn't much!),

You'll touch me for a 'fiver' if

A record pace you touch.

We're overdue now at the pub,

You know the house I mean,

Give Bess her head, for we must reach

The Boar's Head, Bethnal Green! 
That house we'll famous make to-night,

The ' wild boars' muster strong

(A thirsty set of hogs' heads they)

For drink and dance and song;

They and their chief, Bill Bludgeon, called

'The Boer,' I entertain,

A worthy use for worthless men

Has found my fertile brain.

The famous 'Fighting Forty' whom

No fear of numbers daunts,

Who've sworn they'll ne'er be crowded out

From their own native haunts.

If you'd win Bill, as I've won Bill,

Whose friendship's quickly made,

Roundly abuse all foreigners,

And freely curse Free-trade!

Bill had a nephew at the front,

Who sent him War-Stamps weird, And war-news, too, the like of which

Has nowhere else appeared.

Still, in his own set, Bill's a sage,

And you must let him jaw,

Don't drag in Stamps until he's had

His say upon the war!

Then, chummy, there's where you come in,

('Else why should I come out?')

Bill's War-Stamps are unique and you

Can quite 'clear out' the 'scout,' 
See that his glass to-night's well primed, Four ale is very cheap.

Your War-Stamps. Bah! - when you've seen Bill's You'll say you've been asleep!"

"He'll show no Stamp that I can't showNo War-Stamp, Paul, I'll bet!

My specialised collection's quite Complete-I've the full set.

But still I'd like to hear ___" and then

I heard a "bursting" sound.

Cried Paul, "Please stop, or you'll have me Soon rolling on the ground!"

"Go on," said I. "O lor!" gasped he.

"Do stop, for pity's sake!

Your calm assurance takes the bun-

It does-it takes the cake!

Your 'specialised collection' -why

You'll see War-Stamps, forsooth, That you'd not even dream about!"

Now, did Paul speak the truth?

"But here we are, now out you get, Bess hasn't turned a hair,

Percy, my boy, the 'fiver's' yours

(Paul was an ideal fare).

Now to Phils'-buildings drive; tell Ben

To-night no bids he'll lack!

Refresh yourself, and don't forget

To water Penny-Black." 



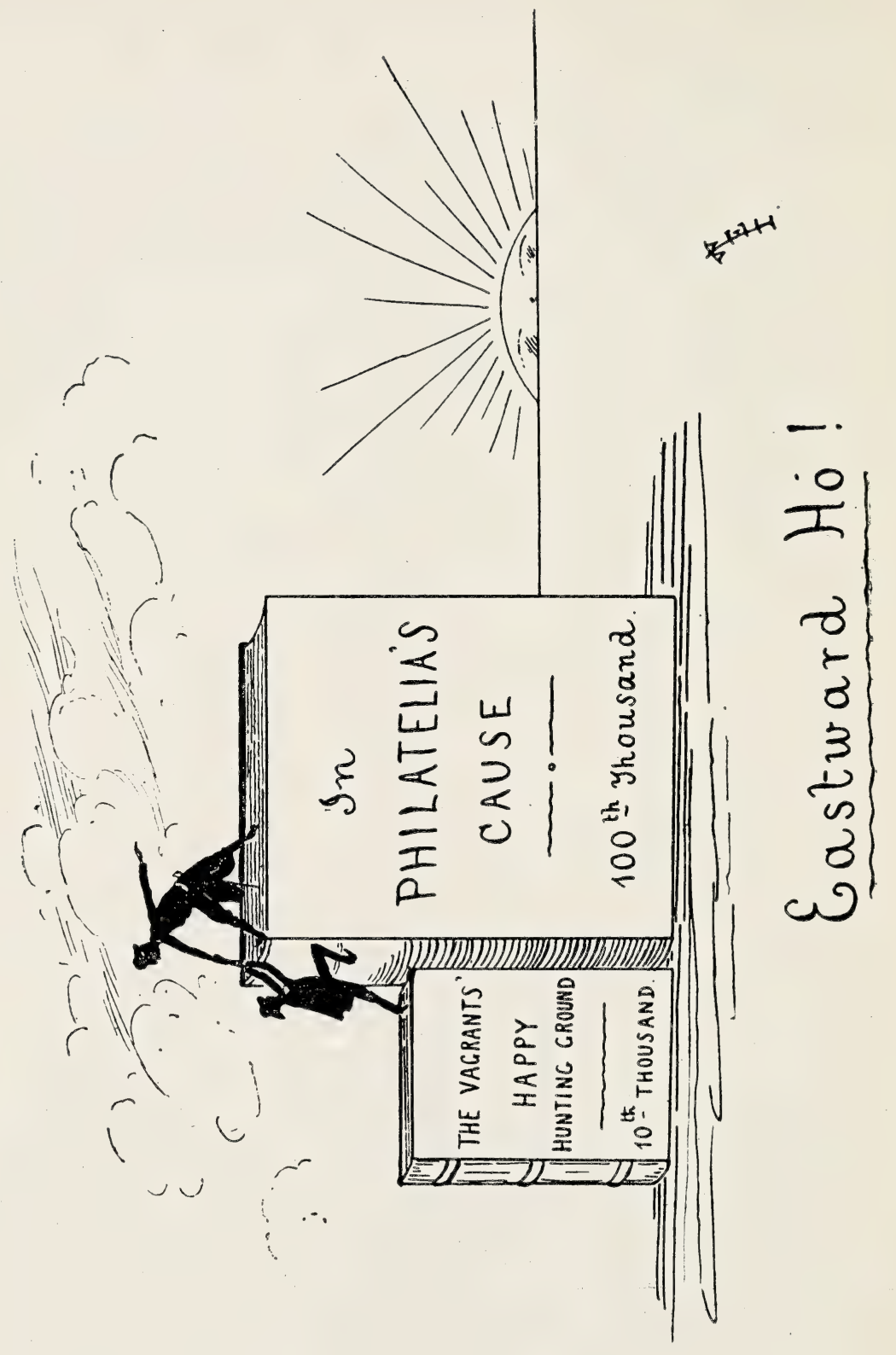


A quaint old house, The Boar's Head pub, At which we did alight,

"A philatelic concert, Will, You're going to hear to-night; All this and more I'm doing inIn what?"-Paul made a pause, Then I whipped in and answered, "InA certain lady's Cause!"

“ On all that we go thro' to-night If you some notes, Will, took, You'd subject matter have enough To make a thrilling book;

One that in startling incidents, (And lies, too, I'll be bound!) Would hollow beat and far eclipse Your 'Vagrants' Hunting Ground.'

Now, mark me, Will! - but you must write As you ne'er wrote before.

The book by millions ought to sell-

For real Stamp-murders score.

The Stamp-World, and the other worlds, Will copies all require,

For, so to speak, you'll set the Philatelic Thames on fire!" 


\section{XV.}

\section{The Boen o' Bethnal Grqeen.}

Then entered we "The Boar's Head" bar. Said Paul, "Come on, lad, here we are!" And here we were a rag and tag Amongst - all smoking pungent shag At which could but the strongest pullThe Boar's Head " Negro Head's" so full. Bill's special pals were gathered hereChoice spirits all, imbibing beer From pewter pots, which in their day Had played a part in many a fray, For dented rim and battered spout Much "filling up " and "falling out" Most eloquently spoke about. Our entry was the signal for A shout of welcome from a score Of thirsty throats. Paul shook the hand Of each one of the beery band, And stooped to conquer in the way He knows so well and well makes pay. I was presented as a "brick" And one who would at nothing stickOne of the boys who'd win his spurs In helping oust the "foreigners." 
The Captain glanced around the den.

"Where's Bill?" In chorus cried the men,

"'E ain't cum yut; Bill's riggin' 'igh,

An' gittin' ov 'isself up spry."

"Dressing the part?" said Paul. "That's well-

I like a fighter who's a swell."

Said one, "'E'll wake up this caboose ;

I seed Bill toggin' werry spruce."

Paul had all pots replenished first

("To fire their ardour, quench their thirst,"

He whispered), then proposed a toast:

"Phil Philpot, lads-our worthy host!"

As Pnil, as fill-pot, took his post.

And then Paul spoke-might well appal

His craft_-'twas diabolical.

"Friends," he commenced, "we're here to-night

If need be in the cause to fight

Of freedom and of liberty,

Of justice and equality.

We'll see no more that such as you

Are ousted by the German Jew,

Nor trodden on by 'Parlez-vous'

(They're neither of them worth a sou),

Nor plundered by the Portuguese,

Who, while you labour, live at ease

In luxury - the Italian, too,

Who grinds the organs made by you,

Whose ice-creams, made by his foul hand,

Your kids send to the better land.

к 2 
For you we'll win-I do not bragA fairer share of beer and shag."

And whilst they cheered the latter part

Paul asked me, "How's that for a start?

I've primed 'The Boer' who well has primed

These vagabonds - the fuse is timed, And an explosion vast and grand Takes place to-night-you understand ?"

Said I, "Not quite; it seems to me Out of your depth you soon will be!" "It's sink or swim, Will-even soAnd I'm not one to drown, you know.' "But I'll be hanged if I can see The drift of the conspiracy!"

"Conspiracy be hanged!" said Paul.

"Whom do we fight for, after all ?" To argue now I would not fag, But I'd anticipate his "gag." By heart I knew the saving clause"We fight in Philatelia's Cause."

Just then a one-eyed man looked in. “' 'Ere's Bill," he chuckled, with a grin.

“' 'E's faked th' fittins just a treat. S'welp me bob, 'e do look neat!" An instant later in there came The demagogue of local fame.

'Twas "Free cheers, boys!" when Bill was seen. " 'Urrar ! -Th' Boar o' Bef'nal Green!" I'd here a brief description give Of one whose name and deeds will live 
In Philatelia's annals when

She lists her faithful serving-men.

Above the middle height was Bill, About the middle weight, but still The sort of middle-weight, no doubt, That oft a heavy-weight knocks out. A face "clean shaven" his was, save That he'd not had a recent shave; Round chin and lip a stubbly growth Showed several days' neglect of both. His eyes, if beery, did not lack Expression; one, just then, was blackA mark of honour for the "Boer" As senior "wrangler" on the war; The bull-dog type of firm-set jaw (For strong ale fit or spirits raw) A type of man, confess I must, For standing to his guns, I'd trust.

Bill's turn-out was both queer and quaint, For he showed up in full war-paint. His vest, symbolic of true pluck, Was made out of a Union Jack.

A sort of market-porter's coat He wore. The "choker" round his throat A " necker" was of brilliant hueAn Easter Monday shade of blue. Trousers of corduroy had he; Brown-paper leggings reached the knee. 
On his shock-headed head he wore A tall, soft felt hat-ì la Boer. Completed his equipment gay

A stout oak stick and short, "strong" clay.

Paul's intro' was a pretty scene,

“'Will, here's 'The Boer o' Bethnal Green.'

Bill, fix your optics now upon

My pal, 'Wild Will o' Wimbledon,'

Who, all the way from that wild land,

Has come to shake your honest hand."

Next instant was my hand compressed

Within Bill Bludgeon's " honest" fist

With grip the thought of which recalls-

Tho' hardly such a grip as-Paul's.

Said my new friend the Cockney "Boer,"

"I'm werry prahd an' pleased, I'm shoar."

Then, in stage-whisper, Paul did say,

"You've caught on, Will. Now lead your prey

To yon quiet corner; there remain

Whilst I the 'boys' here entertain."

* * * * * * * *

\section{(Ad Interim.)}

Now in "The Boar's Head" pub you might,

Had you been there, have seen

"Wild Will o' Wimbledon" beside

“"The Boer o' Bethnal Green." 





可约屋圆(1)展

(i) ${ }^{2}$

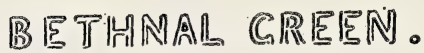


The former did the steering while

The latter plied the oar.

Bill asked, “Nah, wot's th' latis' noose

Yer've 'eeard abaht th' woar?"

Said Will: “The latest news I miss-

I'm such an early bird."

Bill Bludgeon said, "Yer lis'en then,

An' 'ear th' noose I've 'eeard!

I ax ver pard'n-I fergut

As yer cum, ter be shoar,

From Wimble'un, an' p'r'aps aint 'eeard

As 'ah ther's bin a woar!

Yer ain't? Well, lad, that ain't yer forlt,

'Cos sum wot'as can joar,

But few on 'em arahnd 'ere knows

Th' corse o' this 'ere woar;

Them Boars they bru't it on thesselves,

Ther' aint th' slitis' dahbt.

Fer wipin' sumfink orf a slate

Ahr 'Tommies' wiped 'em aht!"

Then thought "Wild Will o' Wimbledon"

His chance had come to score.

"What was it they wiped off the slate?"

He asked the wily "Boer."

"I dunno' wot it wos," said Bill,

Too shrewd to make a plunge;

"I only knows they wiped it orf,

An' then fru' up th' sponge. 
Me nevry in th' Nary 'rote

As orl wos lookin' gay,

'Cos orl th' fleet wos guardin' ov

Th' mines at Kimberlay.

'E sed Th' Orange Tree State wos

Surrahndid by 'is ship,

An' 'ah they nabbed th' oranges

An' giv' th' Boars th' pip.

They tuk a million pris'ners w'ile

Ole Kruger sed 'is grace,

An' shipped 'em orl wiv ' Uncle Paul'

Ter ole St. 'Elen's-place.

Ole Paul went absent-minded there;

'Is wits went aht ter rove,

'Cos Ruddy Kipper 'rote abaht

"Th' Absent-Minded Cove.'"

"Why don't they shoot the prisoners, Bill?

'Twould be far less disgrace

Than cooping up a million men

In Old St. Helen's-place."

"This 'ere aint Julia Seezer's time,

W'en th' pris'ners wos shot,

Tho' sum desarves it w'en they shows

Th' w'ite flag w'en it's not."

"I'm told of half our trouble there

Bad shooting was the root."

"Thay can't 'it 'aystacks," said the "Boer,"

"Wot aint larned 'ah ter shoot. 
Ahr sodgers missed them Boars at fust;

But wot seems werry strange

Wos w'en they sent a Kitchener aht

Ahr 'Tommies ' fahnd th' range."

"I'm told you 'guyed' The War Office,"

Was Will's next " feeler" sly.

His clay Bill wetted, and upon

The bar he drew a guy.

"I allays drores attention ter

Th' sort o' mugs they be

Fru' that dishmountid scan'al an'

'Cos they rejuctid me.

I wolunteered, 'cos on good beer

No Brutisher 'ud shirk;

Th' army-doctor tole me, tho',

As ale 'ad dun' its work.

'A libel on $T h$ 'Boar's 'Ead beer!'

Phil Philpot sez, sez 'e.

'Nah me an' you gits damages

Fer libellin' you an' me!'

"I finks as 'ah that Woar Orffice

'As blundered; it's a sin,

But w'en I 'roted to $T h$ ' Times

They didn't put it in!

Then sum'un brings a letter wot

'E sez cum from Pell Mell,

W'ich arsted me ter call an' see

Sum millingtary swell, 
They arst me if I sported this

Ole Union Jack fer fun.

Sez I, 'It's 'cos th' colours, lads,

Wos nivver known ter run!

Th' pattern's rayther ancient? Yuss,

Not made ter change abaht.

It ain't afraid o' water, 'cos

Its colours won't wash aht!

If scahts is wot yer wants,' sed I,

'I've got 'em ready made;

Ther's nun' can scaht fer coppers loike

Th' Bef'nal Green Brigade!'

Th' fick-'eads wudn't 'ear me aht-

'They orl seemed 'arf afraid;

Ter raise a wolunteer corpse wos

Th' offer wot I made.

I lorst a full 'arf bloomin' day

In Pell Mell w'en I call;

Th' bahnders 'ad th' cheek ter say

They didn't 'rote at orl!

Sed one, 'Ahr rubbish-yard's full up,

So let this guy escape!'

Sez I, 'I guess that rubbish-yard's

A yard o' your red tape!',

"You caught 'em there, Bill, on the hop,"

Said Wimbledonian Will.

"I guess I made them big bugs jump,"

With pride said Bethnal Bill. 
“Why don't you," Bill's disciple asked,

"Your grievance forward bring,

And get the Queen to take it up?

$I$ would-if I were King!"

“I sees yer've got a level 'ead,

A proper screwed-on show-

Yer don't a mind a takin' tips

From one wot's in th' know.

It's them ther' chuckle-'eaded torffs,

Wot little life 'as seen,

As finks as they knows better nor

Th' Boar o' Bef'nal Green.

They goes an' tries ter put me on

Th' Prince o' Wales as well.

I spotted, tho', they'd laid a trap

Like that 'un in Pell Mell.

I gits a letter arstin' me

Strite on th' Prince ter call,

W'ich I fahnd wos a plant, an' not

From Mulberry 'Ouse at orl.

They sent aht little 'Bobs'-acorse

Yer knows th' Bobs I mean,

'Cos me an' 'im wos schoolmates an'

Wos born in Bef'nal Green.

Me pal Tom Lipton lent 'is yacht.

Said 'e, 'Bill, arter all,

It carn't beat Uncle Sam, but it

Can 'elp lick Uncle Paul!' 
“Yer've 'eeard o' Bard'n Pal, a pal

Wot's werry fick wiv me-

Th' 'Bavin' Towel ' wot wiped aht orl

Th' Boars rahnd Meffykee.

We'll feast 'im at 'Th' Boar's 'Ead ' pub

Fer givin' Kruger beans ;

We're goin' ter 'ave a roasted boar's

'Ead, trimmed wiv Bef'nal greens.

Th' torffs wot 'rites th' Evenin' Noose,

Th' Eccer, an' th' Star,

They cums ter interwoo, an' treats

Me in 'Th' Boar's 'Ead' bar ;

An' one on 'em sez on th' list

Ov 'onners, wot 'e's seen,

They've got me name guzutted as

'Th' Earl o' Bef'nal Green.'

I reckins my ole woman, tho',

Ain't kep' th' title dark;

She sez she'll be a earless, wiv'

A 'ouse inside 'Ide Park,

A-takin' dahn th' dookissis

(Sal's jus' th' gal wot could!)

An' cuttin' aht th' countissis

Wot's in St. Johnny's Wood.

Sal's got a speerit on 'er own, She's full o' speerits, lad,

'Cos she's 'ad moar conwictions nor

Jane Cakebread ever 'ad! 
She's ov a good stock, too, 'cos she

Wos wunst th' Corster Queen,

An' Sal discindid striteways is

From 'Bess o' Bef'nal Green.' "

"Things look a trifle black with White,"

Suggested shameless Will.

"O W'ite can tak' care ov 'isself-

But wimmin carn't," said Bill.

"Fer shootin' shemale gen'lefolks

Them Boars shu'd git it stiff,

'Cos ain't they bin a firin' shells

At poor ole Lydy Smiff!

Ther's sum as ought to suffer fer

As 'ah they treated 'er.

I'll tak' it aht o' sum o' them

'Ere furriners rahnd 'ere.

Th' fust fight wot we 'as I'll kill

A blessed pedlar dead

For ev'ry blessed 'air as growed

On Lydy Smiffy's 'ead!"

(Prophetic words indeed, brave " Boer"!

'Twould seem thou hadst foreseen

The climax to that night's dark work-

That mad, terrific scene,

The dread ordeal, the awful trial

'Thro' which we soon would go.

Had we but known what lay before!

Alas! we did not know !)

* $\quad * \quad$ * $\quad * \quad$ *


"Aud how's your nephew, now ?" asked Will, Then wished his words unsaid.

Bill Bludgeon fumbled with his pipe, And turned aside his head.

“Ah, lad! Jack's name wos on th' list

O' lads wot's dun' the'r best,

But - w'en th' boys cums marchin' 'ome

'E won't march wiv' th' rest.

Woar ain't orl beer an' skittles, lad;

Wot touches ov th' spot

Is w'en yer lose a frien' an' 'im

'Th' only one yer got.

It breaks me 'eart ter fink I'll see

Th' bonny lad no moar,

Wot cheered 'is poor ole uncle up

Wiv' noose abaht th' woar.

Th' blokes is kinder nah, 'cos they

Don't chivvy me th' same,

They don't chi-ike me dahn th' street

An' 'oller aht me name."

Then answered Will, "You take my word

(And take my hand, old son),

Of those who've lost an only friend

You're not the only one.'

* * * * * * * 
The "beer and skittles" find no place Where's played the game of war;

The sport remains for those who're left

Behind - and oft the scar.

Full many a heart with hope beat high

To welcome England's best,

But found, alas! that some dear one

Did not "march with the rest."

The flaunted flag, the fife and drum,

The measured tramp, the fame,

The rousing cheer-the prelude form

To conquest's glorious game.

But comes the time that measured tramp

A funeral march would seem, And out of tune the fife and drum, The fame an empty dream. 


\section{XVI.}

\section{War̨-Słamps Extraorydinary?}

From Mars to Philatelia

Bill now I tried to lead-

It maybe on the fatal plan

Of “ Much haste, little speed."

I mentioned Philatelia, but

It proved of little use,

For Bludgeon thus unconsciously

Her fair name did abuse :

“Who's this 'ere Filly Tilly wot

Paul talks so much abaht?

That 'e's a good judge ov an 'orse

I ain't th' slitis' dahbt.

I'd like to 'ave a bit on; if

Th' Filly's one to stay

I'm on th' job-so 'elp me bob,

I'll have a bob each way!"

Then gently I explained that

Fair "Philly" was no horse,

Tho' safe to put one's money on,

And bound to stay, of course. 
"Her name," said I, was "short for Stamps."

Then, having broke the ice,

I plunged the subject into, thus

Forgetting Paul's advice.

As gentle hint, Bill forward then

His empty pot did push.

"Yer're cummin 'ere ter waste me time,

A-beatin' rahnd th' bush!

I fort yer wanted fer to 'ear

Me speak abaht th' woar,

But if it's Stamps yer wants why ain't

Yer mentioned it afoar?"

Paul saved the situation here,

For he re-filled the pot.

The subject nearest to my heart

I'd broached, and nearer got.

Yet not too soon from off his track

I'd try "The Boer" to shunt,

Who lied as well as any

"Correspondent at the front."

Tho' Paul now whispered, "Shunt him on!

Or leave the track he won't,

You must have got the needle!' But

I failed to see the point.

"That's needless-I don't care a pin,

So please let me alone!

Bill's unofficial war-news has

A charm that's all its own." 
Paul to a certain place consigned Myself, but I said, "Well, Why should I go to-Halifax ?"

But why, he could not tell.

"Now, please remember that you're not

(I spoke in haughty tones)

The only pebble on the beach-

You're not the only Jones!"

Paul left us, and the "Boer" forthwith

Produced a leathern pouch

That held War-Stamps and other Stamps,

Unique indeed, I'll vouch.

Upon the bench we spread them out,

Then I picked out the best,

For which I gave the "Boer" five "bob" -

And now I'll give the list :-

A dozen Transvaals, $£ 5$ green (I'm holding for a rise!), With V.R.I.'s without the dots, and dots without the I.'s.

This lot contained an "error" ('twill be rarer by-andbye)

A V.R.I. without the V., and minus R. and I.

An orange Orange Free State, showing on the orangetree

An overprint-" "The late O.F.S., now the O.R.C."

(This novel overprint was, like the Burghers, "up a tree.") 


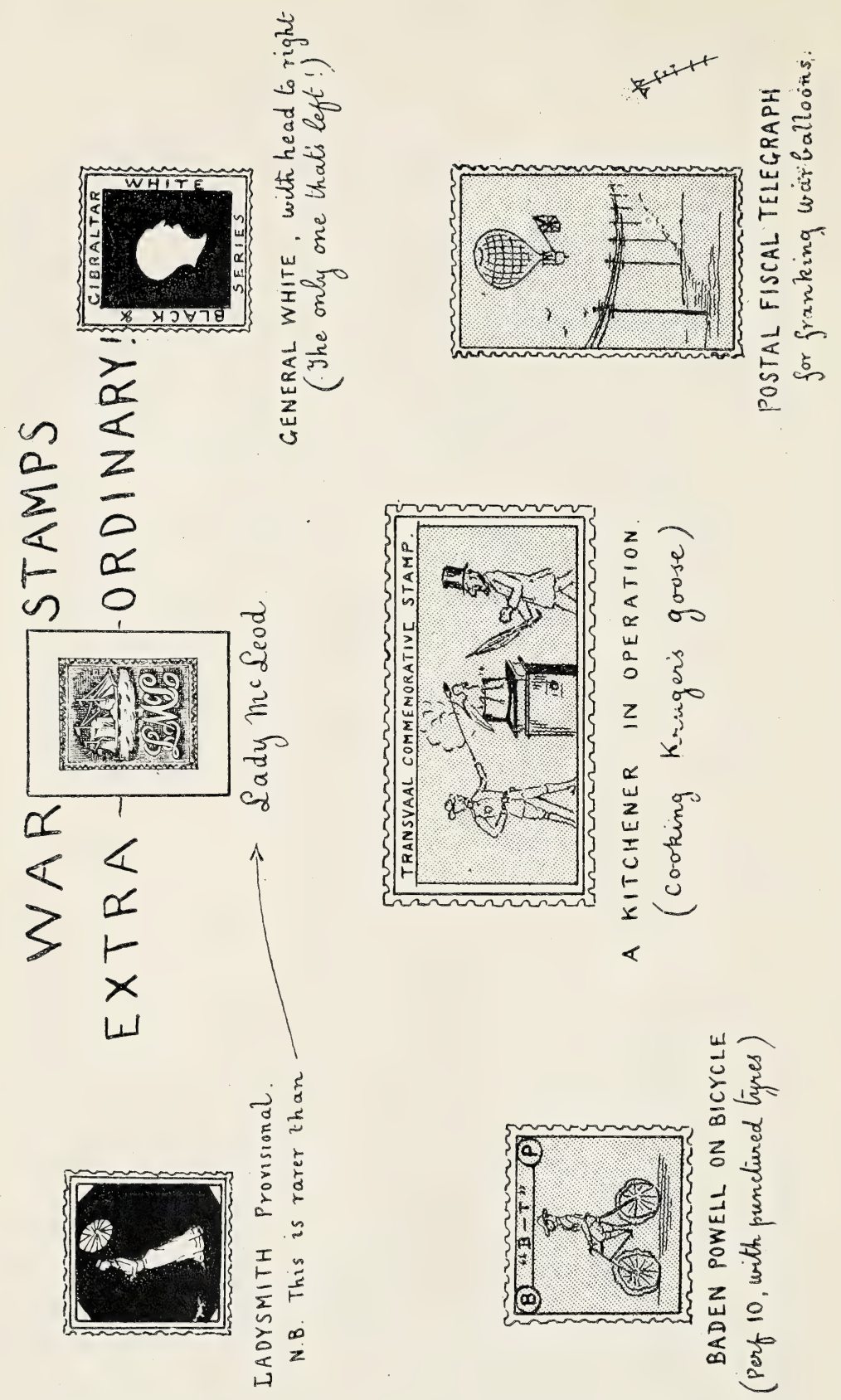
A set of seven postal-fiscal "telegraphs" (What coons Are half the War-Stamp specialists!) for franking warballoons.

No speculative issue these for those who specialise,

For, tho' not yet " inflated," the "Balloons" are bound to "rise!"

They will not "drop"-no matter what the wary Phil opines

(The only Transvaal stamps that drop are stamps dropped at the mines).

A Transvaal overprinted with a figure ('pon my soul!)

Of "Bobs" in full war-harness-but without the shafts or pole.

"Bobs" wears a Cape, which makes me ask, apart from "fakers" " jobs,

To such a Stamp what says the other Roberts-Vernon Bobs?

A " picture-set," from whose wide range of subjects did I choose

A Kitchener in operation, cooking Kruger's goose;

With Kruger in a stove-pipe hat, and-what was stranger still,

Tho' certainly not out of place- the stamp had got a grille

A Ladysmith in brown-and-green on black, with Whie relief

(Rarer than Lady McLeod-at least, that's my belief)--

Ladysmith is watching with relief the dawn of day.

(Would such a "copy" come as a relief to Daun C. J. ?)

L 2 
Gibraltar's rare provisional (poor Ladysmith bereft!) With bust of White with head to right-the only one that's left.

A very "scarce" gray Kruger's Head, with hairlines, just a ferv.

The face looks very much cut-up, and also rather "blue."

A Baden-Powell, on bicycle, perf. ten, with punctured tyres (The watermark's a "Bathing Towel," supported with barbed wires);

On safety paper's B.P's "safety" (tinted orange-peel), A "Rhodester" pattern Mafeking, fitted with Free State wheel.

"This last looks rather doubtful, Bill. The front wheel isn't true, And that blued safety bleute-well, I half suspect the blue."

"Wot bloomin' rot yer talkin', nah; That Bad'n-Pal's orl gay-

$I$ 'ad it orf B.-P. 'isself, Wot sweared it was O.K."

“Well; that's a guarantee, of course ; But what about the rest?

Have any dealers seen them, and How did they stand the test?" Bill's next and naïve admission raised

My throat in quite a lump:

My five "bob" capital was sunk-

I'd visions of a "slump." 
Bill said he'd called when in the Strand

(The day he'd stormed "Pell Mell")

At two or three stamp-dealers' shops,

And tried these stamps to sell.

"I showed 'em Peckitt fust ov orl, Who'd peck at 'em, yer'd fink, But as 'e 'didn't touch them sort'

I didn't touch 'is chink!

Giwelb wudn't look at 'em at fust

('Is shop I chanct ter pass),

But w'en 'e did 'e looked at 'em

A long time fru' a glass !

Sez 'e: 'They're werry prutty, but

I dunno wot they mean.

Wos this lot made in Germany

Or made in Bef'nal Green?'

I 'ad 'igh words wiv Hadlow nex',

An' wish I'd laid 'im low

Fer sendin' fer a copper jus',

'Acos I wudn't go !

The nex' I tries wos Gibbons, but

I didn't git no show ;

An' werry fly I fahnd 'is birds-

'Cos Hiscox giv' a crow !

I jus' goes in an' arsts 'im-jus'

As ciwil as cu'd be-

' 'Ah much ought I ter git for them?'

'Abaht six monf's!' sed 'e. 
'E shoves me w'en I tries ter take

'Em in ter C.J.P.-

Tho' I guess I'm as Bright as 'im An' knows me 'A.B.C.'

But w'en I goes acrost th' road Yer'd fink, th' way 'e cussed, As Oliver wos Cromwell, an' Th' Boar wos Charles th' Fust!

I called on Ginn, but won't agin ;

'E sed I'd made (th' snipe!)

Two lydies faint in 'is shop fru' A-smokin' this 'ere pipe!"

"Try Alfred Smith ?" “I did," said Bill,

"But 'ad ter tell 'im strate-

'Yer're only bloomin' Alfred Smiff, An' not Alfred th' Great!'

W'en 'e sed, 'Go to Lincoln!' I

Sed, 'Who's ter pay me fare?

D' yer fink I'm goin' ter take 'em all Th' way ter Lincolnshare?'

I arst J. Jones ter take 'em on, Sed 'e, 'You take 'em off!'

So then I tries anuvver one, An' sez ter Myerscough,

'Yer've bin this biz in long enuf

Ter know yer way abaht.'

'E looks me up an' dahn, an' sez, "'Ah long 'ave you bin aht?' 
This ole pipe mad' 'im cough (Bill's Stamps

Would not 'make' Myerscough!),

W'en Hamilton-Smith nex' I see

'E starts a takin' snuff!

An' Bluett sed as 'e'd be blowed

If I sh'd draw a sub,

'E sniffed an' sed, 'Yer'd only go

An' blew it at th' pub!'

I tries ter plant th' lot on Shiells

(Th' Shiells spelt wiv a Ross),

Sed 'e, 'Well, if yer lose 'em orl

No one'll feel th' loss!'

I finds a Field that wosn't green, But 'wider' than th' door,

I've laid th' field-but this Field tried

Ter lay me on th' floor!

Ter Marchant I march in an' arsts

'Is name, sez 'e, 'March aht !'

An' Pemberton's a member, too,

Wot knows 'is way abaht.

Sum' sez, 'Try Brown, o' Salisbury!' But

Yer 'as ter take th' train,

So I ain't yut seen Salisbury Brown,

Nor ain't seen Salisbury Plain.

I pops inter th' ole Bazaur,

Wot's called Exchange and Mart,

'I'm up ter seein' Upcott Gill,'

Sez I, 'If as 'e'll part.' 
I tumbles in a room w'ere sits A cove orl quiet an' still, Them Stamps quite upset Upcott, tho', 'Cos up got Upcott Gill!"

What if - the thought was horribleWhat if I'd paid the "Boer"

Five "bob" for this "lot," worth, may be, But fifty "bob" - no more!

Dealers are only mortal, tho', And War-Stamps may deride, When even such an expert as Myself could not decide.

Was Paul the fool who'd put up Bill These "gems" to try and sell?

"I tole yer as I seed them shops W'en marchin' ter Pell Mell."

Then deeper still I sounded Bill. The rivals most I dread In "Transvaals" did I name, and, lo ! He knew them all, he said!

Bill claimed acquaintance intimate

With Transvaal specialists.

There wasn't one he didn't know Of such Philatelists.

Said he, "I finks at Croyd'n Nex' Toosday I shall be, 'Cos Mr. Nankivell 'as bin An' arst me dahn ter tea." 
“Don't-don't go, Bill!" I pleaded hard.

"The journey's long and dear.

Why pick up friends afar?-You prize

Dear friends too cheaply here!

The big Collectors thousands have

Of each Stamp you can show.

Don't take offence - take my advice

For your own good-don't go!"

"I won't," said he, "if wot yer sez

Is true." Said I, "It is."

"Tho,", added Bill, "this five bob ain't

A werry payin' biz,

It's 'arf a bloomin' pedlar's price!"

The time, I now discerned,

Had come to change the subject. Read

How I the subject turned! 


\section{XVII.}

\section{Grim Pets.}

"You don't think much of pedlars, Bill?" Said Bill, "I 'ates th' name!

I finks if yer knowed wot I finks As 'ah yer'd fink th' same.

Ter 'awk abaht an' cry 'Ole clo!'

Is orl they're fitted for.

That's wot I finks o' Spitalfiel's !"

And Bill spat on the floor.

"It's them ther' furrin' 'arf-breeds wot's

A-ruinin' ov th' land."

“Free trade's another curse!" said I.

Said Bill, "Giv' us yer 'and!

Paul's ri'te w'en 'e sed yer're a brick'Cos, strite, yer're jus' me style.'

I, looking up that moment, caught Paul's grim, approving smile.

“It ain't me forlt 'cos I ain't took Th' field, 'acos I tried;

But I can do sum fightin' 'ere

Ter stem th' furrin' tide. 
Wiv them ther' alleyan pauperses

Ther's 'ardly room ter crawl, 'Cos that 'ere 'Abus Paupers' Act

Don't seem ter act at all,

If I pegs aht a-fightin' fer Th' rites as wot we for't,

I'd like ter fink they finks o' me-

I finks as 'ah they or't

Put on me grive sum epigraf,

Like sum as wot I've seen-

'Not dead but on'y gorn afoar;

'E died fer Bef'nal Green.'”

"Do you know one called 'Pedlar Jim '?" Bill grimly sucked his pipe,

Then answered, "Yuss, Jim 'anged rahnd 'ere

For monfs-th' dirty swipe!

I 'eeard as 'ah they wanted 'im

Fer cuttin' ov th' froat

$O$ ' some ole genelman's wally, wot

'Ad pinched a gray fur-coat!"

* $\quad * \quad$ * $\quad * \quad$ *

Then something soft my shoulder rubbed.

A low, deep, purring sound

I heard, and then I turned my head, And close beside me found 
A black tom-cat of startling size,

With bright green eyes, whose glint

Was rendered more expressive by

A fixed and awful squint.

I'm fond of cats (they tell me that's

Because I lack a wife),

But ne'er had I seen such a cat,

So huge, upon my life!

We seemed at once to " hit it," and,

Our friendly greeting o'er,

The "Thomas" quietly perched upon

The shoulder of the "Boer."

"Ole Grim an' me's ole pals," said Bill,

" 'Is folks from 'Oundsditch cums.

Grim tuk fust prize, an' 'e wos called

' King o' th' 'Oundsditch Toms.'

' $\mathrm{E}$ got 'is poor nose battered in,

W'ich made 'im cross-eyed, strite !

W'en sum darn pedlar kicked ole Grim.

In this 'ere bar one night.

Grim knows as 'ah who dun th' kick

Wos one o' them ole clo's.

'E's waitin' fer ter wipe it aht-

'Cos 'e carn't wipe 'is nose!"

(You'll soon hear how Grim wiped it out,

And then his case, you'll say,

Does not require reporting to

The R.S.P.C.A.) 
Just then a bark, a bulldog's bark

(I know the "whoop" too well

To e'er mistake it), sounded, and

I muttered, "There'll be hell!"

But no, a big "bull," called The Pup,

Was soon beside the cat-

That is, he made for Bill, and on

His vacant shoulder sat.

"Them two is pals," said Bill, "'cos Phil

'As bin an' trained 'em boaf.

I don't believe yer've seed the'r match-

Not if yer tuk yer oaf!

They boaf on 'em can take the'r beer,

W'ich shows the'r human powers.

Lars' week they fines 'em forty bob

Fer drinkin' after hours.

Ther's in the'r weins a cat-an'-dog-

Like mixture sort o' bleed;

They stan's up fer each uver w'en

They sees as 'ah ther's need."

Bill into details went which quite-

As far as I could see-

Put in the shade Paul's history of

Black Bess's pedigree.

"Grim's murver wos a Persian she, 'Is dad wos 'Oundsditch Tom; That's w'ere 'e gits 'is good looks an' 'Is fightin' 'abits from. 
Pup's ma wos pals with Grim's acos

They used to share an' share.

W'ile one went shoppin' t'uver used

To suckle boaf th' pair."

I, who made friends with Grim and Pup

And stroked and patted there,

And treated each to dainties from

The Boar's Head bill of fare,

Did little dream how, later on,

Our dangers they would share,

Or how devoted to The Cause

Would prove this noble pair!

* $\quad$ * $\quad$ * $\quad * \quad *$

Bill's "peep show" was the item first

In this queer "benefit."

"Yer see this 'ere Queen's Choc'late box?"

All eyes were fixed on it.

The box he opened on the floor,

And, as the "boys" stood round,

The vilest creature nature knows

Inside that box was found!

My pet aversion is the kind

Of pet Bill took in hand-

A spider, of a size, thank God!

Ne'er met with in this land. 






Alive it was. If there I stayed

I felt my heart would stop,

"This 'ere's th' werry spi'," said Bill, "They found on Spider Kop!"

To me- " If yer strokes Leggy, lad,

Yer'll find 'e ain't afraid.

But don't yer git a-pinchin' 'im!"

(Then for the door I made.)

"I knows as I can trust yer, but

Yer 'ardly wu'd believe

As sum bloke tried to pinch 'im once

An' slip 'im up 'is sleeve!

$S p i$ ' takes 'is meals at table like

A Christian wiv a bib.

Yer ought to see 'im dossin' wiv'

Ahr baby in 'is crib!"

The curse of overcrowding here

Shown up was by this boor-

What horrors are inflicted on

The children of the poor!

Now, when the Pup the spider saw,

The dog, who turned quite pale,

Did not show fight, but showed his teeth,

Then, turning round, turned tail.

He trembled-you could plainly see

The tremor down his spine-

He sniffed, then raised his head and gave

A long and piteous whine. 
E'en greater terrors Leggy had

For Grim than for the Pup.

Grim tore around the bar, and then

The chimney vanished up!

Then from the roof a chorus rose

(Which only raised Paul's smiles)

As Grim described the horror to

His cronies on the tiles.

'Twas feeding time, and Leggy took

His supper on the bar.

Loud laughed the "boys," but I to smile

Disgusted felt too far.

That awful, crawling "beauty" was

To them a thing of joy

The while the vermin wrestled with

A Boar's Head saveloy.

I rated Paul. " My dread, you see,

E'en God's dumb creatures share.

This first 'turn's' given me a turn.

What other 'turns' appear?

Upon my oath (despite The Oath!)

To fly feel tempted I."

"You're far too 'fly' for that," said Paul.

(The spider and the "fly.")

Again I failed to dream what part

A creature dumb would play

When all would rally to uphold

Fair Philatelia's sway. 
Had I foreseen I might have been

Less prone harsh terms to drop,

Have looked with less aversion on

The thing from Spider Kop!

"All right," said Paul, " the next turn will, I fancy, turn your head.

Two serio-comics I've engaged

Who're 'swells,' their agent said.

They're ladies and Philatelists,

Whose mission's said to be

To make the stage a platform to

Promote Philately!

Ah, Will, I knew you'd brighten up.

But-mind-I'll have no pranks!

You are so weak where women are

Concerned!" I muttered, "Thanks!"

"Now, lads," cried Paul, " our concert's on.

Here, Bill, you lead the way.

And, Philpot, don't belie your name!"

Said Phil, "I'll make all gay!" 


\section{XVIII.}

\section{fi pąilatelic Concertyt.}

Into the Concert-hall they filed, The followers of "The Boer," Bill Bludgeon's Boar's Head Bodyguard Of forty thieves-or more.

A stage was at the far end, with

A Broadwood at the side, At which, with fingers fat, yet deft, Phil Philpot did preside.

Footlights and all! (On that same stage At least one brilliant "star" Of London's music-halls " came out"

Ere winning fame afar.)

The item first the programme on

With skill did Philpot playAn overture of popular airs-

Pathetic, "comic," gay.

"Yer sit nex' me," said Bill. I asked, "Where's Leggy?" Said the "Boer," "I left ole Leggy lappin' up Sum four ale in th' bar." 
I felt relieved. Then added Bill, “'E's upset Philpot's cat,

Fru' catchin' ov free mouses an'

A killin' ov a rat!"

Said Paul, "A brougham's outside, with

A lady, I suppose.

I'm thinking, Will, at such a 'turn'

You won't turn up your nose."

He handed me a card on which

I read-what could it mean?-

"Miss Lily o' Killarney" (the

Late Sandwich Islands' Queen).

“That name's her stage-name," whispered Paul;

"The title, tho', 's her own.

She's touring round the world until

Her troubles o'er have blown."

"What! Liliuokalani here,

With Philatelic songs?"

"That's so," said Paul; "she's on the stage

To ventilate her wrongs."

The orerture just ended as

A page-boy smart appeared

And handed Phil a music-score.

(The forty thieves all cheered.)

Mine host a prelude started, wit_

A haunting, sweet refrain,

That had, in rhythm, swing, and run.

A Leslie Stuart vein. 
And then there stepped upon the stage

Indeed a perfect Queen-

A dusky, soft-eyed beauty, one

Of regal style and mien.

Her face was prettier, fairer far

(Stamp-portraits oft belie),

Than pictured on the violet Stamp-

The two-cents of Hawaii.

And like, yet unlike, Likelike

Was Lil', I'd like to say.

I'd like to paint " The Lily" - tho'

Such task is hard alway.

“The Lily o' Killarney " had

Queen Kapiolani's style,

While I could trace, with added grace,

Queen Emma's gracious smile.

The "boys" at once all silent were

As burly Philpot played

The opening bar (accompanists

Like Phil are born not made).

The maid, young, creole-like, and slim,

With voice that clearly rang

Throughout the room, and thrilled us thro',

This ditty sweetly sang :- 


\section{LILIUOKALANI.}

From fair Hawaii, that's far away, A maid brings Stamps to sell, For she'd buy back from "Uncle Sam"

The home she loves so well.

To raise the fee she's doomed to be

An exile here to roam,

Till she can pay her passage back

To Honolulu's home.

Who'll help Liliuokalani

To catch the first mail-boat?

(Her stage-name's " Th' Lily o' Killarney"-

To catch the Irish vote.)

She cuts so fine her Sandwich "line,"

And charges nix for smiles,

If you ask no dis-you may ask to kiss

The Queen of the Sandwich Isles.

There's numerous "Numerals" going cheap,

And "Missionaries" rare,

In her late palace millions more

Has Lil secreted there.

A school they turned it into when

They turned her from its door,

But they can't teach the pupils there

What's hidden 'neath the floor! 
When fair Liliuokalani

Aboard goes that mail-boat

She's done with “Th' Lily o' Killarney"

(And hang the Irish vote!)

The dusky maid will break " the trade,"

Of dollars she'll make piles,

For "The Sandwich Trust" will make (or bust)

The Queen of the Sandwich Isles.

* * * * * * *

'Mid loud applause she left the stage,

"Paul, introduce me, quick!-

She's going:" “ Not a bit," said Paul,

"You'll meet in half a tick,

She's there-in Philpot's private box."

And I looked up to see

"The Queen "-whose lustrous eyes were fixed

On Paul-or was it me?

"Take her this bouquet!" (Paul's a brick

Where intrigues are concerned.)

The floral gift accepted was,

How sweet the thanks I earned!

In " half a tick" (I'm more than quick

At making (lady) friends)

We'd formed a friendship such as ne'er

In simple friendship ends! 
"I know you well," said she, and I Had not the heart to own

That she " had the advantage" (which

Sounds rather cold in tone).

My name, and Paul's she knew as well.

Said I, "Then call me "Will'!"

She did, and I in turn addressed

The beauteous Queen as "Lil."

Philpot had kept the " boys" amused

With a rollicking drinking song,

Of "Champagne Charlie" sentiment,

With chorus full and strong,

Then, in the lull that followed, Paul

Upon the stage did spring, And this bold Philatelie song In "Jingo" style did sing:

\section{THE PHILATELIC PRIVATEER.}

Paul Jones at school did boast that he would rule the roast, In getting Stamps his method, too, was queer, He traded, so they say, in a private sort of way, And, like his namesake, played the privateer. What Paul required he took-was never brought to book-

His victims knew his bruising powers too well, The lads knew what they'd cop if they refused to "swap," At Paul's own price they had to buy or sell. 
Now men ask, whom Paul in their school-days had banged, "What happened to Jones - is he drowned yet or hanged?" But neither by water nor drop did Paul die, I've reason to know it-and I'll tell you why :

I'm Paul Jones, and I make no bones

Of making it to everybody clear, That I'm Jones, the only Jones, The Famous Philatelic Privateer!

In after life the same Paul played the bluffing game,

I've seen him paralyze an auctioneer,

Who, dreading Jones's frown, a "lot" he'd just knocked down

Put up again to please the Privateer!

That Paul could mesmerise, and cow, or hypnotise

E'en dealers stamps him as an awful rogue;

I've known them hesitate their usual price to state,

And sell him Stamps at "one-fifth catalogue."

When dealer meets dealer the first thing they say

Is "on the q.t. have you seen that P.J.?"

Whilst rival collectors ask, "Why won't he die?"

But no one's yet killed him-and I'll tell you why:

I'm Yaul Jones, and I make no bones

Of making now my famous title clear,

For I'm Jones, the Stamp-Fiend Jones,

Who caused his school-mates many a private tear! 



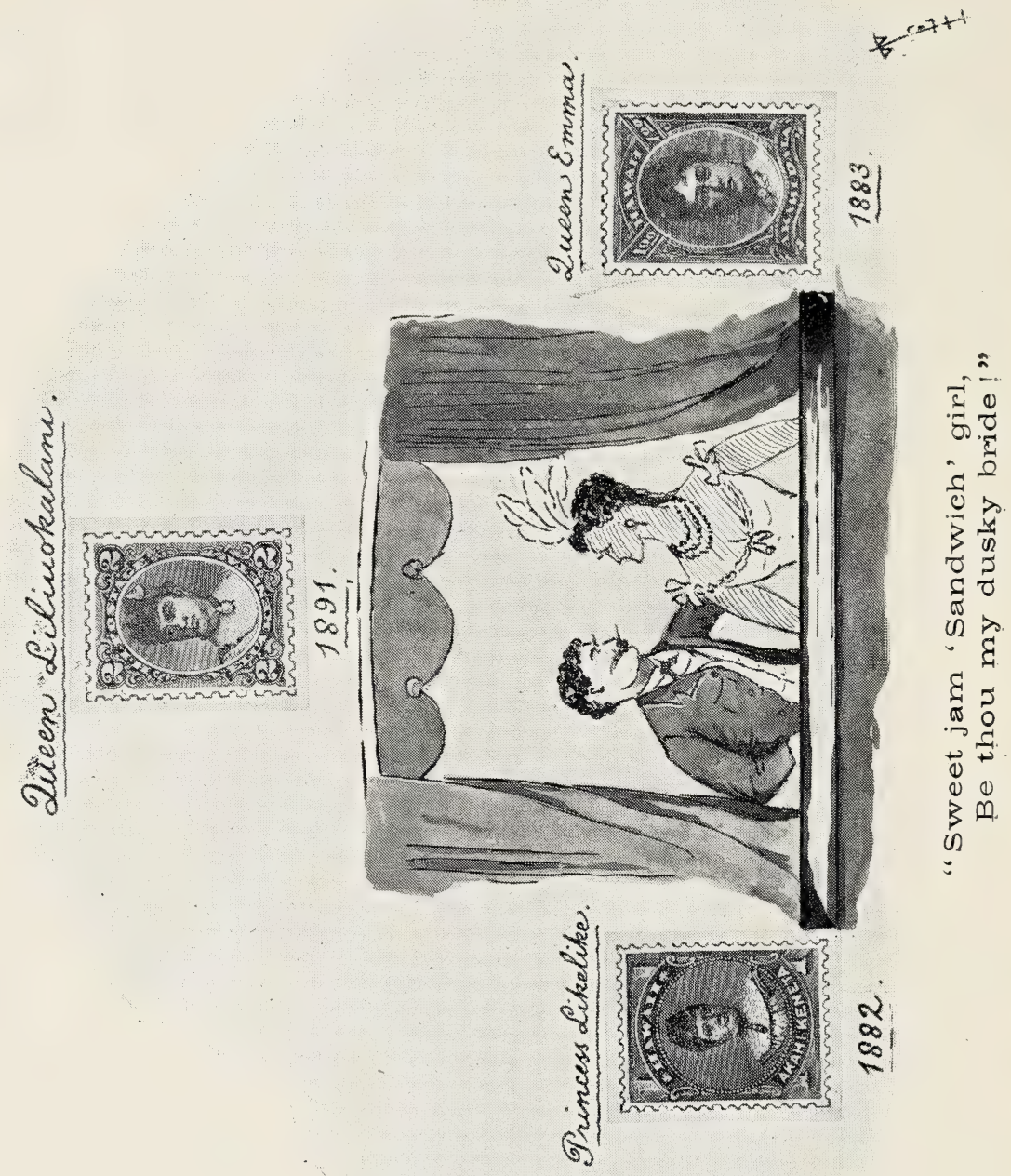


Paul "knocked 'em," as the phrase goes, with

His dominating style,

Altho' his subject was, at least,

Above their heads a mile.

But Liliuokalani did,

Throughout the song, her eyes

Upon him fix, and with a look, Methought, of pained surprise.

Does "Scotch" breed Irish eloquence?

Spoke I as ne'er before,

I called Lil " darlint-Norah and

Mavourneen and Asthore,

The Lily o' Killarney, and

My sweetest colleen bawn."

(This " colleen" was, without a doubt,

The sweetest ever born!)

And then impromptu, boyish like,

Did I confess my love,

I made my maiden Cupid's speech

To that fair, sun-tanned dove.

For in the box's dark recess,

As we sat side by side,

I whispered "Sweet jam-Sandwich girl,

Be thou my dusky bride!"

To seal the contract (ere 'twas made)

Her sealing-wax hued lips

My own had pressed-but she held back

And tendered-finger tips! 
Now these, however dainty they, Were not quite what I sought.

Alas! we're not as gallant as Our fathers were, methought!

"Say-to how many women that Same story have you told?"

A ring familiar in her voice There was, and something cold.

"Another lady here to-night You'll meet, gay cavalier, But I must go, adieu." And she Did forthwith disappear.

Well, women are queer creatures, but I'll trust the sex no more. Just then the "boys" were calling for A song-and from "The Boer." "If I sings 'ere," said Bill, " I'll lose Me contracts at the 'alls." He did sing-with a verse on Stamps. (A queer request of Paul's.)

\section{THE BOER O' BETHNAL GREEN.}

Ole Lunnun tahn's a-goin' dahn, she ain't th' tahn she wos, I'm dead agin' all changes, an' I'll tell yer why, becos She turns aht all th' best o' bone an' muscle boys she 'ad An' takes in sloppy furrinners, wiv'aht no 'eart or 'ead. 
Th' Cockney lad fru' orl th' world 'as allays 'eld 'is own, An' uvver people's also, w'ich 'e nivver lets alone.

In orl ole Inglan's battles, orl 'er wictories, I mean, Th' flow'r ov Inglan's army, lads, wos bred in Bef'nal Green.

I finks a cove sh'd fink afoar 'e talks abaht th' Boar, Th' Boar wot's in th' Transywale, I mean, 'Cos, yer tumble, as a sample ov th' best 'uns at th' woar Is th' sort they calls Th' Boar o' Bef'nal Green.

No matters w'ere yer wanders fru' th' globe or in th' earf, Ther' ain't a place wot's in it wiv th' birfplace ov yer birf. Sinst I wos born, an' long afoar, no uvver place I've seen, I've 'ad me day on 'Amstead 'Eaf'-but slept in Bef'nal Green.

Th' gilt is orf th' ginger-bread, fru' orl th' furrin' breed, It fairly takes th' cake th' way they takes th' bread we need; To-night th' flag o' rewolution wavin' will be seen, An', fank me stars, th' fust place w'ere it's riz is Bef'nal Green.

I finks a cove sh'd fink afoar 'e talks o' ciwal woar, It won't be werry ciwal w'en it's seen,

Wiv ruckshuns an' dishstruckshuns sich as nivver wos afoar,

W'en they rallies rahnd Th' Boar o' Bef'nal Green.

I pops into a Stamp-sale, 'cos I ain't no Stamp on me For a letter to th' missis-wot's at Soufend-on-th'-Sea. They arsts if I'm Phil Atterlist. I gives me chin a rub. “Th' only Phil I know's Philpot, wot keeps Th' Boar's. 'Ead pub." 
It leaked aht who I wos an' then they makes a rush fer me,

They swarms arahnd me fick as flies, as fly as fly c'ud be. They arsts fer Orange Trees an' Transywales an' V.R.I.'s.

Sez they, "Wiv'aht th' dot." Sed I, "I'll 'ave to dot yer eyes!"

I finks a cove should fink afoar 'e talks abaht th' woar,

They mobbed me in a way yer'd nivver seen,

They shahts fer Orange Trees, an' Bad'n Pals, an' Maffykees

W'en they 'eeard I wos Th' Boar o' Bef'nal Green.

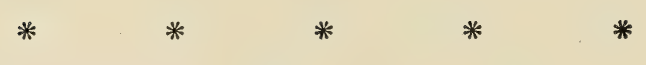

The song and singer, need I say?

Won thunders of applause,

Then Bill, about to make a speech,

Stopped short, and made a pause ;

His eye towards the farther door

Was fixed with lowering glare,

Two faces strange peeped in, and then

Did quickly disappear.

“Them's pedlars, yuss, by gum!" cried Bill,

"Ther's trouble brewin', Paul!"

Jones looked, I noticed, just as black,

The "boys" looked wicked all. 
But Philpot a diversion caused, " The last 'turn' in the show

Has just turned up-she's coming onMiss Philatelic Flo."

Said Paul, "I'm told that Flo has made A 'big hit' in the west,

That Stamp-songs e'er would reach the Halls

What Phil would e'er have guessed?

In opera, too, she's made a name,

In Faust she's going strong,

Flo brings in Philatelic 'gems'

In Marguerite's jewel-song.

We few who love our Science well

The ball must rolling keep,

For half of those who wish us well

Are really half asleep.

What $I$ and others do is done

To win no cheap applause,

We do it in-" Said I, "Just so,

In Philatelia's Cause."

“The Stamp and Stage Guild now outshines

The Church and Stage Guild quite,

A foretaste, lad, of what we'll do

You've tasted here to-night.

But take your seats! - the lady, lads,

Is just now coming on."

Once more, to Philpot's playing, stepped

A maid the stage upon. 
Fond heart of mine, now make thy choice

Between brunette and blonde.

Thou didst to "Lily's" wicked wiles

Too readily respond!

Miss Flo's the fairest maid e'er seen.

(And I have seen no few),

As I'm off with the old love, I

Can take on now the new.

Tho' fairer than "The Lily," Flo

Lil's sister might have been,

In form and face the double of

The Sandwich Islands' Queen.

With new-born love my tender heart--

My very soul was filled,

As I enraptured listened to

The song she gaily trilled :

\section{PHILATELIC FLO.}

In ardent Stamp-language may love's language sweet

In the future by lovers be spoken,

When ardent collectors love's vows will repeat

With phrase Philatelic as token.

Will Joe say to Flo, “My Stamps, love, you know,

Are rare 'uns not likely to 'drop,'

Then let's form a pair, and one album share,

And single for married life 'swap.", 
Flo, Flo, don't say no

To a stamp of man like me!

I will be true, for I love you

As I love Philately,

My love has reached high water-mark, I'd let Hope's " anchor" go,

And "crown" my hope with sympathetic,

Philatelic Flo.

"O ! this is so sudden!" of course Flo would say,

(Tho' the tenth time that Joe's put this "feeler!")

"We both live for Stamps-but papa, dear, would say

We can't live on Stamps-like a dealer!"

Then off Joe will trot to bid for this "lot,"

And capture pa's " copy" so rare.

He'll learn in a trice the big " reserve price"

Pa's asking for what Joe would share.

Joe, Joe, I say no!

With a stamp of man like me

To touch the heart you'll have to start

With collecting L. S. D.

Then when you've reached high water-mark,

And lots of mint can show,

By gum! but, Joey, you shall marry

Philatelic Flo! 
Followed the song a dance, with no

High kick nor trick of heel ;

Its dreamy style the poetry

Of motion did reveal

With dainty step and graceful twirl.

Flo's costume Worth's might be,

A dream in gaily-flowered silk,

With lace and lingerie. 


\section{XIX.}

\section{The Old, Old Stong.}

As Flo tripped off the stage my heartMy foolish heart-beat fast. Yes, I at length had met my fate;

This "case" would be my last.

So hit was I, some time elapsed

Ere thus my tongue I used:

"To that sweet serio-comic, Paul,

I must be introduced!"

Paul chuckled, "You're a beauty, boy!"

" She is," said I. "My lord,

I'd like a chat with Flo on Stamps-

That's if she'd not be bored.

Are serious collectors, tho',

Such serio-comics?" "Yes,

We call them 'serious chronics' for

Their chronic seriousness

I've never met the girl before,

So introduce yourself."

Of course I did as I was bid,

And left Paul on the shelf. 
She'd won my heart-to which I said,

"Down! foolish flutterer, down!

Be calm, or I shall lose you to

The sweetest girl in town."

Flo in the stage-box seated was.

I hied me there once more.

With smile she greeted me. Where had

I seen that smile before?

Then, with the old-world courtesy

That marks the Wylie race,

I raised and kissed her hand the while

I yearned to kiss her face.

"What think you of Miss Lily's voice?" Asked Philatelic Flo.

Said I, “ Her voice is rather high.

Her song, too 's rather low.

Those half-breeds are a trifle coarse ;

Their ways are much too free.

'Tho' coloured ladies some may please,

An English girl for me!"

Thus did I make the pace, I own

My form that night was grand.

Not only did I kiss, but I

Retained, the lady's hand.

The crowd had to the bar adjourned,

And there seemed like to stay.

We were "alone tugether" - as

The three-vol. novils say. 



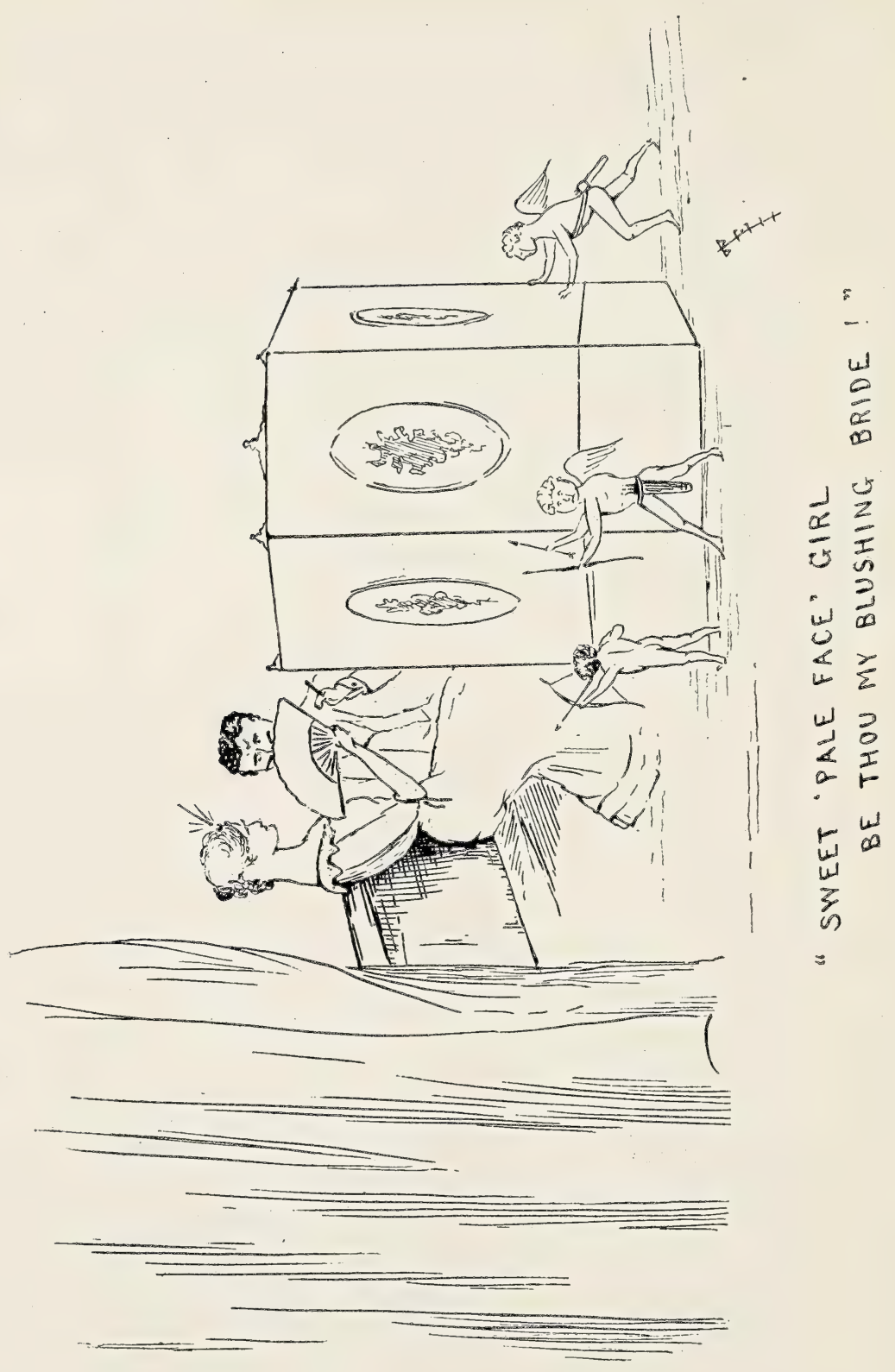


Oft history repeats itself ;

And so does love as well.

The old, old story once again

I prompted was to tell.

The dusky Lil forgotten was

As we sat side by side.

I whispered low, "Sweet pale-face girl,

Be thou my blushing bride!"

"Has no girl any prior claim

To whom your love is due?"

Said I, "I've met no girl I love-

That is, till I met you."

"Just think," said she. "Has in your heart

No former flame been nursed?"

I thought-and thought of Pauline; but

I answered, "You're the first!"

"Men were deceivers ever," she

Then sadly did reply.

"Some are; but I'm not built that way-

I never told a lie!"

"George Washington the Second, eh?"

In mocking tone, said she.

"At school," said I, " my love of truth

That nickname earned for me."

"You love me? On your honour, tell

Me truly, if you can-

On a Collector's honour-as

An English gentleman!" 
Then noble lines misquoted I

(For, thus revised, they score) :

"I could not love tbee, dear, so much

If I loved honour more."

"Honour and you are strangers, sir, And Lil and Flo are one!

I played both parts" (the lady rose). "With your false heart I've done!

Look, traitor!" That familiar voice!

I started back and reeled

As, casting off her golden wig-

Stood Pauline's self revealed!

* $\quad * \quad * \quad * \quad * \quad *$

She left. I followed but to see

Her step the brougham in.

"One word, Pauline!" A heartless laugh

Was all my plea could win,

Save that, as dashed her carriage off,

From Pauline's lips did fall

A warning and imperative

"Mind-not a word to Paul!"

Thought I this night of mystery

Prolonged would turn my brain.

I know not how-I found myself

Beside the "Boer" again. 
Said he, "I'd run a music-'all

Wiv' gals like that ter sing."

"You'd better run a pub," said I-

For I said anything.

“' Th' werry fing I means ter do,

Yer've 'it the nail. Wot $\mathrm{O}$ !

I've got me eye fixed on a snug

Free 'ouse in Kipper's-row.

I'd make a fortun', 'cos I'd make

(If my ole woman died)

Killarney Lil me barmaid an'

Miss Filly Flo me bride."

I rose, as rose within my breast

The Wylie chivalry.

Paul pulled me down, and sneered, "Pray don't

Display your jealousy!"

My jealousy! To rouse it had

That low-bred boor the power?

To think that that rank weed should dare

To pluck so fair a flower!

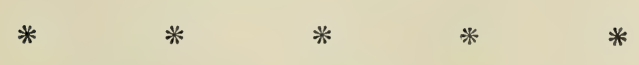

Into the bar " The Baron" burst.

His face was all aglow

With driving hard, his breath came fast,

Big drops stood on his brow. 
“ You've not a moment, Paul, to lose, (Here, Phil, let's wet my throat!)

'Big Birdcage Ben' is there to-night, And wears the gray Fur-Coat!

Ben fears there's treachery abroad. They've come prepared to-nightRumours have reached the pedlars of A rising-and they'll fight

If needs be. Each can well defend, Or dearly sell, his life,

Each carries, and can use, a long And murderous-looking knife!

This letter, Paul, the wily Ben Commissioned me to bring. He spotted me as One of Us. Here, read the blessed thing!" Paul tore the cover open, and After a minute said, "This is an ultimatum!"- then Aloud this message read:

"Sir, kindly let the bearer know How many friends to-night You'll bring - for our agreement was That you'd but one invite. Strange doings do we hear of, and Strange signs we see, what's more. What means, sir, your alliance with Our ancient foe--'The Boer'? 
Ben seems to fear you, Bill," said Paul;

Said Bill, "Yer bet 'e do.

'E knows I knows abaht that 'ere

Stamp-licence bizness too.

'E tumbles as wiv' orl 'is push

Wu'd fings go werry 'ard

If 'ah as I sh'd go an' blow

Th' gaff at Scotchland Yard!"

Paul with the letter calmly then

A fresh cigar did light.

"You'll place the 'boys' in ambush near Phils'-buildings, Bill, to-night,

And-mark me!-should you hear a shot

Your bodyguard call out.

A second shot - to rouse the East

You'll send out every scout!

Ta-ta, my lads. When next we meet

Will Bethnal Green be free.

It may not, boys, come off to-night-

But you leave that to me!"

As in the cab we drove away,

Destined were we to make

Such Philatelic History as

The World by storm would take! 


\section{XX.}

\section{Af the Stamp Sale.}

In minutes five was Houndsditch reached, And there did we alight.

To Percy's whisper Paul replied,

"It does not walk to-night!"

$\mathrm{O}$ ! fatal night for Stamp-Fiends' raid.

The fault was Paul's, not Fate's.

A fruitful source of trouble is The man who mixes dates!

And now Phils-buildings' ancient mart

We entered. Paul has well

Described it, so I need not, tho'

I'd briefly sketch the "swell"

Who, with suspicious air, received

A pair of harmless men.

Doves in the Eagle's nest were we,

Ensnared by "Birdcage Ben."

Hebrew was Ben, tho' not in speech.

He wore the Fur-Coat well.

Ben would go far to hold his own-

As far as I could tell. 
Square-jawed, and with the organ large

By which his race we know-

One of the true Mendoza type-

He'd prove an awkward foe.

Had Paul, if but in wits alone, At length his equal met?

Not he! He gripped Ben's hand, and said,

" That matter right I've set;

A Stamp-licence for this Sale, Ben,

The police have granted me."

Big Ben as pleased looked as a child.

How simple Hebrews be!

"But why hobnob 'The Boer' with?" asked

Big Ben with lingering doubt.

"I've squared him," answered Paul, " for he'd

The licence-clause found out.

Bill and his pals I've entertained,

And tons of money spent,

To reconcile the homebred with

The alien element."

"Well, all the Stamps are here," said Ben,

"And you can pick the same

At your own price, to clear, for it's

A risky sort of game."

"What price the coat you wear?" asked Paul.

Said Ben, "No price would be

Sufficient, for it was a gift

From Pedlar Jim to me! 
I'll leave you, gentlemen, awhile.

You in the meantime buy

What Stamps you like. I think you'll find

Our prices not too high."

He left, and on the pedlars' stock

We Stamp-Fiends made a raid,

And had the finest haul, I think,

Philatelists e'er made.

Russians and Poles galore were there,

And many a German-Jew-

The class who twenty in a room

Will live, and count it few.

"This sight," said Paul, " to action might

Our legislators rouse

An Alien Immigration Bill

To hurry thro' the House."

Did they know aught of Stamps, methought?

For strange cries reached my ears, ?

With terms familiar-technical-

That roused my doubts and fears.

Could ignorance be coupled with

Such technicality?

But, there, this night had been throughout

A night of mystery!

Each pedlar then his precious stock

By lantern-light displayed.

Such "gems" I saw that I at first

Stood paralysed-dismayed- 






Capes, Virgins, Tasmans, and Ceylons

In mint blocks, strips, and pairs!

"Here's richness !" murmured I, as might Some philatelic Squeers.

Beyond the dreams of avarice The treasures here for sale.

One turn around nigh turned my head. (Paul said it turned me pale.)

"Look like a philatelic sphinx, And mind your p's and q's.

Don't part with any cash if they Will take your I.O.U.'s."

To win our custom keen appeared This mixed and simple band.

Each vied with each, and shrilly cried The stock he had on hand.

Was it a dream? thought I. But no, The thought was too absurd, For I could see the Stamps I saw And hear the cries I heard.

Some folks to whom I've told my dreamsSo strange those dreams they deemedHave hinted that I merely dreamt. I dreamed the dreams I dreamed; But here distinctly I could hearAnd heard such cries as these:

"Imperf. Ceylons in blocks, unused, At any price you please!" 
The first " find" that I found I lost-

Or Paul lost it for me-

Ceylon's first issue fourpenny,

A block of ten, o.g.

The vendor's price was moderate:

"Five bob, sir, for the lot-

They ain't so dear at that." And I

Said candidly, "They're not."

Some say that opportunity

The bargain-hunter makes.

I take this opportunity

To say that version takes

A deal of beating in its way,

For Paul said, with a frown,

"If you'd stand high in their esteem

Lie low-and bate 'em down."

Another proverb-“Tread upon

A worm and it will turn."

I trod this worm on-but to prove

That even Paul can learn.

Face value offered I the Jew,

Who only said, "You git!"

Result of taking crafty Paul's

Advice-the "bater" bit!

A certain Baron would have bought

This block en bloc, I know,

Had I approached him. (Not as that

Fool Jones approached me, tho' !) 
Salon, Ceylon! That perfect block Had brought most men to terms.

A " block" like that had caught De WetAnd let alone De Worms!

In English next I did a dealThree mint Two-shillings brown.

A "bob" was asked. Said I to Paul, "I will not bate him down."

"Came next a cove who anxious seemed Of three hags to be rid.

“Who'll take three sacks of Penny-Blacks For half-a-crown?" I did!

"There's threepence on the bags," said he.

I forked out once again, For such " lots" come in handy if

You'd re-construct a "pane."

One handful showed five copies of The V.R. Penny-Black;

In time, no doubt, on these alone I'd “ get my money back."

E'en Paul himself said, " Not so bad! These in the cab we'll pop.

You hold them tight, and then you'll find The Pennies-Black won't drop. But (like so many ' niggers' whom Some Christian power tries To civilize from off the globe) The Blacks are bound to rise! 
But have you found the "error' that_-" And then Paul bit his lip.

He'd made what he himself would call "An im-Paul-itic slip."

So then I fired a random shot

That fair the bull's-eye hit.

" I'm looking for it now," said I,

With wondrous ready wit.

Then, off his guard, Jones opened out, "That 'error' don't you miss!

Fools think the V.R. very rare, The R.V. really is!

I've in my life found but a score."

(A "bloater" rare is Paul.)

Said I, "The scribes on English then

Are duffers after all!"

If thus, in their " exhaustive works," An "error" so pronounced

Omitted is, Paul's duty was

Those scribes to have denounced.

0 ! Pemberton and Westoby

And Philbrick! - there's no doubt

Your error of omission dwarfs

The "errors" you found out!

There must be some dark motive for This Black conspiracyConspiracy of silence as

Regards the Black R.V.! 
If Paul had found about a score How many, pray, had they?

Such methods ruin Philately-

I don't care what you say!

Then Paul said, "Mum's the word! Now, man, Don't chatter like a miss.

Don't tell your Philatelic pals

A single word of this."

Said I, " Pray don't alarm yourself,

I'm on the strict q.t.;

I'll tell my Philatelic pals

As much as they'd tell me."

I did not take Paul's word alone,

For that would be absurd.

We take each other's Stamps sometimes,

But ne'er each other's word.

Paul's full of errors, in his way,

Whilst I few " errors" miss-

To prove which, read the next verse (if

You've read as far as this).

My hand within the second bag

I thrust, then out I drew.

$I$ feared that I had drawn a blank,

All V.R.'s-nothing new;

But looking thro' my "draw" I found

A " find" my friend to pique,

Six R.V.'s on " original."

Paul growled, "Well, that's unique!" 
"Each for himself" 's a narrow creed; And I felt much concerned

To think that I must not impart The secret I had learned.

If truth lies in a well-ah, well, The well I fear's dried up.

'Twas hard for me, with my strict views, To drain this bitter cup.

The "strong in English" now would find Their weakness out, no doubt, In certain "lines" of line-engraved When my " find" drew them out.

I owned, if to my shame, I'd feel A Stamp-Fiendish delight

In slyly introducing R.V. Black to H. J. White. 


\section{XXI.}

\section{Recond Finds.}

When Paul asked, "Could you do a Bass?" Said I, "A sandwich too!"

Then, just to fit my words, there came

Two sandwich-men in view.

This strange announcement on their boards

Appealed at once to me :

"Old Sandwich Islands Stamps for sale."

"Paul, Ben's no fool, you see!"

Said Paul, "He's starting on his own,

And that must never be !"

A pair of two cents blue Hawaii

Fach board-man offered me.

Ben's was a bright idea, to set

This pair the part to play

Of common "sandwich-men," to hawk

A pair of rare Hawaii.

"These Sandwiches are more my line.

I'm tempted, Paul, to bite

At such a bait." But Jones replied,

"My thoughts take higher flight. 
I'm thinking of my uncle's coat Whilst you are giving your

Attention undivided to That undivided pair."

Ignoring this, I asked the price Of those two ragged "cards." "A bob a time, or eighteenpence For this pair and my pard's. Them's only samples, guv'nor, wot We takes around with us.

We ain't supposed to sell 'em ; but If ther's a chance-we duss!

These Stamps you'd think would fetch a bob; But, s'elp me Bob, it's true, To-day we 'awked 'em down the Strand. And Copthall Avenue.

It don't pay for shoe-leather, straight, And all our time's a loss.

We've both got in arrears, too, at The doss-house where we doss."

"Who sends you out with rare-I mean With common-Stamps like these? And have you no trade union to Command your proper fees?

It's shameful for two decent men,

As I perceive are you!"

Said they, "Big Ben would sack us if We joined the I.P.U. 
We only gets a bob a day

And com. on wot we takes ;

But that ain't much-'cos 'arf the folks

Believes our Stamps are fakes.

I tells Bill 'ere if things go on

As things 'as gone to-day

We'll both land in the work'us-and

I reckons we're 'arf way."

Enough ! It caused my blood to boil,

The sordid tale they told-

For blood boils quickly when the heart

Is young and far from cold.

"What little I can do I'll do.

This sweating is a curse!"

My heart went out to these poor men-

And then out came my purse.

A "Church-coin" was the smallest I

Could offer ; anyhow,

'Twas quite enough, for Ben did no

Gratuities allow.

They muttered something o'er my gift.

(P'r'aps in their hearts they swore)

'Twas something sounding something like

"'Ere's nothing something for!"

"A little help is worth a deal

Of pity, lads," said I.

"'Twill be a little help for you

If I your Stamps can buy;

o 2 
But eighteenpence is rather more

Than I can well afford.

Besides, you know, your price does not

With Gibbons' price accord.

They're really not your property.

But, there, we'll let that go.

And you for selling Stamps, my friends,

A licence cannot show.

Tho' I'll be out of pocket, still,

You're both out of a job,

And, tho' the Stamps are very old,

I'll take them for a 'bob.'

They spoke no word, those sandwich-men,

But, laying down their boards,

In lightning-rapid action they

Made up for idle words.

We three mixed up together seemed.

Thought I : “Well, here's a job!

They mean to kill each other! Are

They fighting for the 'bob'?"

By heavens! they were hitting me!

What else could I suppose-

With one blow in my left eye,

And another on my nose?

My wish had been to part them, but

Their action left no doubt.

I countered then with left and right,

And laid both ruffians out. 
The spokesman said, ere up they got “' 'Ere, guv'nor, keep the Stamps,

If only as you'll tell us 'ow

You got in them two clumps."

"I'll show you in the next round, lads, In half a tick or so!"

Said they, "Thanks all the same, boss, but We're off in 'arf a mo'!"

I paid them "five bob" for the pairs (And threw in what I'd taught).

For once I made Philately Take second place to sport.

"Your 'Bantams' Club' will crow," said Paul, "And proudly spread about

How two cocks, egged on, lay for you, And how you laid them out."

This was a record "find," indeed, Such record break who can?

I'd sell these pairs, for certain, to A certain Nobleman, Whose appetite for "Sandwiches" I'll whet when next I drop Across him-for, for two such pairs An Earldom he would "swap!"

So short the fight that few around Had noticed what had passed; But Paul the cool cheek had to say "Let this row be your last! 
P'r'aps, now you've had a lesson, you'll Create no further scene."

I gasped in blank amazement- "I Create-what do you mean?"

“No Simple Simon business, please!

You well know what I mean,

Your reckless generosity

Has brought about this scene!

We want no ' little wars,' sir, for

A big war here is due!"

'Twas half in jest Paul spoke, but more

'I han half he said was true!

"This comes," said I, “of slumming 'mongst

Your precious protégés,

You're quite at home with guttersnipes-

You understand their ways.

But I'll ne'er lift a hand again

'To help - at any price-

Your denizens of slum-land in

Their squalid haunts of vice!"

"Hark to the people's champion!" said

The Stamp-Fiend-Privateer,

"If this mob chanced to hear you, lad,

You wouldn't hear ' 'ear, 'ear!'

You're just that Tory-Demos, if

A lord 'dook' blacked your eye,

To go and spout sedition in

The wilds of Peckham Rye!" 
"I'm grieved, Saint Paul, to think how much The public's lost in you."

Said Paul, "I'm grieved to think that one

Black eye should change your view."

"You hold no views yourself," said I,

" With men your play's a cat's,

Poor pedlars you regard as mice."

Paul rudely answered, "Rats!"

"But there, you've not done badly, chum, You've helped The Cause," said Paul,

"They now won't ask too much for Stamps, P'r'aps some won't charge at all!

You've found the V.R. here, old boy, Also the rare $R . V$.

And well you've earned, tho' you ve not won The coveted V.C.!

The four Hawaiis will amply pay For any damage done,

It's not so common, that two-cents of 1851.

I once bought ten from 'Birdcage' Ben

For ten 'bob' - and some lies-

Which he suspects, else why should he Those Stamps now advertise?

The thirteen-cents is common here, And I have picked up some

With good, full margins, and-what's much

More hard to get-full gum. 
With copies, tho', as fine as mine

One very rarely meets,

They're mostly poor, the copies seen

On most Exchange-Club sheets."

"What Clubs do you refer to, pray?"

I asked Paul, casual like.

Munchausen shirked the question and

A new lie-vein did strike;

He thought to take me down, but when

He said, "You've noticed, lad,

How few thirteens have got full gum?"

I said, of course I had!

"Their source revealed was in the song

The Queen to-night did sing,

(The Philatelic Privateer

Did not know everything!)

Now, re the so-called rarity

Of stamps of far Hawaii,

Is not my theory near the truth?"

Said I, "It's far away!"

"British Guiana's two-cent rose

Of 1850's good

Without gum, but to get with gum-

By gum! I wish I could!

But, till the Fur-Coat's mine, in Stamps

I take small interest.

Besides, Ben's sales have proved to me

How common are the best. 
You can have my Guianas, Will (Could I believe my ears?);

Of such uncertain countries I

Have certain doubts and fears."

"What price Mauritius P.O., Paul ?"

(I meant to "pull his ear")

"Well, that's a Stamp which I admit's

A scarce Stamp, even here."

"A scarce! Does there exist at all

A single Stamp that's rare?"

Paul slowly rubbed his chin and said,

"Of most there's some to spare."

One of his many "wrinkles" then

He gave me, with a wink,

“There's more or less of certain Stamps

Than certain people think!

As for Mauritius - take, let's say,

The famous P.O. pair,

It's possible that you to-night

May pick them up-don't stare

Like that! But if they're here, they're yours,

You've backed me up so well.

My only 'want' is that Fur-Coat-

The rest's a bagatelle."

"My fingers burn, if but to touch

Those treasures, Paul, so rare!"

"If you'd not burn your fingers, Will,

Pray exercise more care! 
Until one question settled quite Has been concerning them-

The number that was printed-I

Won't touch the P.O.M.!"

"Then let me touch 'em, do!" said I,

" And I'll put on no 'side,'

I like 'uncertain countries,' for

I've got no beastly pride!"

"Well, if you will-see that old Jew,

With those books on a tray?-

He looks a likely party." To

The Jew I made my way.

"I'd iike to see your Stamp-books, friend."

'The friend looked half ashamed,

"Vat sort o' Shtamp you vant, ma frent?"

My want I boldly named-

"The Post Office Mauritius, please,

The pair-the blue and red."

Old graybeard rather puzzled looked,

And vaguely shook his head.

Then softly spoke shy Shylock's son,

"Ah, yeth, zat Shtamp I know.

Ma frent, I only cot a few,

Ma shtock's run radher low,

Ve don't get zem in quandidies

As vunce ve used to do.

Put hav' a look at zis ole book

An' you ma' findt a few." 



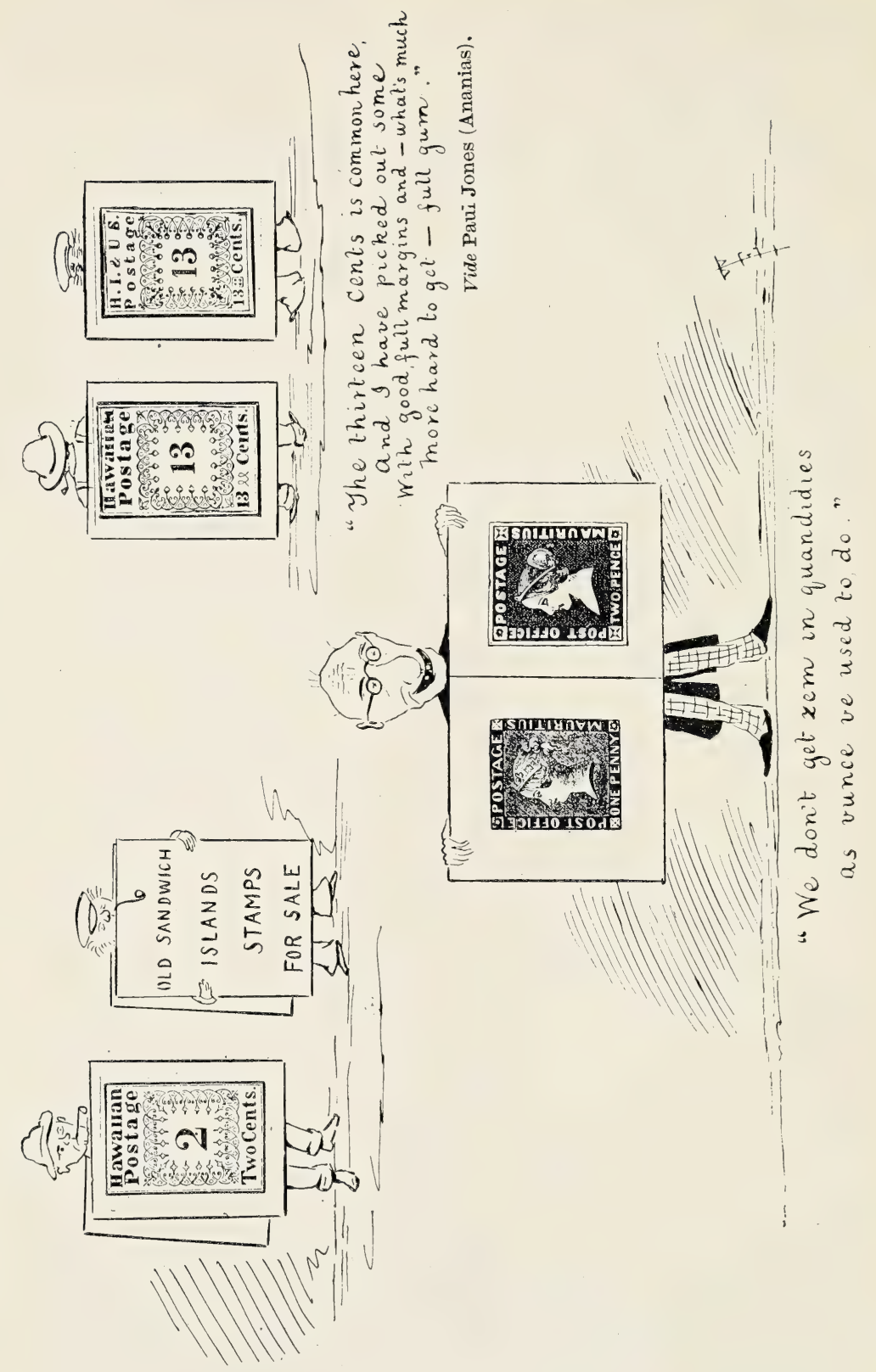


I looked, and on the first page lay,

In beauty smiling there,

A couple of each value, each

$A$ mint unsevered pair!

"Ma price for each Shtamp's half-a-crown, Shum dealush sharges more."

I owned they did, paid my "half-quid," And took the priceless four.

Old Isaacs looked so pleased that when We'd left him, I confess,

I asked Paul (human nature's such), "Would he have taken less?"

"You ought to twig by this time, Will, Which way a twig is bent, And know the antiquated dodge Of anti-Gentile gent."

What cared I now for gibe or sneer?

I'd tons of "chaff" not mind,

For in the Stamp-world's history I

Had found the finest " find."

Should rival Phils my good luck know,

I'd take it out of them.

They'd green with envy turn who saw

Will Wylie's P.O.M.

Will Wylie, The Mauritius King!

No King such Stamps has seen.

To these you've naught akin, Kintore

Give them their due, Duveen! 
Tapling's and Herr Ferrary's gems-

O'er such my find prevails,

And Avery's would not carry weight

Were mine thrown in the scales!

* * * * * * *

I'd reached ambition's pinnacle, And from its giddy height

With pity I'd look down upon

Each Stamp-collecting wight.

Of the wide Philatelic World

Will Wylie would be King.

Would "bargain-hunters" mad become

The while I'd gaily sing :-

\section{P.O.M.}

Don't talk of your bargains to me, sir!

Don't mention your wonderful " finds" !

It grieves me to say that some have a way

Of finding such things-in their minds !

My P.O. Mauritius make all avaricious,

And some most malicious when they

Learn just what I bid for, and got " half a quid " for ;

If asked where I got 'em I say :- 
Pom-pom, tra-la-la,

Pom-pom, tra-la-la,

I'll locate you the source of each "gem,"

'Twas the Boar's Head, I mean,

And old Big Ben between,

Where I picked up the rare P.O.M.

I'm shadowed by Phils when I walk out,

Those far-seeing gents, tho', are blind

Who fancy, no doubt, some day they'll find out

The "Stamp-beat" where I found my "find."

It's simply delicious to think my Mauritius

Make staid men capricious and sly,

They make me big offers to tell 'em, but proffers

Of bribes I decline, and reply :-

Pom-pom, tra-la-la,

Pom-pom, tra-la-la,

You shall learn where I picked up each gem.

It's no yarn that I pitch,

I unearthed in a "Ditch"

The two pairs of rare P.O.M.

* $\quad * \quad * \quad * \quad * \quad *$

'Twas Paul who broke the thread of my

Stamp-jubilation song,

Else I'd ideas enough to spin

It out a full yard long. 
It might have bored you, reader, but

Not more so, that is clear,

Than you've been bored by Paul, the "tall,"

Tale-pitching Privateer.

"Wake up, man, let us clear them out

Of all you wish to clear!"

Then set to work, and with a will,

Will and the Privateer.

To mention half the Stamps we bought

Would fill a thickish book,

At length we found a mild Hindu,

The last wight left to " rook."

He'd " errors," all unchronicled,

He showed a varied "lot"

Of Bamra, Chamba, Holkar, Dhar,

Kashmir, and Faridkot.

He guaranteed each one, and said,

Direct he'd got them all

From Fakir Fakem Gumpap Sham

(The "faker" of Nepaul).

We took them "on their merits," and

The Hindu paid a crown,

Before the "sahibs" he salaamed low

(Whilst, p'r'aps, he took us down).

Said Jones, "Well, these 'discoveries"

The Major hard will hit;

The Native States are, after all,

Not 'written up' a bit." 
“ Don't stultify the labours of The M.J.'s genial Ed.

I hope you'll keep this to yourself, Now promise, Paul," I said.

"For heaven's sake!" then Paul replied, " Don't carry on so, don't!

I don't know much of heaven, but For Evans' sake I won't!

These ' errors' are not listed, tho', Let's see-I'll bet, not one!

Here, hallo! where's my Catalogue, The one I swore you on?

But, there, it's but a trivial loss." This loss, tho', let me state, East London's safety jeopardised! But why anticipate?

Another strange thing happened then, (This admonition's pat, Lest you, dear reader, doze, altho' I'd marvel not at that!)

A pedlar cried, "Gents, look at these! This lot the biscuit takes! (His "rhyme" was on a par with Paul's) What price these woodblock Capes?"

Then something prompted me to ask ('Twas bad taste, you'll agree) :

"Have I the ghost, Paul, of a chance A real, live ghost to see?" 
"Your morbid wish is vain," hissed Paul,

"You take it straight from me,

You will not have the phantom of

An opportunity!

Let's place our plunder in the cab,

Here, Will, you take the sacks!

I'll help to carry something, too,

Give me the R.V. Blacks!

Tho' young, your night-thoughts are not nice,

I can't now look upon

Those gruesome" - Paul could ne'er rhyme Capes,

So I put in, "Lead on!"

I cursed him, sotto voce, then,

For might I not have found

Another "nameless shade" of Cape,

Had I but looked around?

Then safe within the wondrous cab

Our treasure trove we stowed,

Black Bess had never drawn before

So rich and rare a load.

Were Earée in this eerie place

What might-might not find he?

What if the flow'rs we gathered proved

His own wild kind to be!

No! such a thought were terrible,

We'd sown prolific seeds,

'Twas ours to reap a harvest rare,

But not of "Album Weeds." 
"And now, my boy, let's have a drink!

We've called each other ass,

And split a lance or two, so now

Let's go and split a Bass!"

“They're closed!"- “ Not quite, the Pedlars' Arms

Has got an all-night bar,

A buxom lass presides there, Will."

"All right, Paul, right you are!"

"You've got an eve for beauty, eh ?"

"Yes, Paul, and only one,

If t'other closed is for to-night

I'll see but half the fun!"

"The Hebe at the bar there is

The finest girl, I vow,

That you e'er cast an eye on, lad."

"My eye feels better now."

"Her eyes (why did Paul harp on eyes-

Just then, my tender spot?)

Are like-have you your colour chart

With you?" I said I'd not.

“They're violet, blue, or green-but I

Your colour-knowledge lack."

I muttered, “ I'm at present an

Authority on black." 


\section{XXII.}

\section{A Maștenfful Monopolișt.}

We two knights-errant then sent out

To those outside the bar

A hogshead-cask of strong " Old ale,"-

(How free knights-errant are !)

To wet the beaks of birds we'd plucked.

Thought I-in many ways

What splendid bandits Paul and I

Had made in olden days.

But Paul's idea of beauty, tho',

I own is hardly mine,

The Hebe whom he'd spoken of

Was nothing more than "fine."

The Lily's-Philatelic Flo's-

Such beauty ne'er I'd pass,

Nor Pauline's-(yet to think I'd lost

The three in one, alas!).

The big boss of the Pedlars' Arms

Was also in the bar,

And on familiar terms with Paul

(Whose "finds" the queerest are). 
Said Jones to me, "Tho' Boniface

The pedlars patronise,

I've won him over, and The Cause

He'll help-should cause arise.

'Tough' Tucker of the Pedlars' Arms

A tough 'un is, 'tis true ;

His pork-pies, too, without a doubt,

Of toughness claim their due.

The Hebrew renegades, I'm told,

All patronise those pies,

Tho' knowing well beneath their crust

The meat forbidden lies!

We'll wait here now for Birdcage Ben.

I wonder what he's at?

(We little dreamed that that sly dog

Had pounced on Jones's cat!)

Now, Will, as I your reprimand

Took well, you take from me

My admonition to preserve

The greatest secrecy!

I'll bind you by no second oath.

(Well, now, I'd keep the first!)

But point out why this new Stamp-mart

In secret must be 'nursed.'

This visit will not be our last.

(Alas! too sure was he.)

But, mark the awful risks that would

Attend publicity! 
You can, I trust, a secret keep,

I'll give you, Will, your due.

Just picture now, were this place known,

The scene that might ensue!

'Think, where would you and I come in

If here should make a raid

Our rivals, the Collectors, and

Our natural foes-The Trade?

Of course, with both the dealers and

Collector-dealers, too

(Who know too much), my talk about

Stamp-licences won't do.

But these poor eastern ' simples' hold

No dealer's greedy views,

They've no idea of values here--

For most of them are Jews!"

"Yet, Paul, 'tis playing low the game,

In the world's eye, I fear."

"All my eye and Betty Martin!"

Then sneered the Privateer.

I'd strive no more, for I'd to this

Conclusion come, at length,-

To keep Paul in the straight path was

A task beyond my strength.

"The prices here would, wily Will, As well you understand,

A revolution cause at least

In prices in the Strand. 
(I hope the revolution here To-night will not spread far.

'Twere bad if it should spread beyond This side of Temple Bar.)

This spot's my home. I've now three homes, This is the best of them."

(Hear this, fair Devon's “ Woodblock-House," Hear this, sweet "Richmond Gem.")

"But, once 'twere known, the 'cute Stamp crowd In thousands here would fly.

To see that day, who'd wish to live?"

I said, "I'd sooner die."

"Just think, now (for you sometimes think, Despite your thoughtless talk),

What millions to this place would come.

No distance great would baulk

Their bargain-lust. By road or rail

They'd ride, or drive, or walk."

(" On bonny 'Bless Bess' you could bolt, And do "the ride to York." ")

"From Glasgow, Manchester, and Leeds, From Brighton, Bristol, 'Brum,'

Would special trains with 'Specialists,'

All packed like sardines, come. (The L.C. and S.W.R.

And such lines count not here, For ere their passengers arrived

We'd all have time to 'clear.') 
What of the Irish? (Don't say 'Scotch,' It always makes you talk.)

They'd double lines of mail-boats run

From Dublin, Belfast, Cork.

The Emerald Isle's more keen than 'green'

Regarding Stamps, you'll note,

A fact that Lil knew when she played

To win the Irish vote."

"And what about the Auctioneers?"

E'en at the name Paul cursed.

"Before they knock a ' lot' down here

I'd knock the lot down first."

His wretched punning habit, then

(Please don't think I'm to blame),

Led Paul to make improper puns

On many a proper name.

Pre-Ventom coming here's the plan,

While Stamps can be Hadlow,

For Martin there's no Ray of hope,

No Bull his horns shall show.

I'd drop his hammer on the head

Of each who this way comes.

I'll have no Plumridge probing here

To pick out all the 'plums.'

I object in Puttick-ular

To Simpson coming here;

We'll have no Edwards eastwards," said

The punning Privateer. 
“ All Bulls and Buhls, and 'bears,' I bar,

I bar each auctioneer.

Such birds of prey, by night or day,

Will this night-hawk shun here.

No matter where Glendining is,

He shan't come dining here.

This fairy Stamp-glen dining in

I'll have no auctioneer.

I've named a few, but that will do,

They shan't ' do' me, no fear!

They're all a set of villains!" said

The libellous Privateer.

“Would M.P.'s take the matter up, And some be 'taken down,'

For putting questions in the House

That would amuse the town.

Some ignoramus p'r'aps would rise, And, in complacent tones,

Betray himself to a full House With 'Who is this Paul Jones?'

Then, 'I've no information ' would Some Minister reply,

'To lay upon the Table' (where

So oft they lay a lie!)

Henniker Heaton, rising then,

His aid would volunteer,

- This Paul Jones is The Famous

Philatelic Privateer!', 
"And then there'd be ' loud laughter,' Paul "To laugh I did begin.

"Be serious, Wylie, just for once-

Not ever on the grin.

Would Heaton add (and this ad. would

Rouse deafening applause)-

'The Jones named is the only one

Who's done aught for The Cause!"

"Indeed! What price Will Wylie's name-

Would that evoke no cheer?"

"Your name need not be dragged in," said

The paltry Privateer.

"The strategist who plans should take The honours, I suppose-

A mere civilian cannot-" "Hold!"

Cried I. Then up I rose.

“Bah! 'Mere civilian'! If you don't That curst term leave alone,

I'll go for you and pit my ten

Against your twenty stone!

To us-We, of the Fourth Estate-

Your gratitude is due:

Without our ' fine descriptive lines'

Who'd hear of such as you?"

“Tut, tut, Sir Spitfire, let us not

Our dirty linen wash

The presence of the foe in." "Yes,

It's dirty, Paul, by gosh! 
But if my name's not mentioned in

These Parliamentary sports

By you, then I shall send in sharp

My own and full reports.

Then I'd make dark disclosures, Paul,

'Twould suit the papers prime-

' Great Philatelic Scandal,' or

"A Guardsman's Awful Crime.',

"Such references," Paul coldly said,

"Betray your want of tact.

Remember, I should swear you were

Accessory 'fore the fact!

Would Heaton's speech 'bring down the House'-

Down here, too, to a man,

And Ocean-Penny-Postage $\mathrm{H}$.

Himself might lead the van;

Bill's Stamps would at a premium be.

(Paul meant, of course, the 'Boer.')

M.P.'s are interested in

The 'issues' of the war.

Then here's to Heaton, champion of

The Stamp-Fiends in the House.

His motto's always, 'Now's your time!

For Heaton's full of nous.

I wish, too (tho' I wish not to

Build castles in the air),

That M. P. Castle were M.P.,

They'd make a lovely ' pair.' 
To buy us out they'd thro' the House,

No doubt, soon rush a bill.

('In rushing me down here to-night

I think you've rushed a Bill!')

'They'd transfer Tapling's treasures here,

The B.M. Trustees, eh?

Relieved of their white elephant,

Would naught in protest say!

The Lords, of course, would not be slow

Down here to take a peep;

At least, on that occasion they'd

Forget to yawn or sleep.

Would their long latent energies

Our wondrous ' find' arouse,

An upper tendency in price

Would rouse the Upper House.

The Bishops, too, would like to pick

Some Philatelic plums-

Then good-bye to our pickings, tho'

One Bishop only comes!

My Lords Ecclesiastical

Would fly here to a man,

And 'Devil take the hindmost!' as

Each portly Bishop ran."

* $\quad * \quad * \quad * \quad * \quad *$


"You'll let each Stamp-scribe come here, Paul ? Draw no hard line and fast

(I flattered Paul). By Nature you

Were in the Stamp-mould cast."

"That's true," said Paul; " the world will say,

'Let Nature's work none mar,

For, Natura lo fece, et

Poi ruppa la stampa.'

If Hull comes here you'll soon a ship

Without a rudder see.

And Gordon Smith, too, will be done

As brown as Smith can be.

Our haul of U.S. Stamps shall grace

Our Hall of Tammany,

Nor care I if we've any tiff

With any Tiffany!

To Davy Jones's locker I

Will Gilbert Lockyer send,

With Gilbert Harrison (a joke

Of true Gilbertian blend).

They'd need a doctor, tho', if they

Should Doctor Viner bring,

For such a Stamp-diviner I

Would be prepared to swing!

And should Napier down here appear,

To make a (sea-dog's) cat.

Of Stamps, till now, uncatalogued-

D'you think that I'll stand that? 
I'm not asleep. He'll find that I'm

As wide-awake as he,

And N. won't save his bacon if

He brings here E. D. B.

* $\quad$ * $\quad$ * $\quad$ * $\quad * \quad$ *

Our cousins 'cross the 'Herrin' Pond.'

Would they in patience wait

Whilst folks here snapped the bargains up,

Then cross 'the pond' too late?

Too late the precious ' gems' to buy,

Their luck (and ours) they'd damn.

We've trouble had with ' Uncle Paul' -

Have none with Uncle Sam!

With cargoes big of Yankees cute,

All fired with lust of gain,

Would swift 'Atlantic greyhounds' soon

Be coursing o'er the main.

Of millionaire-collectors each

A full saloon would bring.

You'd be no 'pot' amongst that lot,

And I no longer king.

Would complications, rise between

This country and the States,

And war result, for over Stamps

No nation arbitrates, 
Their wealth would 'square' the circle of These Pedlars. For they'd fling

Their dollars free, and make this square

The centre of a 'ring.'

They won't find here 'the open door,'

Not if they bust the lock-

For you and I can make a bolt

(With 'preference shares in stock').

They'll pull long faces, and, you bet,

A free fight's sure with such,

And then-well, their face values won't

Be valued very much.

Those Yankee philatelic cards

Our sense of honour lack.

The knaves may sport their diamonds, but

Our clubs will 'cut' the pack.

I like to call a spade a spade-

A dig I think they'll feel.

They'll have to play their cards well if

With me they have to deal."

“Yet, Paul, our namesake's guests, ere long, The H.A.C. may be,

When Boston's, Massachusetts' Ancient

Corps we go to see.

What if I your kind sentiments

Convey to 'Uncle Sam'?

You would not care for that!" Said Paul,

"I would not care a d _- ! 
The Monroe doctrine here applied

With good results might be.

For ' You may look but mustn't touch '

The creed's for you and me.

Yet no dog-in-the-manger plan

Shall mark our policy,

But share and share alike-tho' none

Shall share with you and me!

Our ships and shipping trade they've bought.

They shall not buy our Stamps,

Tho' fleets of six-day liners or

Slow-going 'ocean tramps'

Be chartered, millionaires to bring,

Our private ring to bust.

We'll form a Wylie-Jones Combine

To fight their Morgan Trust.

See here the Arms that I've designed.

What think you of our 'coat'?

The Fur-Coat figures on the field,

The Cape on which I dote.

' The Boer,' The Boar's Head, Grim and Bess-

You'll note, I none forget.

You call this neat?" "I do," said I,

"And gaudy, too, you bet.

You don't believe, Paul, all you hear ;

You can't believe, I know.

Each canard re The Cunard

(Some e'en doubt the $P$. and $O$.). 
We'll neither drop our Anchor, lad,

Nor cut our Cable yet.

I don't believe, tho' things look black,

That our White Star is set."

Paul rose and paced the bar, as might

A tiger pace its cage.

The thought of competition roused

The Stamp-Fiend's awful rage.

All likely rivals he denounced

The while dire threats he hurled

At one and all. In short, he gave

A challenge to the world.

"No matter," cried the Privateer

(He did look brave and bold),

“This Philatelic Klondike's ours,

And what we've got we'll hold.

Our Admiralty may be asleep,

But, tho' I stand alone

In stemming this invasion-well-

I'll do it on my own!

My armoured yacht, The Mulready,

Is ready for the fray.

Her crew are all Philatelists

(The entire crew, I say).

At forty knots an hour, with

The fastest craft she'll cope.

She's sailing with sealed orders in

Her namesake's envelope. 
And when she meets the Yankee ships

Her shot their sides will bore

With compound perforations, such

As no shot made before.

Great Scot! Her guns are Terrible,

Her gunners' practice fine;

They hit below the water-mark-

I mean the water-line.

Paul Jones the First helped Uncle Sam ;

Paul Number Two atones

For his misdeeds. Old John Bull now

Counts on the only Jones.

Our champions of Philately

Need for The Cause not fear

Whilst lives the Second, up-to-date,

Paul Jones the Privateer."

I knew by Paul's appalling words

That for Philately,

As bravely now he fought on land,

So would he fight on sea.

He stood supreme, the champion of

Our interests alone-

Of mine and yours, dear reader-not

Forgetting quite his own. 


\section{XXIII.}

\section{IHGe phanfom.}

Upon the scene came "Birdcage" Ben, Who took with us a drink.

Was rum, and raw, his " tonic," which A " tonic" rum you'll think.

Said Ben, "This book I picked up has

Your name inside-Paul Jones.

Of telling you I've read it thro'

I'll make, my friend, no bones."

Just think! Paul's missing Catalogue

Had read been by the Jew!

The latter's words now proved indeed

That far too much he knew.

“'Thro' reading this 'Part I.' my eyes

Have opened been to-night.

How blind we've been! But this to me

Of money's worth a sight!

My time I've spent since I left you

In reading this Stamp-guide.

I'd no idea that such a book

Was published, but have tried 
To master its contents, and find

That you have paid us-zounds !-

In pence for certain Stamps that in

This book are priced in pounds."

"Your knowledge comes too late, my friend.

It does not me surprise

That, after the event, can men

Like you be wondrous wise.

Allow me, sir, to tell you this

(Paul's tongue was made to sting) -

A little knowledge is, to such

As you, a dangerous thing!'

“To such as me!" ('Twas Shylock's turn.)

"How many a Guardsman, pray,

Had, but for me, his precious debts

Of honour failed to pay?

In my veins flows Mendoza's blood;

No foe did I e'er fear.

And, come what may, I thus defy

Paul Jones 'The Privateer!"

His fur-lined gauntlet off he snatched

And at Paul's feet he threw,

When changed the sapphire ring he wore

From pale to deepest blue!

He started. "By the spirit of

My fathers well I know

That I have drunk a spirit in

The presence of a foe!" 
Punctilious Paul the gauntlet on

His sword's point forth did hold.

" I'dl fight you for the Fur-Coat, Ben, Against the Stamps you've sold.'

Ben then his coat a pole hooked on That stood beside the bar :

Paul flung his cloak across a bench : Will waited for the spar.

What would have been the finest fight The boxing world had known

Was not to be. (The loss to me, As scribe, I'll e'er bemoan.)

The chatter round the cask of ale Outside became a cry

Of terror, and, the cause to learn, We three outside did fly.

And then a strange thing happened-'twas

The strangest thing of all

The strange, weird things that happened had:

The bravest 'twould appal.

E'en as I write the very thought

My hand doth cause to shake.

Pause, reader-as I here must pause

A long, deep breath to take.

Q 2 
A cold air swept the courtyard thro'

('Twas cold even for May-

Unlucky month for me, for Paul

Its most unlucky day).

Each mortal present shivered as

Do mortals with ague.

In fear the bar cat arched its back,

And mewed an awe-struck mew.

Then, lo! a phosphorescent light

The Stamp-sale's site illumined-

A light that slowly formed, and then

A human shape assumed-

The form of one I'd heard of, tho'

In life I'd ne'er met him.

This whispered warning passed around:

"The ghost of Pedlar Jim!"

"It" spoke: "I'm free to walk upon

The anniversary

Of my cruel death-a permit I

Hold from the L.C.C.

I died the second day of May."

"This," whispered Paul, "'s the First."

"It was," said I, " but midnight's past."

Paul groaned, "O luck accursed!"

Again spoke in sepulchral tones

The wrathful wraith of Jim,

Whilst hung the spell-bound pedlars 'pon

The words that fell from him. 



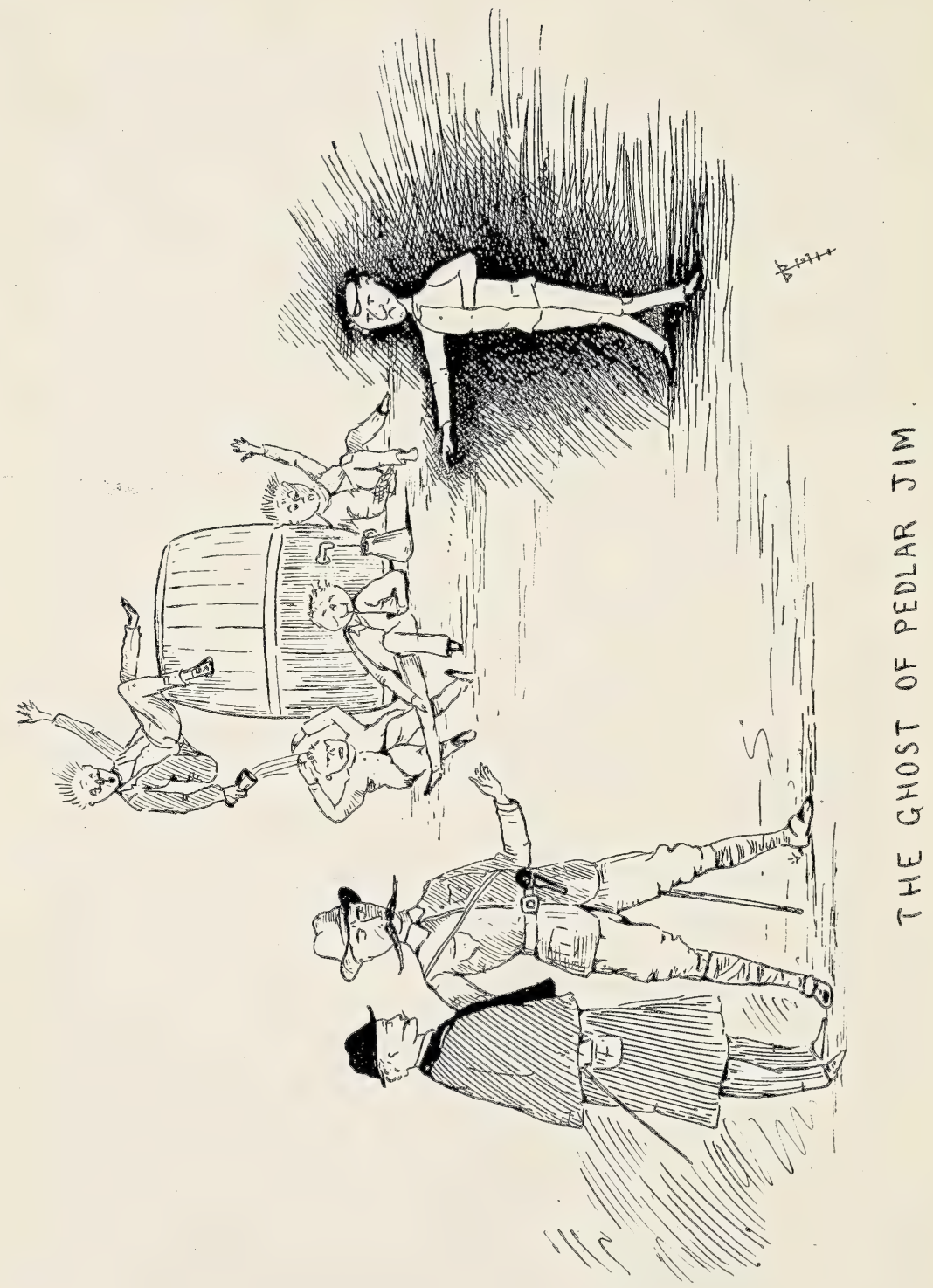


"Who murdered me is in your midst.

Don't let the wretch escape

Who took a precious life to get

A penny woodblock Cape!"

I glanced at Paul. The ghost, 'twould seem,

Had some impression made.

His face had turned a livid green

(Of green the rarest shade).

Paul erst had chaffed those pedlars poor

When asked for " lots" to bid.

He'd ask, "Do you see any green?"

- And now, by Jove, they did!

Then in an instant rallied Paul.

The rare green shade had fled

From out his cheeks, which gained once more

Their common, healthy red.

But few his change of colour saw,

And they'd guess only part

Of what it meant-for no one there

Possessed a colour-chart.

The Phantom's thin forefinger now

Was pointed straight at Paul.

"There stands the man who on this spot

A corpse caused me to fall!

'Tis time that May the second's crime__-"

"The truth is, it's a lie!"

Paul shouted. " Here is evidence

To prove an alibi. 
The second day of that same May (It matters not which year)

I with Judge Philbrick dined, and he Then signed the form I've here.

Read that, Big Ben-an alibi.

The Judge's name's writ large ;

For his judicial mind foresaw

This base, yet baseless, charge."

"This seems correct," said Ben. The Ghost

In plaintive tones " appealed":

" $H e$ 'kids' you, as he 'kidded' me;

Then soon, Ben, you'll be killed.

He'd knock you out of time, Big Ben;

Your 'dial' to smash he'd like.

Don't stay, but use your hands quick, Ben.

Big Ben, why don't you strike?

Look to the coat-the gray Fur-Coat!

You'll in its lining find

Stamps that are worth a million pounds.

Their visit here's a blind.

He and his henchman (this for me)

Have sworn an awful oath

To have the coat. Then strike in time!

Spare not, but slay them both!"

* $\quad$ * $\quad * \quad$ * $\quad$ *


The Pedlars' Arms was closing now:

Its " boss" foresaw a row.

The sound of bolts caught Jones's ear.

" It's never, lad, or now!"

$\mathrm{He}$ dashed in, caught the pole on which

The Fur-Coat hung, then made

A dash outside to reach the cab ;

But Ben his passage stayed.

Big Ben, ex-pugilist and ex-

Dragoon, sent in his left.

Paul ducked; then fair between the eyes

Caught Ben with " counter" swift.

Down went the giant like a stone.

A yell the blow did greet.

Paul held the Coat: I did my best

To cover his retreat.

I struck (I ne'er in all my life

So much enjoyed a fight)

First with my right, then with my left;

I struck out left and right.

And dear old Oxford mem'ries rose

Whilst knocking pedlars down.

Once more I played that glorious game-

The game of "town and gown."

Barred now our passage to the cab

A wall of clubs and knives.

Said Paul, "Tho' cheap they sell their Stamps,

We'll dearly sell our lives. 
Back to the market's centre-quick !

Between us, lad, we'll hold

The centre walk - the Coat's our flag.

They're coming, Will; be bold!

Draw !" and out flashed Paul's sabre keen And my Toledo blade.

" Reserve your 'Colt,' Will, for the last, And use your cloak as guard.

Big Ben's placed hors de combat, and

I funk no front attack.

That ghost behind, tho', makes me feel Cold water down my back.

We'll give the beggars first a chance."

Here Paul produced a scroll,

Which he, as calmly as a judge,

Proceeded to unroll.

As proof of his judicial mind,

He first read out aloud

The first clause of the Riot Act,

Then fired upon the crowd.

That was the signal for a scene

As ne'er before I'd seen.

Paul only hit a couple; but

It seemed to rouse their spleen.

Tho' educated nowadays,

And better fed and housed,

An East End mob's a savage mob-

So easily aroused! 
Around us in an instant swarmed

A crowd, dense and compact.

Paul hissed, "We've got a free hand since

I've read the Riot Act.

We've done all that the law prescribes,

And few our course can blame.

I. wish, tho', that confounded ghost

Would not keep shouting 'Shame!'

The olive-branch we offered to

The meaner brotherhood

Of Stamps; but they the sword have drawn, As cut-throats ever would.

We're men of honour, pledged to break

This Stamp 'ring' so accursed.

Tho' this night's work the Empire wrecks,

Philately comes first!" 


\section{XXIV.}

\section{All for Thhe Cauşe.}

Surrounded by a wild mob stood

The dauntless Stamp-Fiends Two-

The finest Household swordsman, Paul,

Whilst I good " play" could do

The rapier with. My "pretty point".

Full many a " hit" had made

In many a fencing-school, where I

Was called "The Lightning Blade."

We two the centre gangway held,

And step by step made way.

Paul's sweeping cuts, my deadly thrusts,

The foe kept well at bay.

" 'Tis time that signal-shot of mine

Brought aid," said Paul. And then,

With fearful curse, and sabre armed,

Leapt to the front Big Ben.

Had Guardsman then and ex-dragoon

A worthy foe each found.

Ben served had in "The Royals," and

A swordsman was renowned. 
Clash! and their blades met, sending sparks

In brilliant shower around.

The pedlars watched the combat now

In silence and profound.

Down in my estimation went

Big Ben, for once and all,

For hinting in low language that

He'd mincemeat make of Paul.

The braggart's vulgar threat proclaimed

The lowest type of Jew.

"I'll soon a Cambridge sausage make

Of this big "Oxford Blue'!"

A cut from Paul nigh broke Ben's guard;

But Ben gave straight and smart

The " point," and caught the Privateer-

O dear! - just o'er the heart.

Paul reeled, and I-I closed my eyes,

Then heard him cry, "No fear!

Your thrust was true, but, 'Birdcage Ben,'

I wear the snuff-box here!"

"My snuff-box!" groaned the tell-tale ghost, Who still "walked" in the rear.

"He cannot die who holds the box!"

Again Paul cried, "No fear!"

Jones made a thrust ; Ben's parry failed:

He fell with scarce a groan.

"Twas finished. "Next year," moaned the ghost,

"I shall not ' walk', alone," 
Maddened the mob their leader's fall.

Then for a charge they formed,

As thro' the rear gate of the Square

Fresh pedlar-levies swarmed.

Then, bursting thro' the mob's massed ranks,

A welcome form was seen.

A cry rose from the surging crowd:

“Th' Boar o' Bef'nal Green!"

Came Philpot and "The Baron," too,

Supporting Bludgeon well

With many a blow from ready fists.

By George! they used them well.

Then Tucker, plus a fowling-piece

(Tho' he'd his licence lose),

Came forth to fight, and-sportsman-like-

The weaker side to choose.

They rallied round the Fur-Coat "flag,"

The dauntless fighting six.

“ Bill's bodyguard should soon," said Paul,

" Release us from this fix."

“They ain't enuf," said Bill. "This scum's

Bin callin' aht reserves

As far as Saffron 'Ill. To-night's

Upset the'r furrin' nerves.'

Paul formed us up the while our foes

Council of war did hold.

The ghost was president, for he'd

Been " under fire," I'm told. 
“ The perlice can't touch us 'ere," said Bill,

"'Cos this is private grahnd,

An' Toosday night's the'r orf night, so

They won't be prahlin' rahnd."

"Look, Bill!" Upon the neighbouring walls

Long rows of cats I'd seen,

Who sat in watchful attitude.

"What does their presence mean?"

Bill Bludgeon soon the mystery solved.

"It strikes yer rayther rum,

But Grim 'as brought that lot, acos'

'E knows 'is chance is cum."

"What are those big bird's fluttering round?"

The sage strange words did speak:

“Them's crows from 'Ackney Marshes, lad, An' rooks from Barkin' Creek.

They knows ther's goin' to be a fight :

Them wultures ov th' East

Can scent th' bleed for miles arhand.

To-night they'll 'ave a feast !

This 'ere 'll be th' biggis' scrap

As ever wot I seed,

Wiv' scores o' pedlars' carcasses

To giv' th' birds a feed."

Well, come what might, I'd play my part,

And in the thick of strife:

I'd lost the only girl I loved-

I'd lose my only life. 
"It's time as 'ah me boys arrove,

I'll jus' pop.aht an' see.

They ought ter leave th' beer for ouce

W'en bodyguardin' me.

But, 'owsumdever, I'll slip aht,

By yer leaf, kernel. Oh,

Don't fret for me; I knows th' ropes.

I'm back in 'arf a mo'.

* $\quad$ * $\quad * \quad$ * $\quad * \quad$ *

Th'Boar's 'Ead lot's a-comin' on,

A-singin' ' 'Old th' Fort.'

At fust they went an' lorst the'r way."

Paul growled, "Just what I thought.

'That's English, tho', if just to show

Why we get taken down.

We lack, it seems, a knowledge of

The country-and the town.'

“'They jus' wos goin' ter cheese it, w'en

They meets a frien'ly scout---

'Dutch Dan,' wot's from th' Transwale, knows

These parts." Said Paul, "No doubt."

“ Th' pick ov orl ahr scrappin' lads

Is marchin' ter yer aid-

'Ark! - that's the fightin' woar-cry ov

Th'Bef'nal Green Brigade!"

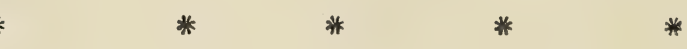


Then burst upon the battle-scene

The cream of London roughs.

The dreaded Sydney "larrikins,"

The boasted New York " toughs"

Are children, as compared with these,

Whose bullet-heads and hard

Defy the "peeler's" truncheon-blow-

Bill Bludgeon's Bodyguard.

“This looks a raw crowd," Paul remarked.

"In check the foe hold, Will,

The while I put these ruffians thro'

Some elementary drill."

" Just like us, always unprepared,"

Sneered I. “It's English quite

To think of drilling raw recruits

When half-way thro' the fight!

Now, why not let Bill lead them, Paul?

They'd follow him to___ " "Well,

You're right, p'r'aps," said The Privateer.

"Set 'em to work now, Bill!

But mind you first attack their flanks."

" That ain't no good," Bill said.

"The only way to kill' 'em is

To 'it 'em on th' 'ead!

To-night's th' best day's work I dun',

Me prahdist moment too.

Nah up, blaggards, an' at 'em-like

We dun at Waterloo!" 
Bill's words prophetic true had come, And some would " get it stiff,"

For loud rang out his rallying cry" Rimimbir Lydy Smiff!"

Bill's charge superb roused jealousy (Professional) in Paul.

"That's not a regulation charge; Their fron's not dressed at all."

Then, soldier-like: "I'll own that Bill's The coolest hand I've seen."

(I'm told that they think nothing of Such fights round Bethnal Green.)

Once more the foreign element

Did levies strong r'-inforce.

Bill's bodyguard enveloped were-

But still fought on, of course.

Then Paul Our Goddess did invoke

To save her lost Brigade;

When, lo! assistance was at hand-

But 'twas not human aid!

* $\quad * \quad$ * $\quad * \quad *$

Rose high above the battle's din

('Twas heard, they say, for miles)

The war-cry of the Houndsditch Toms-

Those terrors of the tiles. 






Our fight renewed an ancient feud.

A pedlar Grim once kicked.

To "wipe it out" Grim led a band

Of fighting "Toms" and picked.

See how they fall upon the foe

And break their serried ranks!

They cut the pedlars' rearguard up,

Then fall upon their flanks.

The shirts they tear from off their backs,

And scalp their luckless heads;

They cut the wretched stragglers off,

And tear them into shreds.

Now on the scene The Pup appeared,

To join the tom-cats' ranks.

Much damage did the "beauty" with

His " playful little pranks."

The British bulldog's dire contempt

For foreigners was shown,

For Pup's bull-headed charge displayed

Great pluck-but pluck alone.

Then from his pocket Bill let loose

The Spider on the foe.

The vicious "vermin's" awful bite

Meant certain death, tho' slow.

Fled Grim's aversion as he saw

Those bitten writhe like worms, And he and $S p i$ fought side by side, Tho' not on speaking terms. 
The Hackney Marshes "vultures" Hew

In clouds the scene above, For Grim a meal providing was

For them - tho' not for love.

Great havoc wrought the first-prize tom

('Tho' he some followers lost).

He'd no respect for persons, for

Grim even scratched The Ghost!

"A sight this for the Gods!" said Paul, His handsome face aglow.

“ Our Goddess ne'er would, well I knew, Betray us to the foe.

This scene is one that should indeed

Make thoughtless scoffers pause, When eyen these dumb creatures fight

In Philatelia's Cause!"

But rallying now, with dire results

The pedlars plied their knives.

They'd many lost, but now, alas!

Lost many cats their lives.

With indignation boiled the kind,

Puss-loving Privateer-

"Tis time that The Society

Sent an inspector here.

These fine irreg'lar cavalry

Indeed have saved the day.

Tho' Grim and Pup both training lack

And throw themselves away, 
They've quite surprised the enemy,

Tho'-pardon my remark-

They quite ignore the tactics we

Rehearse in Regent's Park."

"No doubt your Park manœuvres, Paul,

Would put De Wet to shame.

But yet these wild irregulars

Do get there just the same.

We don't surprise an enemy

Till they've surprised us first.

Such notions as we nurse, I'm sure,

No Wet 'nurse ' ever nursed."

“Because we've used cat-cavalry

The foe, my boy, will ken

Our present want 's the usual want---.

The want of mounted men.

Could I but lead my squadron here,

The 'rags' would get their dues.

To fight this rabble 'tis, indeed,

Hard lines without The Blues!"

" Rot! what's the use of cavalry

In such a cul-de-sac,

When these cross-benches infantry

Alone would dare attack?

My company of 'Honourables'

Would cause this mob to scoot

For Denbigh's Dandies, you'll admit

At least know how to shoot!

R 2 
But this is no reflection, mind,

Upon the 'Oxford Blues.'

'The Blue Guards' fear no blackguards, and

They've naught to gain nor lose.

If they were here they'd show no fear;

But, tho' no man would shirk,

I'm sure that no 'tin-belly' has

A stomach for such work."

"These stands and benches are," said Jones,

"A hindrance, it appears,

But can't be moved without the aid

Of well-trained pioneers."

Then Bill, who'd found an axe or two,

Demolished, with the aid .

Of several "boys," the benches, and

A thorough clearance made.

But yet, maybe, the "Household " god

Knew something, after all.

A Guardsman's special knowledge proved

Of value now to Paul.

To meet a charge our fighting line

$\mathrm{He}$ at the foe did fling;

Then formed a square in échelon,

And saved our centre wing.

Thus science did the object of

Guerilla tactics thwart.

Paul's movement to the notice of

Tacticians will be brought. 
Stood solid Phil our hollow square

Within, our "flag" to hold;

As standard bearer he (too stout

For charging) off was told.

That "flag" to capture swept the foe

Our solid square around

(For Philpot filled the centre, and

No hollow square they found),

Who knelt, the charge received upon

Sword, rapier, gun, or stick,

Who stood supported with short range

Revolver fire, and quick.

" By gad!" said Paul, " the coroners

Will reap a harvest prime :

If here, the 'Linseed Lancers,' too,

Would have a busy time.

Strange that no police are passing by-

Indeed, 'tis passing strange;

They might, tho' Tuesday's their night off,

For overtime arrange."

“I'll jus' slip aht agin," said Bill,

"An 'ave a look arahnd.

Th' p'lice ain't 'eered it yut, but sum'

'Un must 'ave 'eeard th' sahnd

O' firin'. Well, I'll bring yer my

Report at enny corst.

I 'opes this rewolution ain't

A goin' ter be a frorst." 


\section{XXV.}

\section{Reaping the Whinlwoind.}

Once more "The Boer" rejoined our ranks.

An ideal scout was Bill:

He brought us news from many a source

That made our hearts stand still.

Cisten! fireside Philatelists.

You'll learn when Bill's been heard

What dire responsibility

Had somebody incurred.

Bill was to blame, without a doubt;

For (reckless-like his class,

'Who never weigh results) he'd brought

T'hings to a pretty pass.

As Paul, with truth, to me remarked:

"Such men to think ne'er pause

Before they act. If Bill we'll make

A scapegoat-for The Cause."

* * * * * * *


“ Th' risin's spreadin' everyw'eres.

I finks it's bahnd ter frive.

Axceptin' true born Brutishers,

They won't leave nun' alive.

It's that 'ere bloomin' Parlimint

W'ich them 'ere Corn Laws made.

Ther's nuffink like a free fight for

A-knockin' dahn Free Trade.

I reckins as Joe Chambermaid

Will make a fair, clean sweep

Ov furriners, 'cos w'en 'e makes

The'r bed they gits no sleep.

It's spreadin' Inglan' rahnd th' globe

Wot keeps th' world alive,

It's woar wot wakes us up an' makes

Th' Brutish workman frive.

'Arf Lunnun's bin an' riz in arms-

As w'ich they won't lay dahn

Till orl th' corse o' this 'ere rah

Is druv from aht th' tahn.

They've giv' 'em notice fer ter quit, An' orl th' crahd ter clear,

Wot's sendin' up th' price o' bread

An' lowerin' dahn ahr beer.

They've gorn mad dahn Th' Minories.

It's gorn beyont a joke.

They've set a knacker's yard a-fire;

An' ev'ry winder's broke. 
Th' Jews an' Poles is ' up the pole,' An' flyin' fer the'r lifes ;

Dahn Butchers' Row they're all woke up, An' sharpenin' up the'r knifes.

Th' fire-brigade near Spitalfiel's 'As got a dirty job :

Ter break up ov th' great unwashed

They're playin' on th' mob.

Th' p'lice stations is sendin' men

- Wiv' fog'orns dahn th' streets

Ter wake up all th' coppers wot's

A-dossin' on the'r beats.

Th' foorce 'as 'ad a shock like wot

It ain't received fer yeears.

I'm sorry fer the'r donahs, 'cos

It's knocked th' prutty dears.

Ther's many a luvin' nursenuaid's 'eart

Wot's like ter breık tc-night.

Th' cooks is in 'issterricks, too, An' faintin' left an' right."

Then laughed a loud and brutal laugh

The heartless Privateer:

"Such maudlin, sentimental trash

I'll not encourage here.

I will not sacrifice The Cause

To such love-making leagues ;

Of this job I'll not make a hash

With rabbit-pie intrigues." 
“Ole Bef'nal Green's a stirrin' scene ;

It's one bloodfirsty roar.

Reports 'as reached 'em as I'm kilt:

They shahts, 'Awenge Th' Boar!'

An' wot's a werry 'ealfy sign

Agin' them furrin scum :

Th' Brick Lane blokes orl shahts, ' Urray!

Th' rewolution's cum!'”

" A healthy sign indeed," said Paul;

("Things look worse every hour.")

"It's bad noose, tho,", "The Boer" said, " wot

I 'eears abaht Th' Tower.

Ther's bugles soundin' everyw'eres;

'They've stopped 'em playin' cards.

This rah ain't roused th' rozzers, so

They're bringin' aht 'Th' Guards !

They've mustered orl th' Coldcreams, so

I 'eears, in Lemon Street."

For once Paul quailed. "As Guardsman, how

Can I the 'Streamers' meet?

To free East London of its yoke

Seems now an empty dream :

The Coldstreams will be bound to throw

Cold water on our scheme."

“" Th'r orders is 'No quarter!' cos

Th' colonel's werry wexed.

They've sarved 'em blank ball-cartridges

An' orl's got bag'nets fixed. 
Them 'Streamers,' they means mischi'f, an',

Afore they spiles this biz,

Let's finish orf them pedlars nah

W'ile this 'igh feelin's riz.

It's bahnd ter queer ahr pitch if 'ere

Th' sodgers gits a peep.

Th' slops 'as orl bin summonsed, w'ich

It's bin an' sp'iled the'r sleep.

It wears a ser'ous axpect nah-

$O$ ' that ther' ain't a dahbt,

'Cos fings looks werry fishy w'en

They calls th' lobsters aht."

The flow'r of British infantry,

The pink of London Pride

Were on the march. And now, 'twould seem,

Awake the police were-wide.

For such wild night-alarm would rouse

The dead-in proof of which

The tramp of policemen's heavy feet

Resounded down "The Ditch."

And sadly spoke our Leader then-

Our bright and guiding star :

“'Tis sad to think that harmless Stamps

Should lead to civil war.

But Phils 'advanced' can ne'er go back;

This is no time to pause.

Such things are incidental, but

The main thing is-The Cause." 
Lit up the scene of carnage now

A sudden lurid light,

Which shone the dead and dying on.

Great heavens! What a sight!

Whence came the glare? "Tough" Tucker hissed:

"This caps their hellish games!

See what they've done!" And then we saw

The Pedlars' Arms in flames!

"Mark me!" said Paul, " this day goes down To all posterity

As merry May's most famous First,

That saw East London free.

What 'prentice lads once failed to do

We've done, Will, after all;

'Philatelia's Evil May-day'

The First, henceforth, they'll call.

Now for the cab!" Our priceless "flag,"

Borne by the Privateer,

Our rallying point became, and Bill

(Now made a brigadier)

His old Guard remnant formed. Said Paul:

" E'en if too late to fly,

At least we'll show the Stamp World how

Philatelists can die."

If ever men a passage carved

To glory, we're the men.

I can't remember how 'twas done

(So busy " carving" then). 
An avenue the sabre cleared

Of Paul, The Blues' best man,

Who cut down as at Waterloo

Did Shaw the Iifeguardsman.

With what famed fight could our fierce fight

Compare, I cannot tell ;

I've tried to find, but find that I

Can't find a parallel.

I hate exaggeration, but-

What I say now I mean--

The World's Decisive Battles will

In future count Sixteen!

When all but thro', poor Philpot fell,

Came Tucker's dying cries ;

A blow received I on the head

Which brought me to my knees.

"I'm done for, Paul! Fly! Save yourself !

Tell Pauline how I died."

Then lifted in the giant's arms

Was I, and borne outside.

The mare and cab and Stamps were safe

(The Stamps we'd wisely stowed

The cab's false bottom all beneath).

How much Black Bess we owed!

She, by the pants, caught many a foe

(She recognised each Jew).

Swung each to death till out of breath,

Then down the body threw. 






Into the cab Paul lifted me,

The Fur-Coat o'er me flung;

With parting shot, inside he got.

"The Baron" up had sprung

His perch upon. And then I heard

Bill's cheery, loud " Good-night.

Cum dahn agin to-morrer, an'

We'll 'ave anuvver fight."

* $\quad$ * $\quad * \quad$ * $\quad$ *

Away, away flies bonnie Bess, And danger leaves behind.

Alas! a danger dire ahead,

Ere cleared "The Ditch," she'll find.

What means that dark, advancing wall

That nigh our lives had cost?

Massed ranks of "bearskins" bar the road.

“The Coldstreams, Paul! We're lost!"

Too late to fly. Between two fires

Were placed the dauntless three.

That in the rear burned brightly still :

Thus well shown up were we.

We yet might pass. Yet why ourselves

With hope so false deceive?

Down went the Guards' front rank, prepared

Cavalry to receive. 
"Halt!" At the Colonel's stern command "The Baron" sharp drew rein.

Bess reared - nigh on the bayonets' points.

Paul saved us once again :

He flourished high the Riot Act,

Leaned forward, and let fall

Two words, and magic-only two.

"Queen's Messenger!" cried Paul.

Then “Pass, Queen's Messenger. All's well!"

The credulous Colonel cried.

'Twas "Open ranks, and let them thro'!"

The ranks were opened wide,

Then closed. And onwards swept the Guards.

As we "The Ditch" did clear

Rang out above the sound of strife

The Coldstreams' charging cheer.

Saved! But for what? A cry of pain-

And sharp-rose to my lip.

Wounded and weak, once more was I

Within the "Flu'-Fiend's" grip.

A thousand lights before my eyes

With brilliance flashed: then dim

All things around me seemed to grow-

Rose shadowy forms, and grim. 
"'Tis growing dark. Paul, are you there? Give me your hand, old chum."

I felt the dear, familiar grip, And cared not what might come.

"I'm here, old boy, to see you thro,," I faintly heard Paul say.

My head upon his shoulder sank, And then-I swooned away. 


\section{XXVI.}

\section{fiftery the Storm.}

The morning sun had risen high

When, with an aching head,

I woke-to find myself at home-

And found myself in bed.

Well Paul, the good Samaritan,

My gratitude might win:

He'd seen me home, put me to bed,

And even tucked me in.

Oh, what a night it must have been!-

In fact, I knew it had.

The hear I'd on me did exceed

The usual "swollen" head.

But mine (how tender Paul had been!)

Was dressed, I noticed now,

Tho' splitting-for it had been split.

Then I remembered how.

Confused a trifle were my thoughts.

That blow, struck from behind, At victory's crowning moment, too,

Might shake the strongest mind. 
But, with the instincts of a born

Philatelist, and "wide,"

I first thought when, and where, and how

Would Paul the spoils divide.

What of the splendid Privateer-

The moving spirit there?

If I were spared, then surely Fate That noble life would spare.

Of Paul, Prince of Philatelists, The. Stamp World yet would sing

The praises - and of me, the PrinceFor Paul was now the King.

And as my mental vision cleared

Passed swiftly through my brain

Grand thoughts; for I in fancy fought

My battles o'er again.

Confused at first, did memory then

Her wondrous power renew;

Passed stirring scenes before my eyes

In panoramic view.

But did I dream? A stranger stood

Before me, nor perplexed-

A lady, too, in my bedroom !

Well, 'pon my word! what next?

I tried to rise. To my surprise, Satid this audacious miss :

"You can't get up." "I cann," said I,

"If you get out of this." 
And then (what cheek do some girls have!-

This one had, anyhow)

She placed her hand-a nice soft hand-

Upon my fevered brow.

I could not well resent it, but Said, "Pray don't hurry-tho",

When finished, if you do not mind, I don't mind if you go."

She kept her place-no proper place:

Her place she did not know.

"Have you been long?-or how long here Will you be ere you go?

But hand me that newspaper, please."

(Our fight no " rag" would miss.)

She gently said, "You mustn't talk."

Then firmly said, "Drink this!"

From maid so fair, in sweet nurse garb,

No drink could one decline-

And least of all the one with head

And tongue the like of mine.

I drank-but what, I did not know.

In Morpheus' arms soon hugged

I slept. With morphia there's no doubt The drink I drank was drugged.

* $\quad$ * $\quad * \quad * \quad *$


I heard a man's voice when I woke (I kept my eyes closed, tho').

"A bad case, nurse; and he'll require A deal of pulling thro'.

He's safe, tho', whilst the breathing's free."

(I breathed with might and main.)

"Delirious been? Oh! yes; no doubt.

He may be so again.

Ah! Caught the chill while cycling-eh?

There's few these chills escape.

A 'pedaller' e'en may lose his life-

For lack of what? - a cape."

("A Cape! this sleuth-hound's from "The Yard!" "

My head began to swim.

He left, no doubt, to interview

The ghost of Pedlar Jim.)

Nurse said he came to sound me. "Yes,

I thought as much," said I.

"I heard him 'sounding' you as well.

The man's a common spy."

The patient then the nurse did "sound."

"Who's he, nurse?-I insist!"

"That's Doctor Leggie-Spydre-Webb, The famous specialist."

"Hang spies, and spiders too!" I roared.

Yet-of such stuff are We-

The ruling passion, strong in death,

Rose strong just then in me. 
All of Us would the question put That I now put direct :

"A specialist? But-tell me, nursePray what does he collect?"

Alas! nurse only dashed my hopes.

Was it her wish to tease?

"The only thing that he collects,

I think," said she, "are fees."

"A specialist, you said. P'r'aps he's

A great Philatelist?"

To my disgust she answered, "No,

A great lung specialist."

A mere collector, then, of fees:

No true Philatelist,

But one who was collecting " bills" -

A common "fiscalist."

'Twas Paul who'd brought me to this pass.

But I would make no bones

O'er any bill sent in to me,

But send it on to Jones.

* * * * * * *

My cousin Evelyn, come to "help"

Nurse Dymple-happy name!-

From Kensington arrived. As "nurse"

(And "cook") she'd won some fame. 
With scientific mind, no doubt, She merely looked upon

Myself as "something in her line"Just to be practised on.

My case, in feeding, needed care, So our old, long-tried cook

Pro tem. was superseded by

One with a cookery-book,

One who'd won fame-for Evelyn's name

First place held on the roll

Of those who'd passed with honours at

A high-class cookery-school.

Once on a birthday cake (and mine)

She did her black art try.

One swallow makes no summer-but

One "swallow" made me shy.

Tho' I forgave, I never could

Make "light" of that " affair."

Were that cake worth its weight in gold

I'd been a millionaire.

Alas! with all her science, no

Philatelist is she.

Tho' (from her pots and pans reclaimed)

She might - who knows? - yet be.

"You'll have some nice new dishes from

"The recipes I've here."

"Then find a recipe to make

My lost Stamps re-appear:" 
Stamps on the brain had I, nor cared

Tho' I had eaten horse

(Provided that coz Evelyn did

Not "specialise" the course).

When, in my ravings, "pairs" I named

She for some "Williams" sent.

"Mint" was a word she caught-and thought

Its namesake's sauce was meant.

When "Sandwiches" I raved about

(My thoughts still "far away")-

"Doctor forbids both beef and ham," My simple coz did say.

But "Missionary" marvels worked.

She to the rector ran :

"My cousin's sinking fast, and wants

To see a clergyman."

And now I could have murdered Paul,

My vengeance just to wreak-

Tho' for such violent exercise

I felt a deal too weak.

The dog had had his day, and soon

The cur would get his due.

Who but a cur could e'er have penned

This note?- - the which he'll rue:- 
"Keep up your pecker, poor old chap.

'Tis best I should not see

You yet awhile, the doctor says;

So don't, old boy, blame me.

Only arrived this morning home

(In pieces) from the war.

I've got some 'gems' of War-Stamps, tho',

Bought of a friendly Boer."

This pirate screed to "cheer me up"

Was read. I beg to state

To me 'twas clear The Privateer

Meant to repudiate.

I own that when 'twas read I used

Some words of dreadful sound,

Prefixed to trifles such as " cheat,"

And "cur," and "thieving hound."

Out of his depth in treachery

Paul waded (e'en for him).

Into the vortex all were drawn,

For all were in the swim.

"Find me the Stamps!" I fairly shrieked.

(The neighbours heard, they said.)

I made a movement (Evelyn screamed)

As if to leave my bed.

Too weak to rise, and, whilst I lay,

Of Paul was I the sport.

Put not your trust in "Princes" of

The Philatelic sort. 
"Where are the sacks of Pennies-Black That held the rare $R . V$.?"

Evelyn at nurse looked helplessly, Whilst nurse looked hard at me.

Nurse Dymple calmly said “ Keep quietQuite quiet!" Said I, " Not quite!"

(I now would be delirious-

The doctor said I might!)

Down came my fist, and down a tray

With glasses; phials, and jugs.

"Give me my Pennies-Black, and not

Your penny-farthing drugs!"

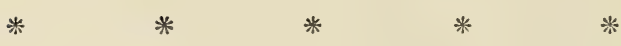

At length a welcome visitor

I was allowed to see.

Wal Waterhouse (dubbed "Watermark")-

A chum, and cute Q.C.

By him no anchor, star, nor crown

Unseen can long remain.

We say that he has " watermarks

(Not water) on the brain."

I asked for Wal. They sent for Wal,

To cheer or "humour" me.

He did both in a marv'llous way,

As presently you'll see. 
To each detail of my strange tale

Then gravely listened Wal.

I closed it with the query, "Now What do you think of Paul?"

He under cook not Paul's defence, As other Q.C.'s might.

But said, "Will, you can 'brief' me, if

You're 'wanted,' re the fight.

Paul's safe. His influence at Court

Will carry weight, and then

Th' authorities won't trouble you-

They'll fear your trenchant pen.

I'm sure, myself, that you have been

To where you say you've been.

What's more, I quite believe you've seen

The Stamps you say you've seen.

But this I say-and you'll admit

In this much comfort lies-

The Stamps that Paul has walked off with

Are all rank forgeries!"

What mind but a Philatelist's

(And that mind a Q.C.'s)

Could thus console one for the loss

Of sacks of Black R.V.'s?

Counsel's opinion far outweighed

Doctor's advice and fuss.

What comfort one derives from one

When each one's One of Us! 
The greatest of physicians in

My legal pal did call-

For blithesome Doctor Laughter is

The greatest of them all.

How roared I at the happy thought-

My very side yet aches.

Paul Jones The Privateer at large

With sacks of worthless fakes!

That was the turning-point indeed,

For my wild ravings stopped.

I soon picked up, in spite of all

The hints our doctor dropped.

That night I wanted no repose,

My mood was blithe and gay :

There was a sound of revelry

By night as well as day.

Thus laughter cured where physic failed,

Our doctor's physic's slave.

Not I-but his prediction grim

Was laid then in the grave.

"We're getting on so nicely now."

It nearly maddened me

To think of all that $I$ ' $d$ gone thro',

Then hear him speak of "We."

“ We've pulled you thro'," with pride said he. They pull that way-altho',

If thro' death's door I'd passed, would he Have said, "We pushed him thro",? 





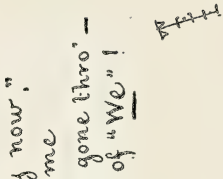

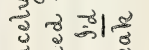

हु के क्षे

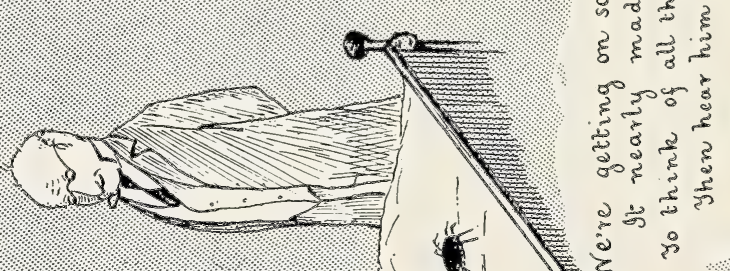

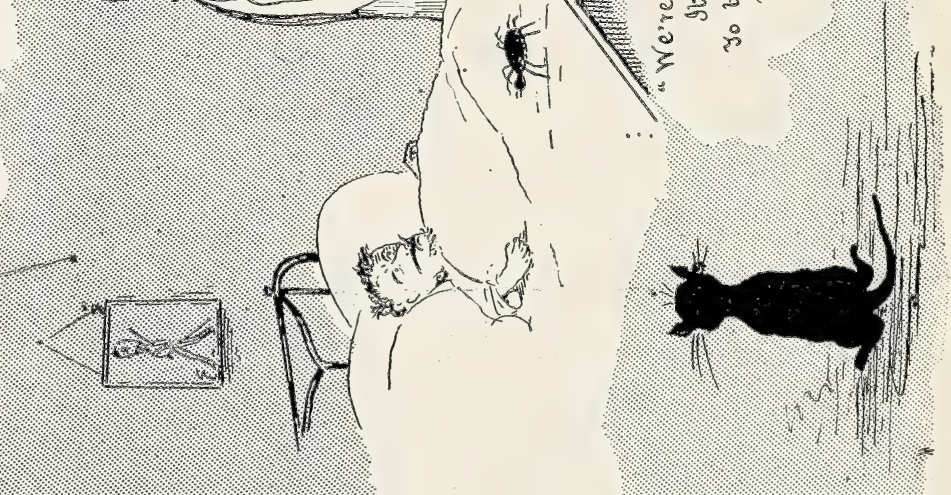


Were Waterhouse called in when I

Commenced to rave and curse,

A full-grown man, and in his prime,

Need not have had a nurse!

* $\quad$ * $\quad$ * $\quad$ * $\quad$ *

You, long ere this, have guessed the truth.

Reader, is that not so?

The prosy truth of my romance

To me came as a blow.

No Waterhouse was there to break,

With legal tact, the shock.

The bitter truth came thro' our old

(Non-scientific) cook.

She took a "turn" my bed beside.

(And gave me one forsooth!)

Thinking I slept, had nurse gone out,

And now out came the truth.

Re that " night out" the well of truth

Might sounded be, no doubt.

I " pumped"-and drew this bitter draught:

"You ain't 'ad no night out."

Cook worships me. Her truth, at least,

For want of tact atones.

"When I came home this morning, cook,

Did you see Captain Jones?" 
“'Lor, bless my soul! six days 'as gone Since you was took that queer.

It's me as found you nearly dead, Sir, in your study-chair!

That night you raved, sir, awful wild, And went and 'urt your' 'ead.

You seemed to be like fightin' when

You tumbled out of bed."

I'd won that scar of honour, then

(Did it deserve applause?),

By merely falling out of bed

In Philatelia's Cause.

Cook is a true Job's comforter,

Nor weighs what she's about.

She's quite a " character" (altho"

She came to us without).

“I 'as my doubts if you'll pull thro'.

You've knocked us all up for .

So long-because the doctor says

You was at death's front door.

It's lucky as you're 'arf alive.

They mostly don't pull thro',

With that there 'igh brain-fever when

They 'as 'ead troubles too.

They says as 'ow your lungs 'as saved

Your life, 'cos you've the best-

Which that ammonia's awful when

It settles on the chest."

* * * * * *


A dream! Then from so rare a dream

To wake indeed were pain.

In the sweet words of that old song,

O, "Let me dream again."

'Twere better far to dream and dream

(If such could be one's lot)

Of rare "finds" than to wake and find

The "finds" you found were not.

Let it go forth, then, as a dream,

A dream above all price-

A dream of rare " gems," far beyond

The dreams of avarice.

The idle dream their idle dreams;

But I, at least, it seems,

Of all Philatelists who dream,

Had dreamed The Dream of Dreams..

* * * * * * *

As in my "den's" bay=window I

One morn sat looking out

O'er Wimbledon's fair common (with

Its sea-like breeze about)

I a black steed (tho' not Black Bess)

With rider bolit espied,

Who a few minutes later on

Was seated by my side. 
Once more I felt Paul's friendly grip ; And then The Dream I told

To one who'd " held his own," but who

His sides now had to hold.

"By George!" cried he, " if only we'd

A chance of getting thro',

The things you say we did are just

The things we two would do.

But cheer up, Will : next week you're booked

For Woodblock House. That's so.

A change of air-pure Devon air-

Works wonders when you're low.

Your doctor says by Monday next

You'll stand the journey quite.

We go down à la Pullman, so

You won't be killed outright.

The mater's there with Pauline, and

We shan't be hermits, Will."

(Lily's and Flo's identity

I'd keep a secret still.)

Ah me ! to meet the peerless one

E'en now a trial would seem;

For conscience asked, "How could you prove

So false-e'en in a dream?" 


\section{XXVII.}

\section{Irove's Old, sweet Song.}

With limbs outstretched a cosy couch upon, And closing eyes, in keeping with the day,

In placid mood, and sweet thoughts dwelling on, The interesting convalescent lay.

The sanctum this of Woodblock House, and rare, 'Twas " Philatelia's Boudoir," justly named.

Its walls were graced with choice designs that fair

Skilled hands had formed (in gold they should be framed).

Flowers and rare sweet birds, whose tiny wings

Proclaimed the beauteous birds of Paradise,

Designed in Stamps (the like Our Goddess flings

Aside as trifles), formed each quaint device.

Whilst she, whose dainty handiwork mine eyes

So charmed-save when her eyes mine captive kept-

Sat at the instrument, whose ivory keys

Her hands, so skilled in art, now lightly swept.

Carsed Pauline's beauty, calm as that June night,

Within my breast a storm of love to break.

Did that sweet air suggest that dare I might

The love, in written words expressed, to speak? 
Those lines that I, at her own sweet request,

Had wedded to her favourite melody

True love inspired. Had she their motive guessed?-

Or lacked my effort crude love's harmony?

Or had I dared, maybe, to desecrate

What to the gems of melody belongs?

What lover's lines could worthy be to mate

With one of Mendelssohn's sweet wordless songs?

" Sing me the words you wrote to this old air."

Her voice, so sweet and low, my being thrilled

As, 'neath a spell, I rose, and, standing near

Fair Pauline, seemed my very heart's beat stilled.

Then to her music poured I forth the words,

I might, at least, in song my love declare;

That melody, "The Spring Song," well accords

With lover's mood when played by one so fair.

\section{THE SPRING SONG.}

I have got a secret that I fain would tell

Would but she to whom I'd speak vouchsafe some sign or token.

Would she wish to hear the secret I would tell ?-

Or would she have those words remain unspoken?

Dared I be that secred voicing,

Would she leave my heart rejoicing? 
Spoke she but one word, were I no longer sad,

My heart indeed were glad. For how could there be - sadness

If she I told my secret to both heart and secret held?

I would my heart and secret she safe in her keeping held.

* $\quad$ * * * * *

As died away the dreamy symphony

She spoke, whilst in her eyes methought did shine

Love's light. "Our thoughts are in true harmony.

A verse I've also written. This is mine:-

I, too, have a secret that I fain would tell-

One that ever haunting is my waking hours and sleeping. 'Tis a secret I to one alone could tell

Would he but trust his secret to my keeping.

Be a simple word the token-

Why should it remain unspoken?

If 'tween him and me one secret only be

Our hearts and lips were free to tell that secret freely. One simple word might prove indeed there need no secret be;

One word alone our secret prove no secret then to be."

* $\quad * \quad * \quad * \quad * \quad *$ 
I heard the voice, the sweet voice of my dream.

(No other voice shall e'er my Mentor be.)

How many a prima-donna's note doth seem

Less sweet, melodious-at least to me!

As ceased the song she placed her finger-tips

My hand within, and, in the old sweet way, Fond lips were meeting, as true lovers' lips

Will meet so long as Cupid holds his sway.

* $\quad * \quad * \quad * \quad * \quad *$

O, blithesome Doctor Laughter, you

Can now no longer claim

First place amongst physicians ; for

The greatest I can name,

Whose cure is instantaneous, whose

Prescription has no gall.

Of doctors Doctor Cupid is

The greatest, after all.

"These foolish children understand,

At last, each other, Paul,"

Said Pauline's mother when I'd passed

Safe thro' my dread "ordeal."

Jones answered, whilst my hand he gripped,

"Poor Pauline's caught at last.

But what about her future with

A 'Fiend' with such a past!" 
The Dream, which, in "strict confidence,"

I'd only told to Paul,

Was known, as far as Woodblock House

Might be concerned, to all.

Mother and sister well had Paul

Coached up the story in.

With after-dinner chat that night

Did "chaff" - and cruel-begin.

When I complained: “ Your wretched jests

- Give me, Paul, quite a chill."

The ruffian said: "Why don't you, then,

Put on the Fur-coat, Will?

- Grim's sleeping on it now, and Spi

In the 'blind' pocket's hid,

But they'll oblige ___ " "Paul, can't you see

That I'm an invalid?"

E'en the old lady fired a shot,

Without the faintest smile.

So well assumed her mock reproof

I almost deemed it real.

"I trust you'll never ask my girl

(Just think what folks would say!)

At Boar's Head smoking-concerts low

To sing, or dance, or play."

Then chimed the booby-giant in :

"He took me also, ma!"

The while he lit (the awful fool!)

An "awful full" cigar. 
E'en my fiancée spared me not, But said, in the same strain,

"It upset ma, Will, very much ;

So don't take me again."

"He'll ask "The Boer' to dinner next!"

Said Paul. (The stupid ass!)

The mater then said, "That's a thing

I really cannot pass."

To Pauline for relief I turned-

"Please sing." She asked, "What, dear?-

'The Lily O' Killarney' or

'Paul Jones The Privateer'?"

From this all-round cross-fire of " chaff"

For me seemed no escape.

"You haven't seen my latest 'find,'" Said Paul_" a blood-red Cape!"

Pressed once again to sing, Pauline

Replied, "You'll think it 'slow'-

For I've not any saucy songs

Like Philatelic Flo."

What did it mean? Could I make terms

With my tormentors three?

Some object had, I felt convinced,

Their cruel conspiracy.

And then I learned the price of peace-

A heavy price, 'twould seem :

To enter their charmed circle I

Must needs write up The Dream. 






The gentle Pauline proved the most

Relentless of the three:

She went one better, saying, "You

Must write in poetry."

No compromise-for she stood firm

Whilst I heard with dismay

That not until my book appeared

Would Pauline name the day.

* $\quad * \quad * \quad * \quad * \quad *$

The traitor Paul a mean game played

The meantime in, of course ;

For when the smokeroom's talk was Stamps

He made the fellows hoarse

With laughter loud - at my expense.

Paul's yarn, that made them scream,

He called "The Stamp-Fiends' Raid: A

Philatelic Poet's Dream."

I pleaded hard that he no more

With me would play the clown;

But all that I received was this:

"You'll have to live it down."

One consolation have I got:

Paul's known, both far and near

(Tho' he cares not), as “ Stamp-Fiend Jones,

The Famous Privateer." 
With a Stamp-Fiend's persistency

Does Paul persuade folks still

"Twas I who dragged him out that night,

And much against his will!

No matter what Paul's hearers hear

(With him rests the disgrace),

My readers have, at least, a true

Account of what took place.

* $\quad * \quad * \quad * \quad *$

Reader, farewell!-for now we part,

I trust we part as friends ;

Pardon this "pome!" You know how much The book for me portends.

For, when it's "out," a bride I win,

And, knew you that fair maid,

Methinks you'd e'en forgive the man

Who wrote "The Stamp-Fiends' Ratd."

(Finis.) 


\section{GLOSSARY OF TERMS, \&C.}

A B C.-Bright's "A B C" Postage Stamp Catalogue.

Advanced.-Denoting knowledge and excellence, as applied to collectors and collections respectively.

A. J. P.-American Journal of Philately, also Austratian Journal of Philately.

ANCHOR.-A watermark of this design appears on many postage Stamps (see Watermark).

Avery.-Mr. W. B. Avery (of the Birmingham firm of scalemakers), whose fine collection includes specimens of the rare Post Office Mauritius Stamps (see P.O.M.).

Bamra.-One of the Indian Native States.

BAzAAR.-The Bazaar, Exchange, and Mart. Its Philatelic Supplements and articles are well known.

BenthaM AND HookeR.-Joint authors of the Handbook of Bitish Flora.

Bessee - ("Bess o' Bef'nal Green.") The beautiful daughter of "The Blind Beggar of Bethnal Green," said to have been Henry, son and heir of Sir Simon de Montfort.

BILt.-Bill or Revenue Stamps are sometimes called "Bills."

Bishop.-Mr. Percy C. Bishop. A writer on Philately, and Editor of The Stamp Collector's' Fortnightly. 
BLANK.-A space to be filled, also a stamp-album in which the names of the stamp-issuing countries are omitted, the collector using his own diseretion in displaying his specimens.

BLECTÉ.-The backs of certain Stamps are sometimes found "blued" by chemical action of the gum.

BloAter.-A Stamp collector who accumulates many duplieates of any particular Stamp or Stamps.

BLOcK.-Unseparated Stamps, other than those in single pairs or strips, are described as blocks (or en bioc). An entire sheet is so called, and a half sheet a "pane."

Bluetr.-Bluett and Co. Stamp dealers.

Blue-without-lines.-The first English Twopenny Stamp shows no white dividing line above or below the Queen's head.

B. M. Trustees.-Intended for the British Museum Trustees. Brattreboro.-One of the rarest of the U.S.A. local Stamps, for which, it was said, some $£ 300$ changed hands.

BRIGHT.-Bright and Son. Stamp dealers and publishers of the "A B C" Stamp Catalogue.

British GuianA.-The two-cent rose Stamp of British Guiana (1850) is one of the "gems" of Philately.

Brown.-Mr. Wm. Brown. Stamp dealer, and publisher of The Philatelic Journal of Great Britain.

Buffalo Inverts. - Certain values of the Stamps issued to commemorate the Pan-American Exhibition at Buffalo (U.S.A.) are known with inverted centres, i.e., with the centre or "picture" portion of the design placed the wrong way up. (Such " errors," it is said, may not always be unintentionally made!)

BuHL.-Mr. Theodore Buhl. Stamp dealer and auctioneer. 
BuLL.-Ventom, Bull, and Cooper. Philatelic auctioneers, etc.

Burlington.-The Burlington Magazine, A high-class illustrated monthly for art collectors.

CAPE.-A Cape of Good Hope Stamp is commonly known as a Cape.

Castle.-Mr. M. P. Castle. A Philatelist and writer on Philately. Editor of The London Philatelist.

CAT.-An abbreviation of Catalngue.

Ceylon.—"Ceylon's first issue fourpenny" (imperforate)- the fourpenny rose-coloured Stamp of 1857, and one of the rarest "Ceylons."

Снамrba.-One of the Indian Native States.

Changeling.-A Stamp whose original colour is changed (artificially or accidentally) to another shade, or one from which the colour has faded.

CHIPS.-Book-plates of the Chippendale style (1740-1770).

Church-Corn.-The proverbial threepenny-piece.

C. J. P.-Mr. Chas. J. Phillips (of Stanley Gibbons and Co.).

Colour CHart.-A chart showing graduated shades of the various colours, to assist Stamp collectors in determining the particular "shade" of any stamp.

Compound Perforation.-When the perforations vary on the sides of a Stamp it is said to have a " compound perforation" (see Perf).

Connorsseur.-The Connoisseur. A high-class illustrated art magazine for collectors.

Copy.-Used in the same sense as the word Specimen.

CRown.-Many watermarks of the British and Colonial Stamps are in the form of a crown (see Watermark). 
CuRtis.-Mr. F. Curtis. An early collector of and writer on British Postmarks (under the pseudonym of " C. 62 ").

Daniels.-Mr. J. H. Daniels. Author of A History of British Postmarks.

Daun.-Mr. C. J. Daun. A specialist in the Stamps of the Orange River Colony, ete.

De Worms.-Baron De Worms, whose name is inseparable from Ceylon-in connection with the Stamps of that country.

Denbigh's Dandies.-Intended for The Honourable Artillery Company, commanded by the Earl of Denbigh, which numbers many marksmen.

DHAR.-One of the Indian Native States.

Dorman.-Mr. James Dorman. Book-plate dealer and expert.

Dots - In some of the overprints (V.R.I, and E.R.I.) of the Stamps of the Transval and Orange River Colony certain dots or stops are absent.

Duplex. - The pen-name of a writer on British Postmarks.

Duveen.-Mr. H. J. Duveen, who owns a fine collection of Stamps.

Earée.-The Rev. R. B. Earée. Author of Album Weeds, a work on Philatelic forgeries.

EARLy Piate.-An engraved Stamp from an early impression of the plate.

E. D. B.-Mr. E. D. Bacon. A leading Philatelist, and jointauthor of various Philatelic handbooks.

Edwards.-John Edwards and Co. Philatelic auctioneers.

E. J. N.-See Nankivell.

Emma.-A Queen of the Sandwich Islands (Hawaii), whose portrait appears on the dollar (100 cents) Stamp of 1883. 
EnTIRE. - A term applied to uncut postal stationery, such as envelopes, wrappers, and posteards (e.g., "a collector of 'entires'”).

ERroR.-Any mistake in the design, colour, inscription, ete., of a Stamp is known as an "error," and, as such, is prized by collectors.

Evans.-Major E. B. Evans, R.A. Editor of Stanley Gibbons' Monthly Journal, author of various works on Philately, and an authority on the Stamps of the Indian Native States.

Evil May-DaY.-The 1st of May, 1517. So called on account of a general rising of the London apprentices, which was directed against foreigners.

Ewen.-Mr. H. L'Estrange Ewen. Dealer in British Stamps, ete. Editor of Ewen's Weekly Stamp News.

Exchange and Mart.-See Bazar.

Ex-Libris.-A book-plate or collector of book-plates. The title of the magazine devoted to the subject.

FACE VALUE.-The postal value as denoted, in words or numerals, on the face of a Stamp.

Fake.-A counterfeit or forgery (see also Changeling).

FaKer.-One who "fakes," i.e., tampers with a Stamp with the object of increasing its Philatelic value.

Faridicot.-One of the Indian Native States.

Ferrary.-Herr Von Ferrary (M. Philippe la Renotière, of Paris). The owner of the largest and finest collection of Stamps in the world.

FieLd.-Mr. D. Field. Stamp dealer.

Find.-A discovery of or bargain in Stamps.

Fiscalist.-A collector of fiseal or bill Stamps. 
Fulu Gun.-An unused Stamp, with the original gum at the back intact, is said to have "full gum" (see Mint and O.G.).

GAUGE.-Perforation Gange. A scale of the length of 2 centimetres, for measuring or "gauging" the perforations of a Stamp (see Perf).

GEM.-A rare Stamp is sometimes described as a "gem."

Gibbons.-Stanley Gibbons and Co.'s Stamp Catalogue. “Gibbons' Nos. 17, 28," ete., refer to Stamps of any particular country, and correspond to the numbers in the Catalogue.

Grut.-Mr. L. Upeott Gill. Proprietor and Publisher of The Bazaar.

Ginn.-Mr. F. R. Ginn. Stamp dealer.

Giwelb.-Mr. F. Giwelb. Stamp dealer.

Glendining.-Glendining and Co. Philatelic auctioneers, etc.

GRILLE.-Usually a square or rectangular pattern of small dots embossed upon the Stamp. This was intended as a safeguard against the fraudulent cleaning of used Stamps.

GUM.-The adhesive substance on the back of a Stamp (see O.G.).

Gumpap.-An opprobrious term applied to a Stamp of a speculative character, i.e., a Stamp issued rather for sale to collectors than for legitimate postal purposes (vide Seebeck).

H.A.C.-The Honourable Artillery Company (see Denbigh's Dandies).

HАCKET.-The portrait book-plate of Bishop Hacket, engraved by W. Faithorne in 1670 .

HAdLOW.-Mr. W. Hadlow. Stamp dealer and anctioneer. 
HAIR-LiNe.-A finely-drawn line on the surface of the engraved plate of a Stamp. Hair-lines may be found in the corners, or angles, of many of the early British Stamps.

Hair-Splitter.-A Botanist who recognises minute varieties of the same species of plants.

Harrison.-Mr. Gilbert Harrison. A Philatelic writer.

Heaton.-Mr. Henniker Heaton, M.P. A strenuous advocate of postal reforms.

Hilckes.-Mr. H. Hilckes. Stamp dealer.

Hiscox.-Mr. W. H. Hiseox (of Stanley Gibbons and Co.).

HoввiEs.-A weekly journal for amateurs and collectors.

Holkar.-One of the Indian Native States.

Hulu.-Mr. A. F. Bassett Hull. Author of The Stamps of Tasmania.

IGLER ("Igler plate").-The earliest book-plate known (1450).

IMPERF (Imperforate).-A Stamp that is not perforated is said to be imperf.

Imperial.-Stanley Gibbons" "Imperial” Stamp album.

Invert.-A Stamp with an -inverted centre-piece (see Buffalo Inverts).

I.P.U.-International Philatelic Union.

JACs-CBook-plates decorated after the Jacobean style (17001740).

JHInd.-One of the Indian Native States.

Jones.-Mr. J. W. Jones. Stamp dealer.

KaPIolani.-A Queen of Hawaii, whose portrait appears on the 15 cents Stamp of 1882.

Kashmir.-One of the Indian Native States.

KrnG.-Whitfield King and Co. Stamp dealers and publishers of the Universal Stamp Catalogue. 
KintoRe.-The Earl of Kintore, whose collection includes rare Stamps of Mauritius and Hawaii.

LETTERs (Plate-letters).-Letters which appear in the corners of many of the earlier English Stamps.

LIKELIKE (Princess).-Her portrait appears on the one cent Stamp of Hawaii (1882).

Liliuokalani.-Ex-Queen of Hawaii, whose picture is on the two cents Stamp of 1891.

Lincoln.-Mr. Wm. S. Lincoln. Stamp and coin dealer. Publisher of the "Lincoln" Stamp album.

LIne-EngraveD.-Or taille-douce. This style of engraving. distinguishes many of the early issues of the Stamps of Great Britain.

Linseed Lancens.-A nickname of the Army Medical Staff Corps.

Limtle He AND She.- “Dresden China." One of Molloy's charming songs.

LOBSTER.-A nickname for a red-coat.

Lockyer.-Mr. Gilbert Lockyer. Author of Colonial Stamps.

L.P.-The London Philatelist. The jourual of the London Philatelic Society.

LUMPER.-A Botanist who ignores, or "lumps" together minute varieties of the same species of plants.

Marchant.-Marchant and Co. Stamp dealers.

MARGiN.-The blank edge or border round an imperforate Stamp.

Martin.-Martin, Ray, and Co. Stamp auctioneers.

Madritius.-A Stamp of Mauritius. (See also Post-Office Mauritius.)

McLEoD.- "The Lady MeLeod." A local Stamp of Trinidad, issued by the Lady McLeod Steam Navigation Co. (1847). 
Mekefi's Weekly Stamp News.-A popular Philatelic journal (St. Louis, U.S.A.).

Mendoza.-Daniel Mendoza. A Jew pugilist, who held the belt at the close of the 18th century.

Mint.-A Stamp unused and in perfect condition is described as "mint."

Missionary.-The first Stamps of Hawaii (1851) have been called the "Missionary" issue. They are great rarities.

M.J.-Stanley Gibbons' Monthly Journal. A Philatelic magazine.

MorLey.-Mr. Walter Morley. Dealer in British Postage and Fiscal Stamps. Publisher of Morley's Philatelic Journal.

Mount.-The gummed hinge by which a Stamp is affixed to the album.

Mountaine.-R. Mountaine. An engraver of Chippendale book-plates (1745-1755). Specimens of his work are known as "Mountaines" or "R.M.'s."

Mulready.-The Mulready Envelope, designed by W. Mulready, R.A. (1840).

Myerscough.-A. Myerscough and Co. Stamp dealers.

NANkivelL.-Mr. E. J. Nankivell. A specialist in Transvaal Stamps, \&e. Editor of The Philatelic Record.

NAPIER.-Lieutenant F. H. Napier, R.N. Collaborator (with Mr. E. D. Bacon and others) in various Philatelic handbooks.

NePaul.-One of the Indian Native States.

Nevis.-Stamps of Nevis overprinted "Saint Kitts"

(St. Christopher) are revenue Stamps.

Nissen..-Charles Nissen and Co. Stamp dealers. 
Non-Adhesive.-A term applied to such Stamps as are embossed or printed upon envelopes, wrappers, \&c.

N.S.L.-The Numismatic Society of London.

Numerals.-The early Sandwich Islands Stamps have a large numeral of value, and are sometimes called the "Numeral", issue.

O.G.-With the original gum intact.

OLIver.-Mr. F. H. Oliver (of the firm of Bright and Son).

O.R.C. (Orange River Colony).-These letters were overprinted on the Stamps of the Orange Free State at the time of the British occupation.

Original. - Stamps on the original envelope, cover, or wrapper are described as being "on original," or "on piece of original," as the case may be.

OvERPRINT.-Letters or words overprinted on Stamps (see O.R.C.).

OXFORD-TURNER.- " Oxford-Turner find." This refers to a remarkable "find" of Triangular Capes by $\mathrm{Mr}$. J. R. F. Turner, of Oxford.

PAIR.-Generally taken to mean two unsevered Stamps (see also Undivided Pair).

PANE.-A half sheet of Stamps.

PAPer.-Many varieties of paper are used in the manufacture of Stamps, such as wove, laid, pelure paper, \&c.

Peckitt.-Mr. W. H. Peckitt. Stamp dealer.

Penberton.-The late Mr. E. L. Pemberton. One of the best known authorities on Philately.

Pemberton.-L. P. Pemberton and Co. Stamp dealers.

Penny Black.-The first postage Stamp issued was the Penny Black English Stamp of 1840. 
Penny Red.-This Stamp succeeded the above, and was, with certain slight ehanges in design and shade of colour, in use from 1847 to 1864 .

Perf.-Perforation (or perforated). A Stamp is described as being perf. $10,12,12 \frac{1}{2}$, etc., according to the number of perfs. (see Gauge).

Periodical.-Periodical or Newspaper Stamps of the U.S.A. 1875-1895. A large remainder of these Stamps was sold by the U.S. Government in 1899 to collectors and dealers, but, as many of the higher values in the 50,000 sets offered had been reprinted in order to make up the number of sets mentioned, much dissatisfaction and disappointment resulted.

PHIL.-An abbreviation of Philatelist.

Philatelia.-The Goddess of Philately (which see).

Philatelist.-One who collects and makes a study of Stamps. Philately. - The study of Stamps. From the Greek philos, " fond of," and ateleia, "exemption from tax."

Philbrick.-Judge F. A. Philbrick. A prominent Philatelist and writer on Philately.

Picture Postcard.-The Picture Postcard. A magazine for collectors.

Picture-Set. - A set of Stamps depieting scenery, historical events, ete.

P.J.G.B.-Philatelic Journal of Great Britain.

P.J.I.-Philatelic Journal of India.

PLAte. - Denotes, in the present volume, the engraved plate of a Stamp, its plate number, or a book-plate.

Plate Number.-The number of the Plate from which certain Stamps were printed may, in many cases, be found upon the Stamp itself, e.g. the Penny-Red English Stamp of 18641880 . 
Plumridge.-Plumridge and Co. Philatelic auctioneers. P.O.M.-Post-Office Mauritius. (See below.)

Post-Office Mauritius. - The two earliest Stamps of Mauritius, the Penny Red and Twopenny Blue of 1847, are of the greatest rarity-two specimens were sold in London a few years ago for $£ 1,800$. The inscription "Post-Office" on the left-hand side of the Stamps was an error on the part of the engraver. This was altered to "Post Paid" in the subsequent issue, 1848. Hence the terms "Post-Office" and "Post Paid" Mauritius.

Pkoof.-An early, or trial, impression from an engraved plate.

Provisional.-A Stamp temporarily put in circulation.

Putrick.-Puttick and Simpson. Philatelic auctioneers, etc.

RAY.-Martin, Ray, and Co. Philatelic anctioneers.

RE-ConstruCT.-To re-construct a "plate" or sheet of Stamps, so that each Stamp be placed in the position it occupied in the sheet as printed.

R.H.G.-Royal Horse Guards (The Blues). Known also as "The Oxford Blues" and "The Blue Guards."

R.M.-See Mountaine.

Roberts.-Mr. Vernon Roberts. A specialist in Cape of Good Hope Stamps.

Rozzer (Or Rosser).-A nickname for a policeman or detective. SAFETy PAPER.-A paper intended to be proof against chemical cleaning of used Stamps.

Sale Prices.-Auction Sale Prices. Issued as a supplement to The Connoisseur.

S.C.F.-Stamp Collector's Fortnightiy. A Philatelic magazine. SCINDE.-One of the Indian Native States. 
Scotr.-The Scott Stamp and Coin Company (New York) Publishers of Seott's "Standard Postage Stamp Catalogue." SEebeck.-A term applied to certain speculative Stamps issued by some of the Central Ameriean Republic States primarily for the benefit (sic) of collectors. They are called "Seebecks" after their printer, N. F. Seebeck.

Senf.-Senf Bros., of Leipsic. Publishers of the "Senf" Stamp albums, and Catalogue.

SHADE.-A term used in describing the degree of colour of a Stamp.

Shafts or Pole.-The Transvaal Stamps issued in 1894. showed a Boer waggon with shafts. This "error" was rectified, and in 1895 the waggon was rightly represented with a pole, or disselboom only.

Sheet.-See Pane.

Shielts.-Mr. H. Ross-Shiells. Stamp dealer.

SkinnER.-Book-plates engraved by J. Skinner, of Bath (17351760 ), are commonly known as "Skinners."

Sмгтн.-Alfred Smith and Co. Stamp dealers.

Sмгтн.—G. Hamilton-Smith and Co. Stamp dealers.

Sмгтн.-Mr. Gordon Smith. A writer on Philately.

Sотневч.-Sotheby, Wilkinson, and Hodge. Art and literary auctioneers, etc.

Spectalised Coldection.-A collection confined to the Stamps of any particular country, or group of countries, and in which the most minute varieties of the same Stamps are included.

Specialist.-A collector who "specialises." (See above.)

Spink.-Spink and Son. Dealers in coins, medals, ete.

Stamp Collector.-The Stamp Collector. A monthly Philatelic journal. 
Stamp Fiend.-A term applied to those who are very keen (it may be too keen !) in the pursuit of their hobby.

Stamps.-A Philatelic journal of that title.

STAR.-Radiated marks of various design are employed for watermarks. (See Watermark.)

STRIP.-Three or more Stamps in a row, undivided.

Strong IN ENGLISH.-Having a good collection of the Stamps of Great Britain.

Substituting Fiend.-One who "substitutes" a "poor," or damaged, copy for a finer specimen of the same Stamp from another's collection.

SuRChARGE.-A printed or written inseription on the face of a Stamp, to denote a reduction in, or increase of, its original postal (or face) value.

SWAP.-To exchange specimens; such exchanges, and the Stamps so exchanged, are sometimes called "swaps."

TAILLE-DoucE.-Stamps printed from engraved plates are described as line-engraved, or as being engraved in tailledouce.

Tapling.-The late Mr. T. K. Tapling, M.P., who bequeathed his unique Stamp collection to the British Museum.

TASMAN.-A Stamp of Tasmania.

Tiffany.-Mr. John K. Tiffany. Author of The Stamps of the United States.

Tin-Belly.-A nickname for a cavalry-soldier wearing the cuirass.

TRIANGLE.-Certain triangular overprints on some of the Stamps of Peru are known as "triangles."

Triangular. - The three-cornered Stamps of the Cape of Good Hope are sometimes called "Triangular Capes." 
Tribunal. - " The first Tribunal in the land," intended for the expert Committee of the London Philatelic Society.

Two-Cents Blue Hawair.-This, and the thirteen cents Stamp of the same issue (1850) are two of the great rarities.

Two-Shilling Brown.-One of the rare English Stamps (1880).

Two-Two-Five (225).--The last printed of the Penny Red series of English Stamps were from this plate. It is one of the rarest plate numbers (see Plate Number).

Uncertain Countries. - Those countries the Stamps of which are regarded with donbt or suspicion by collectors, i.e., are not considered to be a good investment.

Undivided Pair.--See also Pair. Apart from Stamps, this term has been applied in connection with Philatelists who are about to enter (or who may have already entered) the married state.

Ventom.-Ventom, Bull, and Cooper. Philatelic anctioneers, ete.

VineR.-Doctor Viner. A very early collector of Postage Stamps, who has been called "The father of Philately."

VIRGIN.-A Stamp of the Virgin Islands.

V.R.I.-Overprinted on the Stamps of the Transvaal and Orange Free State when the Republies were annexed by the British. Some of the dots or stops were omitted after the letters. (See also Dots.)

V.R. Penny Black.-The Black Penny English Stamp, but with the letters V.R. in the upper corners in place of the ornaments that appear in the ordinary Black Penny. The V.R. was intended for official use. Its catalogue value is about $£ 10$. 
WANT.-Any particular Stamp for which a collector may be on the look out. "Wants-list"- - list of Stamps "wanted."

WARDEN.-Mr. G. C. Warden, jun. A Philatelist and authority on British Postmarks.

War Stamps.-Such as the "Mafeking Siege Stamps" (or "Baden-Powell's"), etc., etc.

WATERMARK.-A design in the substance of the paper upon which Stamps are printed. (See Anchor, Crown, etc.)

Westoвy.-Mr. W. A. S. Westoby. An anthority and writer on Philately.

White.-Mr. H. J. White, who owns a fine collection of English Stamps.

Woopblock-CAPE.-The Cape of Good Hope Stamps issued in 1861 were printed locally from woodblocks, and are known as "Woodblock" Capes. Two "errors" erept in in this issue, the $4 \mathrm{~d}$. Red and the 1d. Blue. Both these "errors" are highly prized by collectors, and very big prices have been paid for them. 


\section{Rare Postage Stamps}

BOUGHT, SOLD, AND EXCHANGED BY

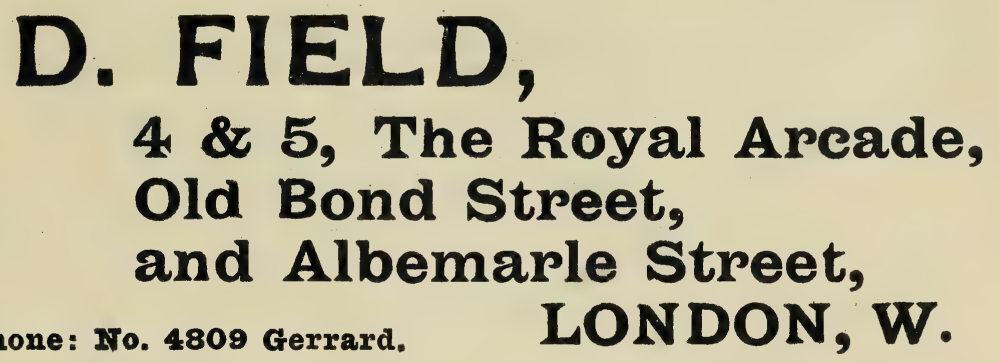

Mr. D. FIELD invites Collectors to an inspection of his unique stock of Postage Stamps, ranging from the most ordinary varieties and the newest issues to the greatest rarities.

\section{S PECI A C INY :}

COLLECTIONS AND SINGLE RARITIES OF FINE ENGLISH AND BRITISH COLONIAL POSTAGE STAMPS.

APPROVAL.-Selections of choice stamps sent on approval to responsible Collectors furnishing satisfactory references. Prices are moderate, and will compare favourably with those of any other firm.

Collections made to order from $£ 10$ to any amount.

\section{THE "ROYAL" PHILATELIC ALBUM.}

Interchangeable, superior hand-made paper, each leaf backed with Japanese tissue, 72 leaves, half-bound morocco. Price 25/. Post Free, 26/3.

Interchangeable, bound full morocco, a handsome album. Price 42/.. Post Free, 43/3.

The Most Perfect Album Published.

Every leaf is movable, and the great feature of this up-to-date album is, that the leaves are retained perfectly rigid by an improvement in the mechanism.

Finest English make, published by D. FIELD.

Wanted to purchase, Important Collections and Rare stamps, especially Great Britain and Colonies. 


\section{MORLEY'S PHILATELIC JOURNAL. Edited by L. W. FULCHER, B.Sc.}

A Monthly Illustrated Journal for Collectors of Fiscal, Postage, Telegraph and Railway Stamps. Subscription 2/6 per annum.

Specimen eopy sent Free on request.

\section{PRICED CATALOGUES.}

Morley's Great Britain (Postage, Fiscals, Telegraph, Railway, Post Free. Entires, News Tax, Deeds, \&c., \&c, ), 190 pages ... $\quad$... $\quad$ 2s. 6d.

Morley's Revenue Stamps of British Colonies... $\quad . . \quad \ldots \quad$ 2s. 6 d. Lundy's Germany and Switzerland Revenues ... ‥ ... $\quad$ 1s. 6d.

Revenue Sta ups of Spain and Colonies, including the American

Occupation, and Revolutionary issues. 100 pages quarto, on fine art paper. 325 Illustrations, bound in cloth ...

Morley's Telegraph Stamp 4 of the World, 400 Illustrations, bound in cloth

\section{GREAT BRITAIN (POS AGE).}

1d. black 1840-fine used copies, 6d. each. Pairs 2s. 6 d. $2 \mathrm{~d}$. blue $, \quad, \quad, \quad 2 \mathrm{~s} .6 \mathrm{~d}$. , , , 5s. $6 \mathrm{~d}$.

Officials-Admiralty, Army, Board of Education, Government Parcels, I.R. Official, O.W. Official. Snt of 24 varieties, used

\section{TELEGRAPHS}

6s. $6 d$.

Set of 10 of the Private Companies' Stamps (prior to Government taking the lines over in 1870), "English and Irish," "British and Irish," and "Bonelli's Electric" ...

Set of 5-"The Electric Telegraph Company," "United Kingdom Telegraph Company," "Universal," "London District"

\section{$\cdots$} .

\section{COLLEGE STAMPS}

(UsEd BY THE VARIOUS COLleges, 1871-1875).

Set of 5-"All Souls," "Exeter," "St. John's" (Oxford), "St. John's" (Cambridge), and "Selwyn" ... ...

10s. 0d.

\section{FISCALS.}

Set of 130 varieties of the Revenue Stamps of England, Scotland, Ireland, and the Isle of Man, inoluding many scarce

\section{WALTER MORLEY, \\ 15, Brownhill Gardens, Catford, S.E. . \\ Guld Medal, Parris L'xhibilion, 19J0. Ilighest $\Lambda$ ward for l'ișcil s'stampz̈.}




\section{E I I I IF PACKET COLLECTIONS . BRITISH COLONIAL STAMPS,}

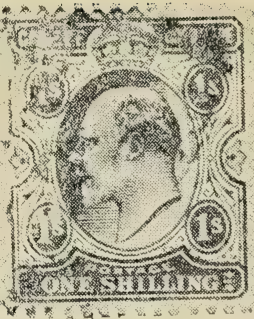

150 Varieties of Colonies in America . . . 15s.

150

150

150

",
in Africa . . 15s. ", in Asia and Europe 15s. ," in Australasia . . 15s. Postage Free.

Or the Four Parts, containing 600 picked used and unused British Colonials, for 57s. $6 \mathrm{~d}$. ALL FINE COPIES.

THE 1904 "POPULAR" BRITISH AND BRITISH COLONIAL PRICE LIST.

Over 300 Illustrations.

The most useful and compact Catalogue of British Colonial Stamps published. Ready about Dec. 1.

PRICE 3d., POST FREFE. ORDER NOW.

\section{口TIFE}

\section{PHILATELIC JOURNAL OF GREAT BRITAIN.}

A MONTHUY ILLUSTRATED JOURNAL。

Subscription 2/6 per annum, post free to any part of the World. Specimen Copy Free.

P. L. PEMBERTON \& CO., 229, HIGH HOLBORN, LONDON. 


\section{THE UNIVERSAL STANDARD CATALOGUE OF THE POSTAGE STAMPS OF THE WORLD.}

FOURTH EDITION, 1903-4.

With 3000 ILLUSTRATIONS.

\section{Price 1/3, Post Free Anywhere.}

Interleaved Edition, Bound in Cloth Gilt, $3 / 6$ post free.

This is the Ideal Catalogue for the general Collector, as only standard varieties are included; minor varieties and sizes of perforation are wholly ignored.

\section{ARRANGEMENT STRICTLY ALPHABETICAL.}

NOTE.-The Fifth Edition will be published at the end of 1904, but we hope to publish a Supplement to the Fourth Edition early in 1904, of which due notice will be given.

64. Page List of over 1500 different sets and packets of stamps, sent on receipt of penny stamp for postage.

\section{MONTHLY LIST OF PHILATELIC NOVELTIES, 6d, per annum, post free.}

Books of stamps of any colony or country sent on approval on receipt of satisfactory references.

TO THE IRADE.-Complete Wholesale List published every alter. nate month, and sent gratis and post free to bona-fide dealers. Weekly Trade List of Novelties and Bargains 2/6 per annum, but subscriptions must expire at the end of a year.

Best and Most Reliable Service of New Issues,

\section{WHITFIELD KING \& CO., IPSWICH.}

Eistablished 1869, 
Advertisements.

\section{W. HADLOW,}

Stamp Auctioneer and Dealer, 12, ADAM STREET, STRAND,

London, W.C.

\section{VALUATION FOR ALL PURPOSES.}

STAMP AUCTIONS AT REGULAR INTERVALS. Terms io per cent. inclusive.

$M^{R . ~ H . ~ h a s ~ h e l d ~ o v e r ~} 200$ Stamp Sales, and these Sales, being attended by most of the Leading Collectors and Dealers, are an admirable medium for the disposal of collections and loose parcels of stamps.

Bankers: LONDON AND COUNTY BANKING COMPANY, Ltd, Strand Branch.

\section{STAMPS BOUGHT, SOLD, AND EXCHANGED.} Advances if required.

Sole OfFICE: 12, ADAM STREET, STRAND, W.C. 
Advertisements.

MARTIN, RAY, \& Co.,

Philatelic Auctioneers,

LONSDALE CHAMBERS,

Chancery Lane, W.C.,

HOLD STAMP AUCTION SALES FORTINIHTLY THROUGHOUT THE SEASOU.

Single Specimens, Books of Stamps and Collections received for inclusion.

\section{TERMS 10 PER CENT, ON AMOUNT REALLSED}

PROMPT SETTLEMENT.

Catalogues post free on application. 


\section{SPECIALITY. \\ HIGHEST CLASS STAMPS.}

JElinest Stocls.

Olnoicest Colpies. CHEAPEST PRICES.

Thousands of Bargains in 0ld British, Culonial and For -ign Stamps.

Beautiful approval selections. Only fine specimens sent out.

Discount 25 per cent. to 50 per cent. off Catalogue Quotations.

Serious Collectors and Large Buyers can save many pounds by writing

\section{FREDK. R. GINN,}

STAMP EXPERT, DEALER \& PUBLISHER, 143, Strand, London, W.C.

Information on all Philatelic Matters and Expert Advice gladly given to all Customers.

\section{Special Offers.}

\section{A GENUINE ORIGINAL TRIANGULAR CAPE OF GOOD} HOPE STAMP. Only 2s, post free.

FULL SET OF TRIANGULAR CAPE OF GOOD HOPE 1d., 4d., 6d, and 1s.; fine copies. Only $27 \mathrm{~s}$., post free.

These stamps are of special interest to all readers of this work, and the possession of them will prove a source of pleasure, and a most profitable investment. There are no stamps which show such a steady advance in value as these unique issues.

EVERY OTHER VALUE AND VARIETY IN STOCK ÁT LOW PRICES. 
ESTABLISHED 1900.

THE COLLECTORS'

PUBLISHING COMPANY,

PUBLISHERS OF AND DEALERS IN

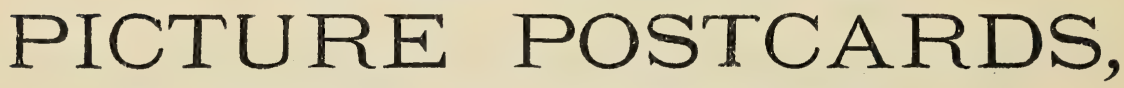

AND AGENTS FOR AIL THE BEST BRITISH POSTCARD HOUSES

SPECIALTTIIS: :-POST-CARD ALBUMS, CABINETS, CASES, FRAMES, STANDS, POCKET-PENS, and OTHER ACCESSORIES.

PUBLISHERS AND PROPRIETORS OF

THE

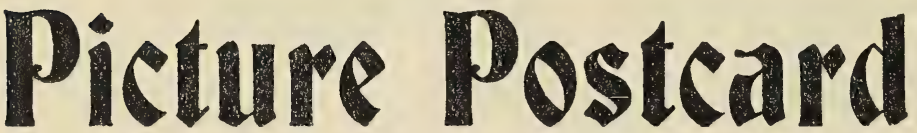

AND
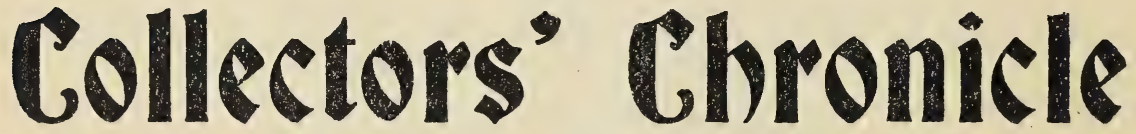

FOURTH YEAR. AGAIN ENLARGED?

The First and only English Journal devoted solely to Picture Post-cards and Kindred Subjects, such as HOLIDAY TRAVEL, POPULAR PHILATELY, and EVERY-DAY ART.

A Bright Illustrated Monthly Magazine of the Greatest Use

TO ALL INTERYSTED IN PICTURE POST=CARDS.

Price 3d. monthly, or $4 \mathrm{~s}$. a year post free anywhere, or through the usual trade channels.

CUSTOMERS OWN POST-CARDS A SPECIALITY.

The Collectors' Publisking Co.,

42 and 43, IMPERIAL BUILDINGS,

Ludgate Circus, LONDON, E.C. 


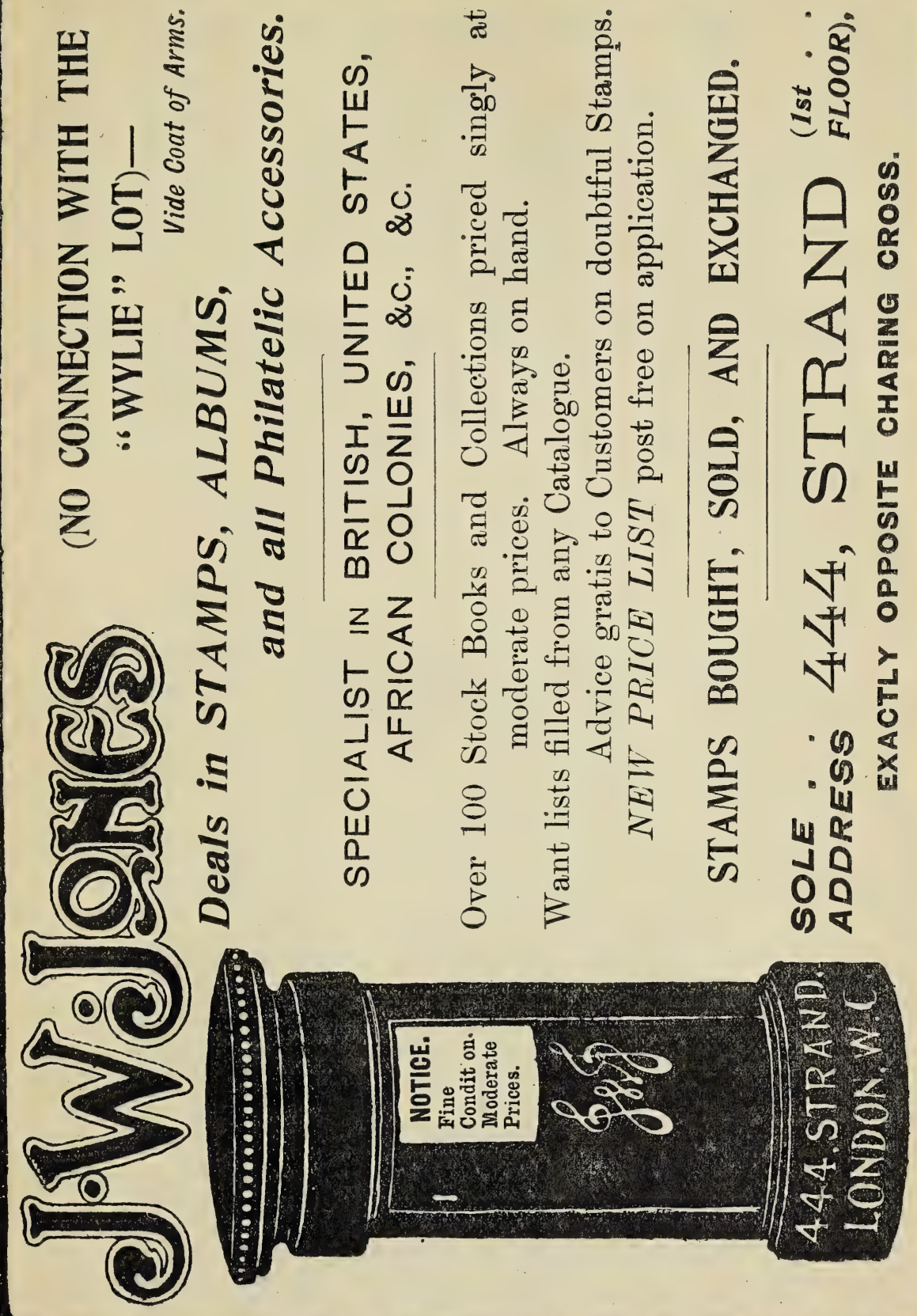




\section{GEORGE CALLF \& CO.,}

\section{Dealers in British, Foreign, and Colonial Stamps,} Established 1877.] SEAFORD, SUSSEX,

[Established 1877

Hold one of the Finest Stocks of OLD ISSUES in England. Every Stamp sold by us is guaranteed genuine. Now ready for inspection;. 100 new Stock Books (Old Issues only), pricing up to over $£ 20,000$, every Stamp in the finest condition, and priced low. Any Book sent on approval against first-class references.

Early Australians a Speciality.-We have a large stock of Sydney Views, 1d., 2 d., and 3d. Laureated Head, N.S.W., 1d., 2d., 3d., 6d., and 8d. Registered N.S.W. and First Issue Tasmania. Most of the above are numbered for plating.

West Indians, used and unused; a special collection in eight volumes, valued at about $£ 200$ ', priced low. Also special collections of Cape of Good Hope, containing over 1100 Triangular, including blocks and pairs.

Persian Stamps, all issues. Collectors interested in this country should write for a selection. We hold the finest stock in England.

Rarities, ranging from $£ 2$ to $£ 40$ each. A very fine lot on view.

We have a lot of books for beginners and medium Collectors : plenty of bargains. Lists of Wants solicited. Special selections of any country made up and submitted with pleasure. Price List of Packets, Sets, and single Stamps free.

WHOLESALR DEPT.-Owing to the great increase in our Retail Trade, we have decided to SELL OFF the whole of our stock. Dealers and Investors desiring wholesule lots will please write to us early.

STAMPS BOUGHT, SOLD, AND EXCHANGED.

Established 1887.

A. BOUCARD,

Established $188 \%$.

DEALER IN FINE STAMPS,

368 , STRA N D, IONDON, W.C.

SI F IAX, OFIERS.

British Guiana 1881 , ] c. on 12 c., lilac, S.G.N. 114. Complete sheet of 40 , with full margins, Mint, £20.

I itto 1882,1 c. crimson, complete sheet, rare setting, $3 \times 4$, unused, $£ 710 \mathrm{~s}$.

Iiberia 1 \& 9 , 1 c. to $\$ 5$, in imperf. pairs, very rare, $£ 20$

Ditto dito, surcharged official ditto $£ 20$.

(Only ten sets of these stamps were ever issued.)

Write for Lists, post free. Just published, list of over 300 Colonial Sets, and 200 Non-Colonial. from 2d. upwards

Highesi prices paid for Collections and loose lots of unused or used stamps.

In demy 4to., bound in cloth; bevel" boards, price 10s. 6a. net.


CONTAINING

Articles and Illustrations, Reprinted from the "Queen "Newspaper, of

Interest to the Great Body of Collectors, on

China, Engravings, Needlework Pictures and Embroidery, Old Silver, Brass, Pewter and Pinchbeck, Miniatures, Egyptian and Grecian Antiquities, \&c.

Beautifully Printed on Art Paper, with Coloured Frontispiece.

Edited by Ethel Deane, Editress of the "QueEn."

London Horace Cox, the "Queen" Office, Windsor House, Bream's Builụings, E.C. 


\section{GIWELB, DEALER IN BRITISH AND FOREIGN STAMPS.}

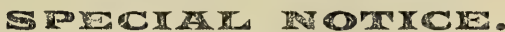

Having accumulated a large stock of carefully selected fine Stamps, I am in a position to supply the best goods at lowest prices. A trial order will convince everyone of the fact of this statement. Beginners should apply to me for a selection of my cheap sets of stamps, while more adranced Collectors are invited to ask for my specially made up Books of Stamps of all countries. Lists of wants receive special and prompt attention.

Applicants not as yet known to me will kindly furnish me with a reference. Address all communications to

M. GIWELB,

4. NORTHUMB ERLAND AVENUE, LONDON, W.C., ENGLAND.

\section{K. BROSNAN,}

Dealer in Postage Stamps and Book Plates (Ex. Libris), 27, New Oxford Street, London, M.C.

\section{ESTABLISHED 1888.}

(0pposite Mudie's Library, and near Central London Railway, Museum Station.)

\section{STAMPS A 50 PER CENT. DISCOUNT.}

have a nice lot of Books ready to be sent out on approval. Each Stamp s priced separately, and is in fine condition. As a rule, they are priced at catalogue prices, but in numbers of cases the prices are considerably less, so that with the discount of 50 per cent. allowed the prices are extremely low, and Collectors should give these Books a trial.

$$
\text { REFERENCES REQUIRED. }
$$

Fiscals and IFevemues rought for cash.

$$
\text { JOHN JAMES COATES, }
$$

4, Southwark Street, London Bridge, London, S.E.

\section{1/- A GOOD PACKET OF COLONIAL STAMPS 1 .}

The following 52 different Stamps for 1s.: Northern Nigeria, Niger Coast, Montserrat, st. Christopher, St. Vincent, Bermuda, 3 Barbados, 4 Guiana, 8 Cape, Sierra Leone, Grenada, 2 Ceylon, Gold Coast, 5 Jamaica, 3 Hong Kong, Leewards, 4 Mauritius, Newfoundland, Orange State, Perak, Selangor, 3 Straits, Transvaal, 5 Trinidad.

The entire lot 1s. post free.

\section{MYIESCOUGII \& CO., 3, BROADWAY, LUDGATE HILL, LONDON.}

Price List of Colonials Post Free Prices are very low, Wholesale and Retail. $\mathrm{X}$ 


\section{THE

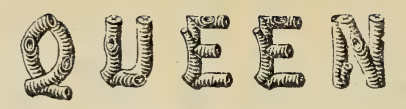 \\ THE LADY'S NEWSPAPER.}

Published every Saturday, price Sixpence.

LEADERS

A RE given every week on current and $A$ interesting topics.

\section{"GAZETTE DES DAMES"}

CHRONICLES all events of special in. 4 terest to ladies. It also contains correspondence on the social subjects that are within the province cif women.

"MUSIC AND MUSICIANS"

TREATS of all the Musical Societies, the Operas, and the new Vocal and Instrumental Music.

\section{"THE DRAMA."}

NRITIQUES of all Performances at the London Theatres, Theatrical Gossip, $\& c$.

PORTRAITS AND BIOGRAPHIES

$\bigcap^{\mathrm{F}}$ the moth men and women, of the past and present ages, are frequently given.

THE "WORK TABLE"

S devozed to designs and descriptions of all new and useful work. Ornamental Feather Work, Fretwork, Solid Wood Carving, Church Embroidery, Crochet, Tatting, Leatherwork, Knitting, \&c., \&c., are all fully treated.

\section{"PASTIMTS"}

TNCLUDE Acrostics, Croquet, Chess

1 Acting Charades, \&c., \&c.

\section{THE BOUDOIR}

IS set apart for Notes and Queries on Etiquette and such-like.

NOTES AND QUESTIONS,

WITH their Answers, on every subject W relating to Ladies, will be found in their respective departments.

COLOURED FASHION PLATES

A RE given gratis with THE QUEEN of $A$ the first Saturday of every month.

"THE PARIS FASHIONS"

GIVES Illustrations and Descriptions $T$ of the Dresses worn in Jaris at the Promenades, Balls, Fetes, and elsewhere.

C "THE TOURIST"

UIVES account of Travel and Places.
"CACSERIE DE PARIS"

IS a weekly letter from Paris, giving all the chit-chat and doings of that city.

"THE COURT CHRONICLE"

GIVES all the fashionable movements at home and abroad.

"THE LIBRARY TABLE"

GIVES reviews of the New Books, G Literary, Artistic, and Scientific Gossip, Notes and Queries about Authors and Bonks, \&c.

$A^{\text {LL the NEW MUSIC is noticed. }}$

\section{LETTERS}

FROM Paris and Vienna, with Notes f from Scotland, Ireland, and elsewhere, are given weekly.

“THE GARDFN"

TS a column set apart for instructions for Ladies' Gardening.

“ THE HOUSEWIFE,

GIVES practical instructions for the $G$ management of a household, useful and valuable recipes for cooking, preserving, pickling, \&c. \&c.

EMBROIDERY, CROCHET, AND TATTING

$A^{R E}$ all treated by Ladies well qualified ton do son.

THE NEW BOOKS

THAT would be likely to interest Ladies are carefully reviewed.

HOME DECORATION,

$\mathrm{F}^{\mathrm{XHAUSTIVELY}}$ treated by experts.

THE DOINGS OF THE UPPER

TEN THOUSAN1)

$A^{\mathrm{T}}$ Home and Abroad are chronicled.

\section{“THE EXCHANGE"}

TS a department of THE QUEEN that 1 enables ladies and others to procure articles that they want for those for which they have no further use. Crests, Monograms, Seals, Stamps, Feathers, Coins, Objects of Art or Vertu, Patterns, Jewellery, or, in short, any of those multitudinous articles that interest, or are of use to, ladies, are readily disposed of.

\section{Coloured Supplements and Chromo-Lithographs are frequently given.}

SubscRIPtion : Quarterly, 7s.; Half-Yearly, 14s.; Yearly, £1 8s.

OFFICE : WINDSOR HOUSE, BREAM'S BUILDINGS, E.C: 


\section{THE FIELD}

\section{THE COUNTRY GENTLEMAN'S NEWSPAPER.}

\section{Published every Saturday, price Sixpence.}

LEADERS

$\cap \mathrm{N}$ interesting Sporting subjects are given every week in THE FIELD.

\section{" COURSING,"}

DEPRT's of all Meetings are given weekly for the duration of the season.

\section{"SHOOTING"}

CONTENTS: Origina! Articles and Correspondence on Shooting Adventures, Game Preservation, New Guns, Cartridges, and all the paraphernalia of a sportsman.

\section{" A NGLING."}

ATICLES and Correspondence on A Fishing, Reports from the Rivers, Fish Preservation and Culture, and all matters connected with river, lake, or sea fishing.

\section{“ HUNTING,"}

DSCRIPTION of Hunting Countries, 1) reports of Runs with the various Packs of Hounds, Hunting A ppointments, Visits to the Kennels, Notes from the Shires, čc., are given during the season.

\section{"THE TURF"}

REPOR'TS of all the principal Race and $\mathrm{R}^{\mathrm{E}}$ steeplechase Meetings are given, to gether with Notes and Anticipations on Future Events, Sales of Blood Stock, \&c.

" DOGS AND HORSES."

RTICLES and Correspondence on the above subjects, Reports of Horse and Dog Shows, \&c.

\section{“THE VETERINARIAN"}

GIVES full and practical instruction for $G$ the management of Cattle in health and disease.

\section{“THE COUNTRY HOUSE,}

TNDER this heading will be found Articles, Notes, Queries, \&c., on all Subjects and Inventions that concern the Country House.

\section{"POULTRY AND PIGEONS."}

A RTICLES on their management, acA counts of Pigton Races, \&c.

\section{"BICYCLING AND TRICYCLING."}

BEPORTs of the principal Races, $\mathrm{R}$ Descriptions of New Machines, Ac. counts of 'Tours, \&c.

\section{A CHESS PROBLEM}

IS given constantly, with annotated Games, and Chess news.
"GOLF."

EPORTS of Golf Contests, Descriptions of Links, de.

\section{"A RCHTRY"}

LL the principal Matches throughout $A$ the United Kingdom are reported during the season.

\section{"LAWN TENNIS."}

REPORTS of all the principal Matches $R$ and Notes on the Formation of Courts, \&c.

$$
\text { "SWIMMING." }
$$

FULL REPORTS of all the principal Contests of the Season.

\section{"YACHTING."}

RTICLES on Yacht Building, Reports A of Matches, Accounts of Cruises, Correspondence, Yacht Intelligence, \&c.

\section{"ROWING."}

DEPORTS of Matches and Regattas, $\mathrm{R}^{\text {Articles on Training. }}$

"ATHLETIC SPORTS"

A RE fully reported every week during the season.

"FOOTBALL."

REPORTS of Association and Rugby R Matches during the season.

\section{“ CRICKET,"}

FULL and accurate Reports of all F Matches of interest are given during the season.

"TRAVEL AND COLONISATION" CONTAINS Articles upon Exploration $U$ in little known parts of the world, their capabilities for colonisation, stockraising, sport, stc.

\section{"THE FARM,} G management of Farms (both arable and pasture) and Farm Stock, Reports of Agricultural Shows, Sales of Shorthorns, \&c.

\section{“THE GARDEN”}

PRACTICAL instruction for laving out and managing Flower and Kitchen Gardens, Grape Houses, Orchard Houses, Forcing Beds, \&c., are given.

$$
\text { "CARDS." }
$$

WHIST Hands illustrated by " Caven. dish," with Notes on other Games.

Also Articles relating to "THE NATURALIST," "FOREIGN FIELD SPORTS," "RACQUETS," "BILLIARDS," \&c., \&c.

:SUBSCRIPTION-Quarterly, 7s.; Half-Yearly, 14s.; Yearly, \&1 8s.

חFFICE : WINDSOR HOUSE, BREAM'S BUILDINGS, E.C. 


\section{G. HAMILTON=SMITH \& CO., Stamp Dealers and Philatelic Publishers,}

10, BishopsGate STREET WITHIN, LONDON, E.C. Telegraphic Address: "Philatelic, London." Telephone: No. 5596 Avenue.

\section{APPROVAL OOKS.}

We hold a very fine Stock of USED and UNUSED STAMPS (20,000 Varieties), arranged in nearly 200 large APPROVAL BOOKS.

The condition of the Stamps is exceptionally fine, and the prices reasonable. Selections of any Country will be gladly sent on approval to responsible applicants.

\section{6 "IWTERCHAMGEABLE PHILATELIC ALBUMS."}

We have much pleasure in announcing that we have received

\section{A MEDAL WITH DIPLOMA}

(this being the only Award given for Permanent Philatelic Albums alone) at the International Philatelic Exhibition, held in Mulhausen, Alsace, this Summer.

We shall be pleased to forward Illustrated Prospectus of the above on Application.


1\%, Argyll Street, Oxford Circus London, W. AUCTIONEERS AND VALUERS OF Coin ollections. Medal Collections. Postage Stamp Collections.

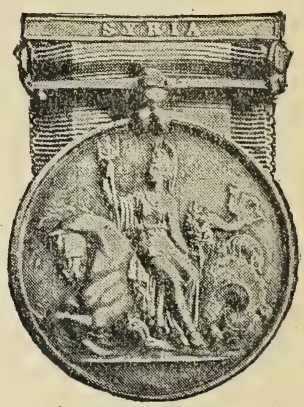
Old China. Engravings. Antique Property of all kinds.

\section{FREQUENT SALES ARE HELD OF}

FINE ART, FOREIGN STAMPS, COINS, AND MEDALS.

Dates on Application.

Our Auction Galleries are Open Daily for the reception of Fine Art Property, Jewellery, Silver Plate, Coins, Medals, Postage Stamps, Antique China, Libraries, Miniatures. Pictures, \&c.

Small or large consignments Catalogued and submitted for Sale without delay Liberal advances pending Sale if required. 



